Doktori (Ph.D) értekezés

\title{
A KAJSZI VIRÁGZÁSKORI MONILIÁS (MONILINIA LAXA ADERH. ET RUHL.) BETEGSÉGGEL SZEMBENI ELLENÁLLÓSÁGA
}

\section{Gutermuth Ádám}

Témavezető: Dr. Pedryc Andrzej, D.Sc egyetemi tanár

Budapesti Corvinus Egyetem

Genetika és Növénynemesítés Tanszék

Budapest

2013 


\section{A doktori iskola}

megnevezése: Kertészettudományi Doktori Iskola

tudományága: Növénytermesztési és kertészeti tudományok

vezetője: $\quad$ Dr. Tóth Magdolna

egyetemi tanár, DSc

BCE, Kertészettudományi Kar,

Gyümölcstermő Növények Tanszék

Témavezető: $\quad$ Dr. Pedryc Andrzej

egyetemi tanár, DSc

BCE, Kertészettudományi Kar

Genetika és Növénynemesítés Tanszék

A jelölt a Budapesti Corvinus Egyetem Doktori Szabályzatában elóírt valamennyi feltételnek eleget tett, az értekezés mühelyvitájában elhangzott észrevételeket és javaslatokat az értekezés átdolgozásakor figyelembe vette, ezért az értekezés nyilvános vitára bocsátható.

Dr. Tóth Magdolna

A doktori iskola-vezető

jóváhagyása
Dr. Pedryc Andrzej

A témavezető jóváhagyása 
A Budapesti Corvinus Egyetem Élettudományi Területi Doktori Tanács 2012. évi december 4.-i határozatában a nyilvános vita lefolytatására az alábbi bíráló Bizottságot jelölte ki:

\section{BÍRÁLÓ BIZOTTSÁG:}

Elnöke:

Tóth Magdolna, D.Sc.

\section{Tagjai:}

Palkovics László, D.Sc.

Barna Balázs, D.Sc

Deák Tamás, Ph.D

Höhn Mária, C.Sc

Opponensek:

Kiss Erzsébet, C.Sc.

Korbuly János, Ph.D.

Titkár:

Deák Tamás, Ph.D. 


\section{Tartalomjegyzék}

1 BEVEZETÉS $\quad 8$

2 CÉLKITÜZÉS

3 IRODALMI ÁTTEKINTÉS

3.1 A csonthéjasok virágzáskori moniliás betegsége: a fertőzéstől a termőrész pusztulásig 11

3.1.1 A bibe konídiumos fertőzése és a ribonukleázok gomba fejlődését gátló hatása 13

3.1.2 A megporzás hatása M. laxa bibefertőzésére $\quad 15$

3.2 Kajszifajták és rokon Prunus fajok fogékonysága a moniliás virág és vesszőfertőzésre 17

3.3 A kajszi M. laxa ellenállóság növelésére irányuló nemesítési tevékenység 20

3.4 A növényi rezisztenciagének $\quad 21$

3.4.1 A növényi rezisztenciagének csoportosítása 21

3.4.2 Növényi rezisztenciagén-analógok azonosítása 23

3.4.3 Rezisztenciagén-analógok izolálása Prunus fajokból 26

3.4.4 RGA markerek kapcsoltsága növényi rezisztenciákkal 28

3.5 Poligalakturonáz-gátló fehérjék $\quad 29$

4 ANYAG ÉS MÓDSZER

$\begin{array}{llr}4.1 & \text { Növényanyag } & 35\end{array}$

4.2 Szabadföldi természetes fertőzés megfigyelése $\quad 36$

$\begin{array}{llr}4.3 & \text { Fertőzési kísérletek } & 37\end{array}$

4.3.1 Szabadföldi virágfertőzési és megporzási kísérletek 37

4.3.2 Mesterséges vesszőfertőzés 37

$\begin{array}{lll}\text { 4.3.3 Laboratóriumi kísérletek } & 38\end{array}$

$\begin{array}{lll}\text { 4.3.4 Mikroszkópos vizsgálatok } & 39\end{array}$

$\begin{array}{lll}4.4 & \text { Molekuláris vizsgálatok } & 40\end{array}$

$\begin{array}{lll}\text { 4.4.1 DNS- alapú kísérletek } & 40\end{array}$

$\begin{array}{lll}\text { 4.4.1.1 DNS-izolálás } & 40\end{array}$

4.4.1.2 PCR-technika az NBS szekvenciák meghatározására 40

4.4.1.3 SSCP (Single Strand Conformation Polymorphism) 41 
4.4.1.4 A PCR-termékek klónozása és DNS-szekvenciájuk meghatározása 41

4.4.2 RNS-alapú kísérletek 42

4.4.2.1 Génexpressziós kísérletekhez történt mintagyüjtés 42

4.4.2.2 RNS-izolálás és egyszálú cDNS szintézis 43

4.4.2.3 Kétszálú cDNS szintézis 43

$\begin{array}{lll}\text { 4.4.2.4 cDNS AFLP } & 44\end{array}$

4.4.2.5 Poliakrilamid gélelektroforézis (PAGE) 47

$\begin{array}{lll}\text { 4.4.3 PGIP gén szekvenciájára tervezett primerek } & 49\end{array}$

4.5 Bioinformatikai vizsgálatok $\quad 49$

4.5.1 Az NBS RGA szekvenciák bioinformatikai vizsgálata 49

4.5.2 A cDNS AFLP szekvenciáinak bioinformatikai vizsgálata 50

5 EREDMÉNYEK $r \mid 51$

5.1 A kajszi ellenállóságának vizsgálata M. laxa fertőzésre $\quad 51$

5.1.1 Az ellenállóság szabadföldi bonitálása $\quad 51$

5.1.2 Virágrészek érzékenysége a kórokozóval szemben 54

5.1.2.1 A kasztrálás és megporzás hatása a virágfertőzés kialakulására 54

5.1.2.2 A bibekivonat növekedésgátló hatása az M. laxa micéliumfejlődésére 57

$\begin{array}{lll}\text { 5.1.2.3 A virágszirom M. laxa fertőzése } & 58\end{array}$

5.1.2.4 Fajták mesterséges szirom fertőzése in vitro 60

5.1.2.5 A bibe kórokozóval szembeni ellenállóképességének in vitro vizsgálata 62

5.1.3 Ellenállóság vizsgálata a 'Zard' × 'Korai zamatos' család egyedein mesterséges vesszőfertőzés alapján 63

5.1.4 A ‘Zard' és ‘Orange red’ fajták ellenállóságának összehasonlítása a fiatal levelek mesterséges fertőzése alapján $\quad 66$

5.2 Molekuláris vizsgálatok

5.2.1 Eltérő fogékonyságú kajszifajták összehasonlítása NBS LRR típusú rezisztenciagén-analógok $\begin{array}{ll}\text { SSCP vizsgálata alapján } & 67\end{array}$

$\begin{array}{lll}\text { 5.2.2 A kajszi NBS LRR RGA-k filogenetikai vizsgálata } & 73\end{array}$

\subsection{A 'Zard' és 'Orange Red' fajták vesszőfertőzésének transzkriptomikai vizsgálata cDNS-AFLP} technikával

$\begin{array}{lll}\text { 5.3.1 A TDF-ek homológia alapján történő azonosítása } & 78\end{array}$

5.3.2 PGIP gének szekvenciáinak meghatározása 80

6 EREDMÉNYEK MEGVITATÁSA 
6.1 Kajszifajták és közeli rokon diploid Prunus fajok fogékonysága a M. laxa okozta termőrészpusztulásra

6.2 A virágszirom fertőzésére adott reakciók összehasonlítása különböző fajtáknál

6.3 A megporzás és virágfertőzés közti összefüggés vizsgálatának eredményei

6.4 Mesterséges termőrészfertőzés eredményei

6.5 Az 'Orange red' és 'Zard' fajta mesterséges levélfertőzésének eredményei

6.6 Az NBS-típus RGA-k és a monilia-ellenállóság kapcsoltsága

6.8 A moniliára fogékony 'Orange red' és az ellenálló 'Zard' fajták között fertőzés hatására kialakuló génexpressziós eltérések

8 ÖSSZEFOGLALÁS 


\section{Rövidítések jegyzéke}

\begin{tabular}{|c|c|}
\hline ATP & adenozin-trifoszfát \\
\hline $\mathrm{bp}$ & bázispár \\
\hline $\mathrm{CC}$ & 'csavart csavar' (coil coiled) két $\alpha$ hélix egymás köré csavarodva \\
\hline cDNS & komplementer DNS \\
\hline cDNS-AFLP & $\begin{array}{l}\text { cDNS amplifikált fragmentumhossz polimorfizmus } \\
\text { (cDNA-Amplified Fragment Length Polymorphism) }\end{array}$ \\
\hline ds & duplaszálú (Double Stranded) \\
\hline DEG & eltérően kifejeződő gén (differently expressed genes) \\
\hline eLRR & extracelluláris leucinban gazdag régiót tartalmazó fehérje \\
\hline GTP & guanozin-trifoszfát \\
\hline HR & túlérzékenységi válasz (hypersensitiv response) \\
\hline $\mathrm{kb}$ & kilobázis (1000bp) \\
\hline MAS & markerekre alapozott szelekció \\
\hline MQ & Milli-Q ioncserélő gyantán megszürt desztillált víz \\
\hline NBS-LRR & nukleotid kötő hely - leucinban gazdag régió \\
\hline PCR & polimeráz láncreakció \\
\hline PDA & burgonya dextróz agar táptalaj \\
\hline PG & poligalakturonáz enzim \\
\hline PGIP & poligalkturonáz gátló fehérje \\
\hline PPV & Plum pox potyvirus \\
\hline PR proteinek & patogénválasz-fehérjék \\
\hline QTL & mennyiségi tulajdonságot meghatározó lókusz \\
\hline RGA & rezisztenciagén-analóg \\
\hline RGH & rezisztenciagén-homológ \\
\hline $\mathrm{R}$ gén & rezisztenciagén \\
\hline $\mathrm{R}$ protein & rezisztenciafehérje \\
\hline RT & reverz transzkripció \\
\hline $\mathrm{s}$ & másodperc (secundum) \\
\hline TDF & transzkriptumból származó fragmentum \\
\hline TIR & Toll/Interleukin-1 Receptor \\
\hline
\end{tabular}




\section{Bevezetés}

Csonthéjas gyümölcsfajokon általánosan károsító faj a Monilinia laxa (Aderh. \& Ruhland) Honey kórokozó. A virág- és hajtásfertőzés elsősorban a meggyen és a kajszin tapasztalható, mint állandó növény-egészségügyi probléma. A kórokozó termőrészpusztulást okoz a virágzáskor csapadékos időjárás esetén. Kerti körülmények esetében általában nem sikeres a védekezés, de még az üzemi termesztésben is kétséges a permetezés eredményessége.

A kajszifajták fogékonysága eltérő mértékű a $M$. laxa termőrész fertőzésre, de teljesen ellenálló fajta a hazai fajták között nem ismert. A termesztésben alkalmazott fajták fogékonyságának mértékéről nem állnak rendelkezésre az összehasonlítást lehetővé tevő pontos adatok. A magyarkajszi-fajták tájszelekciója során természetes körülmények között történt a betegségekkel szembeni ellenállóságra történő szelekció, míg az azt követő kombinációs nemesítésnél a szelekció nem terjedt ki erre a tulajdonságra. A jelenleg terjedő divatos, új külföldi fajták virágzáskori monília ellenállóságról a fajtaleírások nem számolnak be, ezek további kihívásokat tartogathatnak a termesztők számára.

Magyar Gyula már az 1930-as években indított szelekció során, ami az első magyarországi kajszi nemesítési programnak is tekinthető, a téli fagytürés és a $M$. laxa ellenállóság növelését tartotta elsődleges célnak (Pedryc, 2003).

Napjainkban a növénytermesztés sarkalatos pontjává vált a megbízhatóan egészséges és vegyszermentes termékek előállítása. Az engedélyezett növényvédőszerhatóanyagok mennyisége évről-évre csökken, az alkalmazható szerek ára ezzel szemben folyamatosan nő. Ebben a helyzetben az integrált- és bio-növényvédelmi technológiák kidolgozása mellett, a rezisztens fajták előállítása lehet az egyik megoldás a környezettudatos termesztésre, valamint egészséges és gazdaságos kertészeti termékek előállítására. Zöldségfajok esetében, mind az intenzív, mind a szabadföldi termesztésben, a rezisztens fajták használata a termesztéstechnológia meghatározó elemévé vált. A nemesítők a termesztői körökben bevált fajtákat folyamatosan „egészítik ki” különböző kártevőkkel illetve kórokozókkal szembeni rezisztenciával, és dobják piacra az akár 7-8 különböző biotikus tényezővel szembeni ellenállóságot hordozó új fajtákat. A vad fajokból származó rezisztenciagének, már akár 5-6 visszakeresztezéssel átvihetők az új rezisztens fajtába. Az $F_{1}$ hibridek alkalmazása biztosítja a nemesítők munkájának megtérülését, így 
ez a tevékenység jövedelmező üzletágként müködik az egész világon. A nagy jelentőségü zöldségfajok esetében alig találni olyan betegséget, amellyel szemben ellenállóságot ne építették volna be a termesztett fajtákba.

Gyümölcsfajok esetében a fajtakínálat az ellenállóság tekintetében csekélyebb, a nemesítés nem tudja tartani a versenyt a kórokozókkal, kártevőkkel, így egyes fajok csak folyamatos növényvédelmi kezelésekkel termeszthetők biztonságosan. A fásszárú kertészeti növények közül a szőlő és alma fajtaszortimentjében találhatunk olyan több rezisztenciát hordozó fajtákat, amelyek a termesztésben is kisebb nagyobb jelentőséggel bírnak. A keresztezés és visszakeresztezések folyamata, a rezisztenciagének hatásának tesztelése, öröklődésük meghatározása, az új fajta engedélyeztetése legalább 15-20 éves folyamat, így e fajok nemesítése hosszú távú feladat.

A nemesítés felgyorsítását a korai szelekciós módszerek szolgálhatják. A korai szelekció egyes zöldségfajok (paprika, paradicsom) rezisztencia tesztelésekor a vetéstől számított ötödik hétre meghatározható, míg a hosszú generációs idővel jellemezhető gyümölcsfajok esetében ez legtöbbször lehetetlen. A genetikai térképezésen alapuló, az ellenálló fenotípushoz kapcsolt DNS-alapú markerek létrehozása megoldást jelenthet a szelekció felgyorsítására, de a fás szárú növények esetében ez évtizedekig tartó folyamat. Ennek oka a gyümölcs fajok hosszú generációs idejéből és az ültetvényben történő fenotipizálás bizonytalanságából adódik.

A különböző növényfajok és azok kórokozóival történő kapcsolatának fertőzésmenet, növényfajon belüli érzékenység a fertőzésre - pontos meghatározása alapul szolgálhat a nemesítés számára alkalmazható tesztelési módszerek kidolgozásához. 


\section{Célkitűzés}

Munkánk során az alábbi célokat tüztük ki:

1. A tanszéki gyüjteményben lévő kajszifajták és hibridek fogékonyságának bonítálása, valamint érzékenységi sor felállítása a természetes moniliás vesszőfertőzés alapján.

2. A termőrészek fertőzésmenetének pontos leírása, a megporzás és a bibefertőzés közötti kapcsolat feltárása.

3. Az ellenállóság hátterének feltárása, a fertőzésre kialkuló válaszreakció leírása.

4. A monilia ellenálló hibridek azonosítására alkalmas rutineljárás kidolgozása

5. A monilia ellenállósághoz kapcsolt rezisztenciagén analógok azonosítása homológia alapján.

6. A monilia ellenálló és fogékony kajszifajták fertőzését követő génexpressziós eltérések meghatározása a háncsszövetben. 


\section{Irodalmi áttekintés}

\subsection{A csonthéjasok virágzáskori moniliás betegsége: a fertőzéstől a termőrész pusztulásig}

A meggy és kajszi virág- és vesszőpusztulása elsősorban a Monilinia laxa kórokozó fertőzésének következménye. A kórokozó Európában, Ázsiában, Afrikában honos. A virágzáskor uralkodó csapadékos, párás időjárás esetén a kajszi ültetvények növényvédelmét a betegség megelőzésére irányuló kezelések határozzák meg. Az időjárásnak megfelelően a kémiai védekezések száma egy és három kezelés között változhat, ami felszívódó gombaölőszerek alkalmazásával javasolt. (Holb, 2003). A kijutatott növényvédőszer költsége egy rezes lemosópermetezéssel és három felszívódó fungicides kezeléssel 2012. évi árakon számítva hetvenezer forint körül alakult hektáronként, amihez még húszezer forint kijutatási munkadíj társul.

Az ellenállóság vizsgálatához a kórokozó fejlődés- és fertőzésmenetének ismerete alapvető fontosságú. A kórokozó a fertőzött növényi szöveteken gyors barnulást, szöveti macerációt okoz, ami a szövetek pusztulásával jár (Byrde és Willetts, 1977). A betegséget ezen tipikus tünetek alapján a szerzők csonthéjas fajok barna rothadásaként (brown rot of stone fruits) nevezték el. A Monilinia nemzetség fajai nekrotróf gombakórokozók közé sorolhatók, amelyek jellemzője, hogy a gazdaszervezetbe hatolva enzimjeikkel a sejtek dezintegrációját okozzák, fitotoxinjaik közvetlen sejtelhalást váltanak ki (Honey, 1936). A nekrotrófok hifái a már elhalt sejtek közé, illetve a sejtekbe hatolnak be, bontják és felveszik azok anyagait. Bár a nekrotróf kórokozók és a szaprotrófok tápanyagaikat egyaránt az elhalt sejtekből nyerik, fontos eltérés közöttük az, hogy a sejtek elhalását csak a nekrotrófok képesek kiváltani (Jakucs és Vajna, 2003). Wood (1960). A fertőzés során a gyors szövetbarnulást a fenolos vegyületek oxidációjával magyarázták, ami a kórokozó és a növényi polifenoloxidázok müködésének eredménye. Az elpusztított szövetek a vízvesztés következtében összeszáradnak, a gyümölcsfertőzés esetében a fán fennmaradva gyümölcsmúmiákat hoznak létre. A gyümölcsmúmiák és a fertőzött vesszők biztosítják a kórokozó túlélő képleteinek fennmaradását. A kórokozó életciklusait a 1. ábra szemlélteti.

A kórokozó fertőzési folyamatát Glits (2000) foglalta össze. Az M. laxa által kiváltott tünetek a virágon, a hajtáson, a vesszőn, az ágon és a gyümölcsön figyelhetőek meg. A kórokozó fertőzésekor a virág csésze- és sziromlevelei világosbarnára színeződnek, a virágkocsány elhal, és megfigyelhetőek rajta a szürke színü, apró exogén sztrómák. A 
termőnyársak elpusztulnak és a tövüknél mézgacseppek jelennek meg. A hajtás alsó harmadában szabálytalan alakú, több ízközre kiterjedő barna folt jelentkezik, amely később kifakul, felületét pedig exogén sztrómákból álló bevonat borítja. Ezek után a hajtás először meglankad, majd leszárad. Akkor is bekövetkezhet hajtáspusztulás, ha az a rothadó gyümölcs mellett található. A vesszőn és a termőnyársak tövében ovális, sötétbarna, kissé besüppedő foltokat láthatunk. Ezekből az ágakon rákos sebek alakulnak ki, amelyekben elszórtan szürke exogén sztrómák figyelhetőek meg. A gyümölcsök esetében egyre nagyobbodó barna színủ rothadás látható, amely végül az egész gyümölcsre kiterjed. Ezeken a rothadó foltokon elszórtan apró, szürke, exogén sztrómákból álló bevonat alakul ki (Glits, 2000).

A $M$. laxa jelentős fertőzési forrásai a gyümölcsmúmiák. A gyümölcsmúmiákon található exogén sztrómákon az előző évben képződött konídiumok télállóak, sőt a tél folyamán újabb konídiumok is keletkeznek. A M. laxa esetében 5-10 C hőmérsékleten maximális a konídiumok sporulációja, míg 25 C-on a sporuláció századára csökken a PDA táptalajon nevelt tenyészetek esetében (Harada és mts. 2004.). A Monilinia nemzetséget leíró Honey (1936) szerint az M. laxa faj esetében az ivaros (anamorph) apotéciumok és azokon képződő aszkospórák nagyon ritkán figyelhetők meg, ezzel szemben az északamerikai elterjedésű $M$. fructicola tavaszi csonthéjas gyümölcsfajok virágfertőzésénél mind az ivaros, mind az ivartalan alak fertőzése jellemző. Tavasszal a gyümölcsmúmiákon új exogén sztrómák fejlődnek, amelyek láncokban konídiumokat füznek le. Tavasszal a különböző fertőzési forrásokon létrejött konídiumok légmozgással vagy esőcseppel a virágra jutnak. A virágra került konídiumok a bibén ugyanúgy csíráznak, mint a pollen. A konídiumok csíratömlője a bibecsatornán keresztül a hajtásokba kerül (Glits, 2000).

Ezzel szemben Byrde és Willetts (1977) szerint az összes virágrész szolgálhat infekciós pontként. A fertőzés kezdődhet a szirmon, a porzón és bibén is. A kórokozó 48 óra alatt képes a fertőzött virágrészek teljes kolonizációjára, és a csészén majd virágkocsányon keresztül a termörészek háncsszövetébe jut (Weaver, 1950).

A gyümölcsbe a kórokozó a kártevő állatok által ejtett, valamint a jég ütötte sebeken, illetve az egyenetlen vízellátás miatt keletkezett repedéseken keresztül jut. Az egymással szorosan érintkező, terméscsoportban álló gyümölcsökbe ezután már az ép héjon keresztül fertőzhet tovább a kórokozó (Glits, 2000). 
A betegség elnevezése a károsított növényfaj és az okozott tünet alapján alakult ki. A magyar elnevezés esetén a dolgozatban Kövics (2000) által készített rendszertani alapon álló, fitopatogén gombanév összeállítását vettem alapul, miszerint a betegség neve: a kajszi moniliás betegsége. A betegséget kiváltó kórokozó esetében a tudományos név használatakor a dolgozatban a melbourni XVIII. International Botanical Congress Nomenclature Section állásfoglalása (McNeill és Turland, 2011) - egy gomba egy név alapján faj ivaros alakjának a nemzetközi irodalomban is használt nevét -Monilinia laxahasználtam, habár a fajt leíró müvében Honey (1936) az apotéciumos (teleomorf) alak pontos leírását nem közli és az általam feldolgozott irodalmakban sem találtam erről leírást.

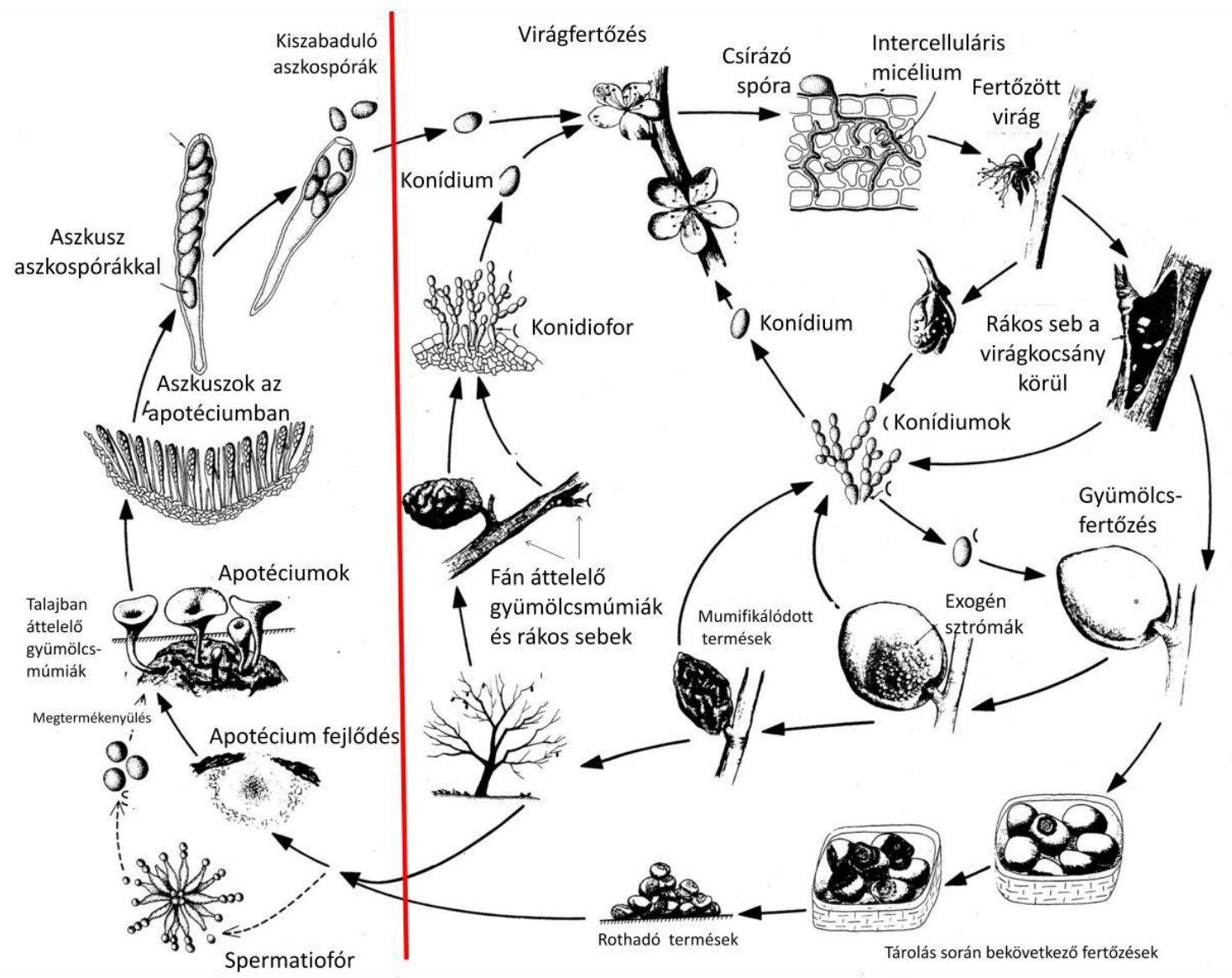

1. ábra Csonthéjas gyümölcsfajok moniliás fertőzésmenete. Az európai elterjedésü

Monilinia laxa fertőzésmenetében nincs jelentősége az ivaros fejlődési alaknak, ami a kép bal oldalán látható (Agrios, 1997).

\subsubsection{A bibe konídiumos fertőzése és a ribonukleázok gomba fejlődését gátló hatása}

A pollentömlő fejlődése a gombakonídiumok csírázásával több szempontból is nagy hasonlóságot mutat. A gyors, polarizált sejtnövekedés és a tömlőszerü fejlődés 
feltünően hasonló. A virágos növények megtermékenyülése és a gombák fertőzése között azonos receptorfehérjék közremüködését bizonyították Kessler és mts. (2010). A XIX. században a kutatók a pollentömlőt növényi gombakórokozónak gondolták, aminek továbbfejlesztése szerint a virágfertőző gombák a pollennel azonos mód fertőzik a meg a virág termőjét (Govers és Angenent, 2010).

A meggy és kajszi moniliás virágfertőzés jelentőségéről már 1930-ban Kerekes beszámol a Növényvédelem folyóiratban. A virágfertőzés elképzelése szerint a bibén keresztül történik a pollentömlö fejödéséhez hasonló mód (2. ábra).

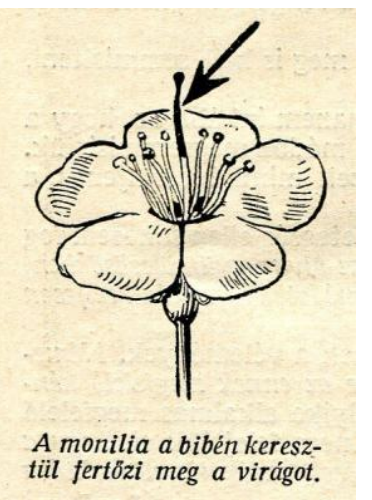

2. ábra A meggy moniliás bibefertőzése. A kórokozó bibecsatornán keresztül a pollennel azonos módon fertőzi meg a virágot (Kerekes, 1930).

Ngugi és Sherm (2004) az észak-amerikai kék áfonya (Vaccinium corymbosum L.) Monilinia vaccinii-corymbosi okozta virágfertőzésekor a konídium bibén történő csírázását és az ovárium fertőzését vizsgálták. A konídium és a pollen hasonlómód szelektíven tapad meg a bibére jellemző felületen más felületekhez képest, ami bizonyítja a pollen és a konídium közötti mimikri jelenségét. A kék áfonyát természetes körülmények között károsító $M$. vaccinii-corymbosi összehasonlítva az észak-amerikai elterjedésü Monilinia fructicola csonthéjas fajok kórokozójával, leírták, hogy a M. vaccinii-corymbosi elágazás nélküli, egyszálas hifákat fejlesztett a bibeszövetben a pollen fejlődésével hasonló mód, míg a $M$. fructicola sürün elágazó az egész bibeszövetet kolonizáló hifákat fejlesztett.

A tápanyagokban gazdag bibe és a transzmissziós szövete kórokozó gombák és baktériumok célpontja. A bibe patogén gombák és baktériumok fertőzése elkerülésében RN-áz enzimeinek szerepét feltételezte Schrauwen és Linskens (1972). A virágokban szekretálódó nektár nagy mennyiségben tartalmaz cukrokat lipideket, fehérjéket. A dohány esetében antiszeptikus hatását a megporzásért felelős szervezetek csalogatásáért felelős nektárnak a magas hidrogénperoxid koncentrációjával magyarázta Carter és Thornburg 
(2004). Hilwig és mts. (2010) petúnia nektárban a növényvilágban elsőként mutattak ki $S$ RN-ázzal nagy hasonlóságot mutató két RN-áz fehérjét, az RNase Phy3 és RNase Phy4 -et. Feltételezik, hogy ezek a fehérjék a nektár patogénekkel szembeni védelmében játszanak szerepet.

Hugot és mts. (2002) bizonyították, hogy dohány „S-like RNase” enzim in vitro körülmények között gátolja a Fusarium oxysporum és a Phytopthora parasitica fejlödését (3. ábra).

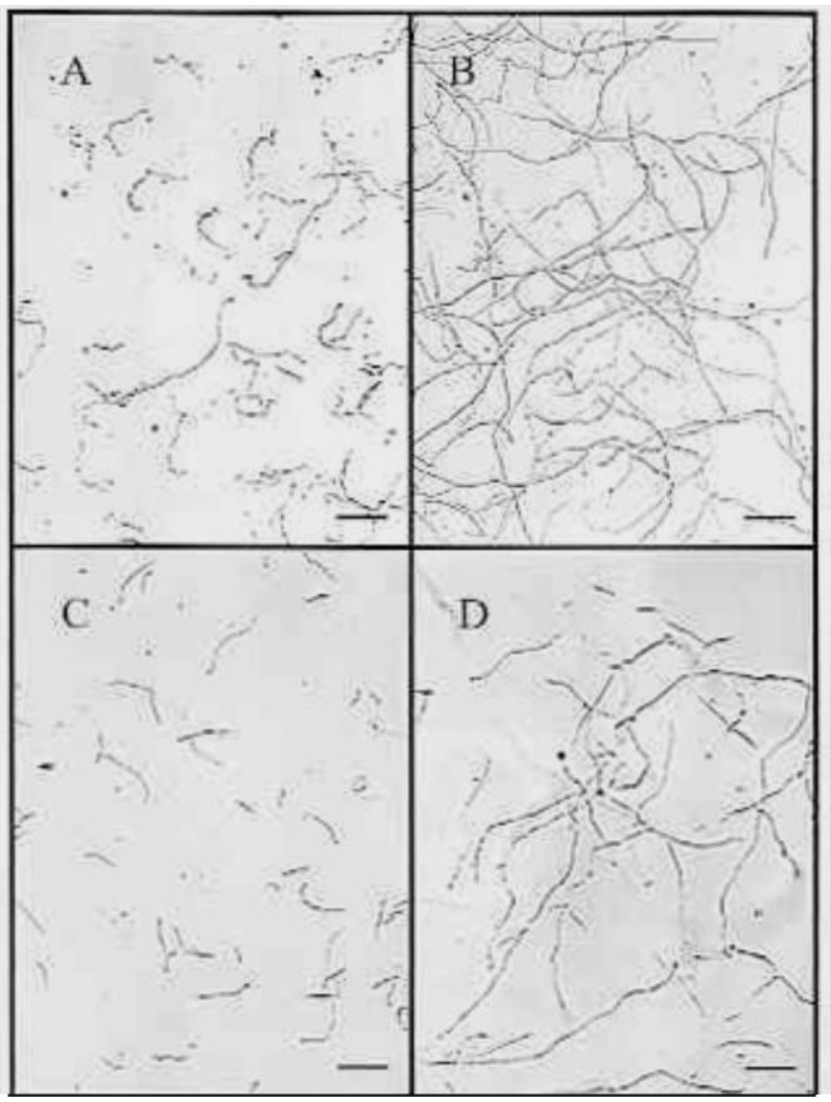

3. ábra $\mathrm{Az} \mathrm{RN}$-áz $\mathrm{NE}$ ( $S$-like RNase) enzim gombamicélium-növekedésének gátlása. A Phytophthora parasitica zoosporák és Fusarium oxysporum konídiumok 48 órás folyékony táptalajban nevelt micéliumai ('B' és 'D' kép) és RN-áz NE enzimet (50 $\mu \mathrm{g} / \mathrm{ml}$ ) tartalmazó táptalajban gátolt növekedésü gombamicéliumok ('A' és 'C' kép). A Phytophthora parasitica $50 \%$-kal, míg a Fusarium oxysporum több mint $90 \%$-kal rövidebb micéliumokat fejlesztett a RN-áz NE enzimet tartalmazó táptalajban (Hugot és mts., 2002).

\subsubsection{A megporzás hatása $M$. laxa bibefertőzésére}

A kajszi esetében a $M$. laxa általi virágfertőzés menetét a megporzással összefüggésben Tzoneva és Tzonev (1999) vizsgálta. Kérdésük az volt, vajon a 
megporozatlan és megporzott bibe azonos módon képes-e a fertőzés nyílt kapujaként szolgálni. Öt eltérő kezelést végeztek négy vegetációs időszakon keresztül kajszivirágokon. A virágzás után 5 héttel felvételezték a természetes körülmények között fertőzött virágok számát. Eredményeiket az 1. táblázat foglalja össze. A kézzel megtermékenyített és kasztrált virágokon keresztül nem volt képes a kórokozó megfertőzni a fákat ('B' és 'D’ kezelés), míg a megporzott, de nem kasztrált ('E' kezelés) kezelés során a virágok $12 \%$-ának fertőzése következett be. Feltételezéseik szerint a fertőzés sikertelenségét a megtermékenyítés hatására a bibében keletkező, a gomba fejlődését gátló vegyület okozza. A kísérleteik során használt fajtákról és ezek termékenyülési viszonyairól nem számoltak be.

1. táblázat. Öt eltérő virágzáskori kezelés hatása a kajszi virágzáskori moniliás fertőzöttségére (Tzoneva és Tzonev,1999).

\begin{tabular}{|c|c|c|c|}
\hline \multirow{2}{*}{ Vizsgálat éve } & Kezelés & Összes virágszám & $\begin{array}{c}\text { Fertözött virágok aránya } \\
(\%)\end{array}$ \\
\hline \multirow{3}{*}{1991} & $\mathrm{~A}$ & 4230 & 86 \\
\cline { 2 - 4 } & $\mathrm{B}$ & 17447 & 0 \\
\cline { 2 - 4 } & $\mathrm{C} 1$ & 4738 & 95 \\
\hline \multirow{2}{*}{1993} & $\mathrm{~A}$ & 2818 & 77 \\
\cline { 2 - 4 } & $\mathrm{B}$ & 9159 & 77 \\
\hline \multirow{3}{*}{1995} & $\mathrm{~A}$ & 2940 & 75 \\
\cline { 2 - 4 } & $\mathrm{C} 2$ & 1468 & 0 \\
\cline { 2 - 4 } & $\mathrm{D}$ & 7210 & 68 \\
\hline & $\mathrm{A}$ & 2333 & 0 \\
\cline { 2 - 4 } & $\mathrm{D}$ & 5871 & 12 \\
\cline { 2 - 4 } & $\mathrm{E}$ & 1200 & $\mathrm{~m}$ \\
\hline
\end{tabular}

A: szabad elvirágzású (kezeletlen pozitív kontroll). B: kasztrált, megporzott, és papírzsákkal izolált, $\mathrm{C} 1$ : nem kasztrált, vászonzsákkal izolált $\mathrm{C} 2$ : nem kasztrált, papírzsákkal izolált, D: kasztrált és megporzott, E: megporzott, nem kasztrált és nem izolált. 


\subsection{Kajszifajták és rokon Prunus fajok fogékonysága a moniliás virág és vesszőfertőzésre}

Hazánkban Benedek és mts. (1990) 6 éven keresztül vizsgálták 8 kajszifajta vesszőfertőzöttségét egy kecskeméti ültetvényben. A fajták termőrész pusztulását az 2. táblázat ismerteti.

2. táblázat. Nyolc magyar kajszifajta moniliás vesszőfertőzöttsége százalékos mértékben Benedek és mts. (1990) után.

\begin{tabular}{|l|c|c|}
\hline \multirow{2}{*}{ Fajta név } & \multicolumn{2}{|l|}{ Vesszőfertőzöttség (\%) } \\
\cline { 2 - 3 } & I. ismétlés & II. ismétlés \\
\hline Borsi-féle kései rózsa & 9 & 11 \\
\hline Kécskei rózsa & 16 & 7 \\
\hline Mandulakajszi & 12 & 14 \\
\hline Gönci magyarkajszi & 11 & 28 \\
\hline Szegedi mamut & 12 & - \\
\hline Ceglédi óriás & 10 & 27 \\
\hline Nagykőrösi óriás & 12 & 12 \\
\hline Ceglédi bíborkajszi & 14 & 9 \\
\hline
\end{tabular}

A legerősebb fertőzés az összes termőrész közel 30 \%-át pusztította el. A termőrész pusztulást két ültetvényrészben vizsgálták és a két terület között jelentős eltérést tapasztaltak azonos évben.

A Nyikitai Botanikus Kert kutatói három éven keresztül vizsgáltak különböző Prunus fajok, ezek kajszival létrehozott hibridjei és kajszi fajták M. laxaval szembeni ellenállóságát. Az általuk felállított öt kategóriás fogékonysági sorban az 1. kategóriába a teljesen ellenálló genotípusokat sorolták be, míg az 5. kategóriában a fogékony genotípusok találhatók. A megfigyeléseik alapján a vizsgált kajszi fajták egyöntetüen a fogékony csoportba kerültek (Komar-Tyomnaya és Richter, 2000). Az eredményeiket a 3. táblázat foglalja össze. 
3. táblázat. Különböző Prunus fajok és ezek hibridjeinek ellenállósága a $M$. laxa kórokozó vessző- pusztulásával szemben (Komar-Tyomnaya és Richter, 2000) A genotípusok csoportosítása 1-től (teljesen ellenálló) 5-ig (fogékony) terjedt.

\begin{tabular}{|c|c|}
\hline 1. & $\begin{array}{l}\text { P. cerasifera } \times P . \text { armeniaca: 'Sintez', 'Uryuko-alyca', } P . \text { domestica } \times 1 . \\
\text { armeniaca: 'Kleimen } \mathrm{x} \text { 'Krasny partizan' }\end{array}$ \\
\hline 2. & $\begin{array}{l}\text { P. mandshurica, P. mume 'Rubra plena', P. mume 'Rosea plena', P. dasycarpa } \\
\text { 'Grossa tardiva', 'Manaresi' 'Tlor Ciran', 'Picole precocte', Plumcot: 'Zamshevy', } \\
\text { 'Krasny', }\end{array}$ \\
\hline 3. & P. dasycarpa: 'Black apricot', 'Jolty Kan', 'Persidsky chorny', 'Sh \\
\hline 4. & P. ansu:'Zolotisto Jolty', P. dasycarpa:'Melitopolski Chorny' \\
\hline 5. & $\begin{array}{l}\text { P. davidiana, P. sibirica, P. armeniaca } \times P . \text { mandshurica } \times P . \text { sibirica: 'Sacer', } \\
\text { 'Tovariscs' }\end{array}$ \\
\hline
\end{tabular}

Tzonev és Yamaguchi (1999) kajszival közeli rokon fajok M. laxa virágfertőzéssel szembeni ellenállóságát vizsgálták Japán Tsukuba tartományában. A vizsgált 123 fajta közül 43 P. armeniaca var. ansu, 20 P. armeniaca és 11 genotípus ezek hibridje volt. A 47 további fajta közül 30 a $P$. mume fajhoz tartozott, 19 genotípus pedig $P$. mume és $P$. armeniaca var. ansu keresztezéséből származó hibrid volt. Két $P$. salicina fajtát is bevontak a vizsgálataikba. A vizsgált $P$. armeniaca var. ansu, és ezek $P$. armeniaca-val képzett hibridjeinek erős fertőzöttsége alapján megállapították, hogy ezek a genotípusok rezisztencia forrásként nem alkalmasak a kajszinemesítés számára. A vizsgált $P$. mume fajták teljes immunitást mutattak a $M$. laxa fertőzésével szemben. A két vizsgált japánszilvafajta a 'Sordum' és 'Red June' az M. laxa fertőzésével szemben teljesen ellenálló volt. P. armeniaca var. ansu Nyugat-Kína párás klímájú területein terjedt el, emiatt feltételezték, hogy a faj több gombás betegséggel - ideértve a $M$. laxa-át is szemben ellenállósággal rendelkezik (Mehlenbacher és mts., 1990). Harada és mts. (2004) Japánban a Prunus mume fajon súlyos vesszőpusztulást okozó új monilia fajt azonosítottak, a Monilia mumecola-t.

Balan és mts. (1999) 124 fajta és hibrid ellenállóságát vizsgálták Romániában. A mesterséges virágfertőzés során az ágakat $M$. laxa szuszpenzióval permetezték le, majd a párás körülmények biztosítása érdekében, 48 órára vizes papírral burkolták le az ágakat. A vizsgált fajták érzékenységi sorát a fertőzés gyakorisága és erősségének szorzatából számították (attack level, A.L.). A fertőzés után 60 nappal értékelték a kísérletet. A vizsgált 
fajták és egy hibrid ellenállósága az alábbiak szerint alakult: teljesen ellenálló (tünetmentes) a K55-39 hibrid, ellenálló (AL: 0,5-12) a 'Precoce de Italia', közepesen ellenálló (AL: 12,5-20) 'Precoce de Bergeron', 'Boccucia, 'Tivoli', mérsékelten fogékony (AL: 20,5-30) 'Excelsior', 'Canette', 'Manitoba', fogékony (AL: 30,5-50) a 'Beregron', 'NJA 19', 'Neptun 40', 'Royal', 'Sungiant', míg nagyon fogékony (AL> 50) a 'Francousi', 'Precoce de Colomer', 'NJA42', 'Paksi magyarkajszi', 'Erevani', 'Litoral', 'Saturn', 'Cafona' és 'Framingdale'.

Crossa-Raynaud (1969) kajszi és mandula fajták $M$. laxa érzékenységét vizsgálta mesterséges fertőzés alapján. A fertőzés levágott 2-4 éves fás részeken történt téli és kihajtás utáni időpontban. A kísérlet beállítását megelőzően a szabadföldi megfigyelésekből szerzett tapasztalataik alapján fogékony kontrollként a 'Canino' fajtát, míg ellenállóként a 'Hamidi' fajtát választották. Az ágakon 3 héttel a fertőzést követően felvételezték az elhalt szövet hosszát. Az eredményeket a 4. táblázat mutatja be.

4. táblázat. Mediterrán kajszifajták fogékonysága a $M$. laxa kórokozó mesterséges ágfertőzésére Crossa-Raynaud (1969) kísérletei alapján.

\begin{tabular}{|l|c|c|c|c|}
\hline \multirow{2}{*}{$\begin{array}{c}\text { Érzékenységi sorrend a M. laxa } \\
\text { mesterséges ágfertózésére }\end{array}$} & \multicolumn{4}{|c|}{ Fertőzés hossza és szórása (cm) } \\
\cline { 2 - 5 } & \multicolumn{3}{|c|}{ Télen } & \multicolumn{2}{c|}{ Tavasszal } \\
\hline Canino (fogékony) & 11,3 & 1,25 & 11,6 & 0,43 \\
\hline Búlida & 7,2 & 1,32 & 8,8 & 0,32 \\
\hline R. du Roussilon & 8,1 & 0,75 & 8,6 & 0,15 \\
\hline Amor leuch & 5,4 & 0,79 & 7,1 & 0,33 \\
\hline Moorpark & 4,8 & 0,51 & 6,0 & 0,17 \\
\hline Fakoussi & 4,7 & 0,37 & 5,5 & 0,3 \\
\hline Real d'Imola & 4,3 & 0,61 & 5,3 & 0,26 \\
\hline Hatif colomer & 4,1 & 0,53 & 5,1 & 0,37 \\
\hline Jaubert-Foulon & 3,8 & 0,47 & 5 & 0,24 \\
\hline Derby Royal & 3,5 & 0,5 & 4,3 & 0,18 \\
\hline Hamidi (ellenálló) & 2,5 & 0,56 & 3,4 & 0,16 \\
\hline
\end{tabular}




\subsection{A kajszi M. laxa ellenállóság növelésére irányuló nemesítési tevékenység}

A kórokozókkal és kártevőkkel szembeni ellenállóság, a gyümölcsnemesítés során a második legfontosabb szemponttá vált a gyümölcs tulajdonságok után, mert a legtöbb gyümölcsfaj termesztése mára csak kémiai védekezéssel történhet gazdaságosan (Gardiner és mts., 2007). Az ellenálló fajták alkalmazása az egész társadalom és a termesztők által érezhető előnyökkel jár. A növényvédőszerek mellőzésével csökken a környezetszennyezés és a termesztés költségei is (Reisch és Pratt, 1996).

A monilia-ellenálló kajszi hibridek előállításáról keresztezéses nemesítéssel elsöként Crossa-Raynaud (1969) számol be. A 'Hamidi' × 'Canino' 45 egyedes utódpopulációjának mesterséges fertőzése alapján megállapította, hogy az utódokban megjelenik az ellenálló ‘Hamidi’ fajta ellenállósága. A mesterséges ágfertőzések során, az utódokon mért fertőzés terjedésének hossza folyamatos eloszlást mutatott a két szülö fajtához képest. Ez alapján a szerző a rezisztenciát poligénikus meghatározottságúnak feltételezte.

Nicotra és mts. (2006) hét éves kajszi monilia rezisztencia nemesítési program eredményeiről számol be. Munkájuk során 17 keresztezési kombinációból származó 1200 utódot értékeltek. Az ellenállóság forrásaként az 'Ivone Liverani', 'Amebile Vecchioni', 'Stark Early Orange', 'Perfection' és a 'Hamidi' fajtákat alkalmazták. A fertőzéseket Crossa-Raynaud (1969) által kidolgozott protokoll szerint végeztek el. A fajták vizsgálatakor megállapítják, hogy a termőrész pusztulás mértéke a virágzási idővel is összefügg. Véleményük szerint, a korai virágzású fajták esetében nagyobb fertőzéssel kell számolni. Az ellenállóság öröklödéséről megállapítják, hogy poligénikus jellegü, de az utódok között domináltak az ellenálló egyedek.

A török 'Hacihaliloglu' fajta ellenállóságának növelése érdekében Gulcan és mts. (1999) keresztezéseket végeztek az ellenállónak tartott 'Boccucia', 'Ivonne Liverani', 'Nugget', és 'San Casterese' fajtákkal. A tavaszi mesterséges vesszőfertőzés során az összes genotípus esetében a vesszők teljes hervadását és száradását tapasztalták, így a végső, 3-4 hét után kialakuló tünetek alapján értékelték az ellenállóságot.

Csonthéjas fajok közül a meggy monilia rezisztens fajták nemesítése már 1990-es évek elején megkezdődött a Gyümölcs- és Dísznövény Kutató Fejlesztő Kht.-ban. Az ültetvényben kilenc meggyfajta mesterséges virágfertőzésekor a 40-91 \% között változott a 
fertőzött virágok száma. Mindezek mellett az ellenállónak meghatározott 'Csengődi' és 'Bosnyák' fajtákon ágelhalást nem okozott a fertőzés (Rozsnyay, 2001). A meggy Monilinia ellenállóságának növeléséröl nemesítéssel legújabban hazánkban Szügyi és mts. (2012) számoltak be. A természetes, ültetvényben tapasztalható fertőzés és a mesterséges ágfertőzés értékelése az ellenállónak tartott 'Csengődi' és a fogékonynak ismert 'Érdi bőtermő' és a két fajta tíz hibridjén történt. A tíz hibrid a spontán fertőzés alapján került kiemelésre a 120 egyedes hibridcsaládból. Az egyedek ellenállóságának összehasonlítása a két fertőzési módszerrel (természetes fertőzés és mesterséges vesszőfertőzés) teljes ellentmondást mutatott, a mesterséges vesszőfertőzés során nem tapasztaltak jelentősebb eltérést a genotípusok között egyöntetüen pusztult mindegyik háncsszövete. A két eltérő fenotípusú szülő fajta mesterséges vesszőfertőzése során is jelentéktelen eltérést tapasztaltak. A tíz kiemelt hibridből a természetes fertőzés alapján öt ellenálló képessége a ‘Csengődi’ fajtával azonos mértékü volt az ültetvényben történt bonitálás alapján.

\subsection{A növényi rezisztenciagének}

\subsubsection{A növényi rezisztenciagének csoportosítása}

A növényi kártevők és kórokozók eltérő stratégiákat alkalmaznak a növényi szövetek energiaforrásként történő felhasználása céljából. A fitopatogén baktériumok a sejtek intercelluláris járataiba a sztómákon, néha mechanikai sérüléseken át jutnak be, ahol felszaporodnak és a sejteket elpusztítják. A fonálférgek és levéltetvek a szúró-szívó szájszervükkel szerzik meg a táplálékukat a növényi sejtekből. A gombakórokozók a legváltozatosabb úton képesek a növényi gazdaszervezet fertőzésére. Egyes kórokozó gombák a gazdaszervezetre történő érkezésük után annak légzőnyílásain jutnak az intercelluláris járatok közé, a szimbionta gombaszervezetekhez hasonlóan hausztóriumokat fejlesztenek, amik a citoplazmából történő tápanyagfelvételt biztosítják számukra. Ezzel szemben más gombakórokozók az epidermiszt átszakítva jutnak a gazdaszervezetbe, enzimeikkel és toxinjaikkal pusztítják el a sejteket, és kolonizálják a fertőzött szöveteket. Az eltérő patogének mindegyike a fertőzés sikerességének érdekében virulencia faktorokat alkalmaz (Jones és Dangl, 2006).

A növények a kórokozóikkal és kártevőikkel szembeni védekezéshez különböző, virulencia faktorokat felismerő rendszereket, és erre specifikus reakciókat alakítottak ki. A specifikus felismerés a növényi rezisztencia $(R)$ gén termékének és a kórokozó közvetlen vagy közvetett virulencia faktorainak találkozásakor alakul ki. Az ezt követő jelátviteli 
események rezisztencia esetén különböző védekezési válaszokon keresztül a hiperszenzitív reakció (HR) kialakulását okozzák (Dangl és Jones, 2001). Ezt a rendszert több mint hatvan éve ismerte fel Flor (1955) és megalkotta a 'Gene for Gene' elméletet.

Növényekből, elsősorban modell fajokból, 2006-ig több mint 70 specifikus rezisztenciagént izoláltak és bizonyították funkciójukat (Xiao, 2006). Ezek a rezisztenciagének, habár teljesen eltérő típusú patogénekkel (vírusok, bio- és nekrotróf gombák, nematódák, baktériumok) szemben biztosítanak ellenállóságot, öt osztályba sorolhatók az általuk kódolt fehérjék szerkezeti felépítése és azok feltételezett müködési mechanizmusa alapján. Még az egy osztályba sorolt gének is sokszor változatos kórokozó csoportok felismeréséért felelősek (4. ábra).

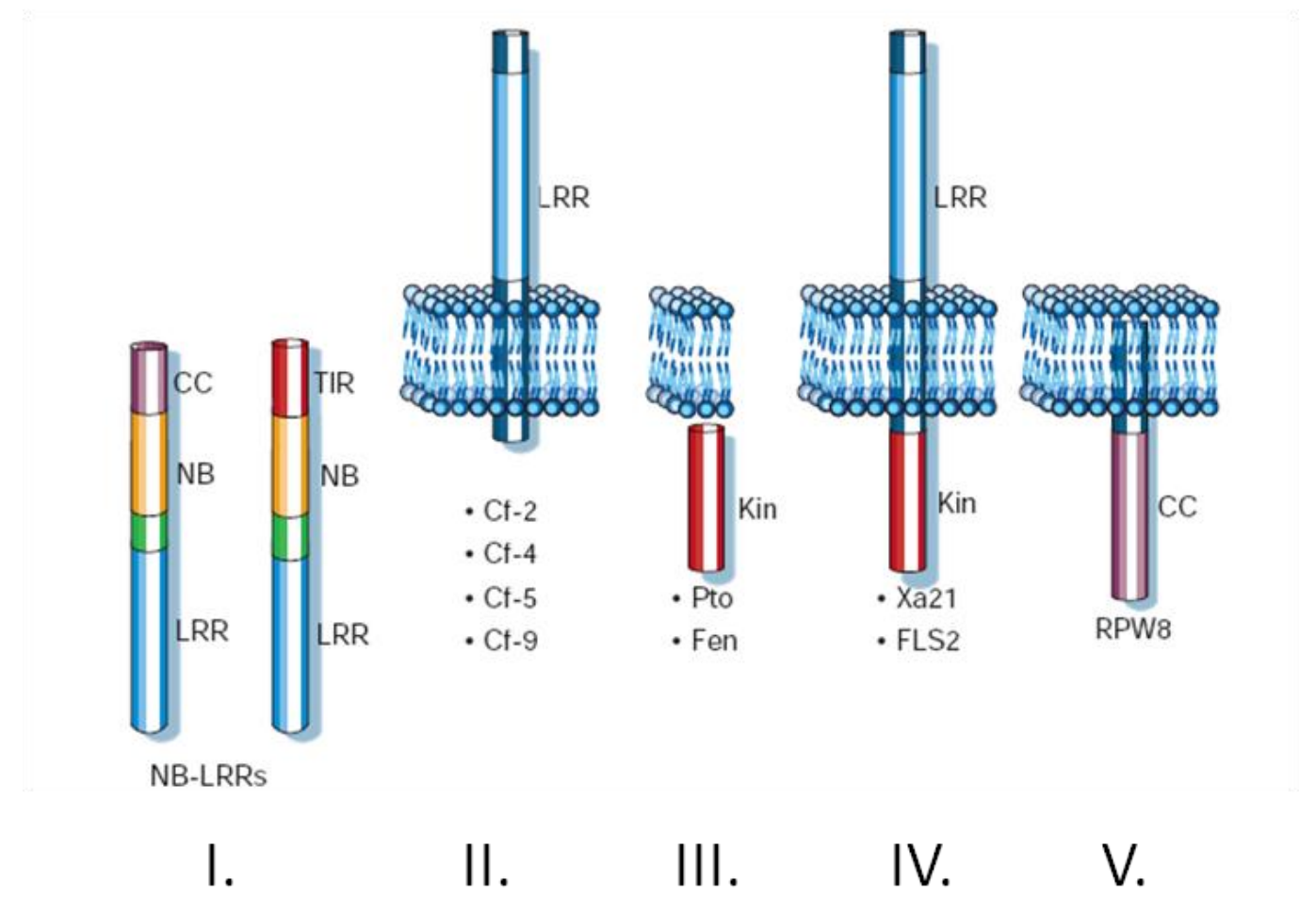

4. ábra $\mathrm{Az}$ öt specifikus ellenállóságot biztosító növényi rezisztencia fehérjecsoport: $\mathrm{Az}$ első, az NBS-LRR csoport a legnagyobb R proteincsoport, amely a citoplazmában, ritkán membránhoz kapcsoltan helyezkedik el. Az $\mathrm{N}$ terminális részén különböző (CC vagy TIR) doménokat tartalmazhat. A második csoportba tartozó $C f-x$ proteinek egy transzmembrán és egy LRR doménnal rendelkeznek. A harmadikként ábrázolt csoportba tartozik például a Pto gén, mely egy citoplazmatikus Ser/Thr kináz domént kódol. A negyedik csoportban lévő fehérjék egy transzmembrán, egy kináz és egy extracelluláris LRR domént hordoznak. Ilyen gének például az Xa21 és $F L S 2$. Az ötödik csoporthoz tartozik a $R P W 8$ gén, ez egy transzmembrán fehérje, ami az $\mathrm{N}$ terminálisán egy feltételezett jelfelismerő $\mathrm{CC}$ domént kódol (Jones és Dangl, 2006) 
Az első - legnagyobb számban képviselt - csoportra jellemzö, hogy egy NBS-LRR (nucleotide binding site - leucine-rich repeats) régiót tartalmazó fehérjét kódol. Az NBS régió, azaz nukleotid-kötőhely fontos szerepet játszik az ATP és GTP megkötésében. Az LRR, vagyis leucinban gazdag régió a rezisztenciagének specifitását biztosítja. Ezek a gének tovább csoportosíthatók annak alapján, hogy analógjaik az $\mathrm{N}$ terminálison hordoznak egy TIR (Toll/Interleukin-1 Receptor) vagy egy CC (coiled-coil) típusú domént. Az első alosztály TIR doménje hasonlóságot mutat a Drosophila Toll és az emlősök Interleukin transzmembrán receptorainak doménjeivel. A második alosztály egy coiledcoil, vagyis feltekeredett spirál doménnel rendelkezik (Dangl és Jones, 2001).

Az egyszikü növények csak CC-NBS-LRR típusú működő géneket tartalmaznak, kétszikü növényekben pedig mindkét csoport jelen van (Xiao, 2006). A genetikai vizsgálatok alapján megállapították, hogy ezek az RGA-k a genomban elszórtan, de csoportokba, ún. klaszterekbe rendeződve találhatók (Kanazin és mts., 1996). Ez a géncsoport alapvetően obligát biotrófok, hemibiotrófok ellen biztosít védelmet (Jones és Dangl, 2006), habár a paradicsomból izolált I 2 (Simons és mts., 1998) és a sárgadinnyéből leírt Fom-2 (Joobeur és mts., 2004) nekrotróf fuzáriumfajokkal szembeni rezisztenciagének a CC-NBS-LRR csoportba tartoznak.

A második csoportba olyan gének sorolhatók, amelyek membránon áthatoló, nagyméretű extracelluláris LRR régiókkal rendelkező fehérjéket kódolnak.

A harmadik csoport azon gének csoportja, amelyek egy citoplazmatikus Ser/Thr kináz domént tartalmazó fehérjét kódolnak.

A negyedik csoportba az intracelluláris proteinkináz és transzmembrán receptorral ellátott, extracelluláris LRR doménnel rendelkező rezisztenciagének tartoznak.

Az ötödik, utolsó csoportot olyan gének alkotják, amelyek által kódolt membránfehérjén egy coiled-coil domén található (Dangl és Jones, 2001).

\subsubsection{Növényi rezisztenciagén-analógok azonosítása}

Azokat a szekvenciákat, amelyek tartalmazzák az NBS domént, rezisztenciagénanalógoknak (RGA) nevezik (Kanazin és mts., 1996). Ezzel szemben Qiang és mts. (2007) 228 Rosaceae szekvencia elemzése alapján rezisztenciagén-homológnak nevezi ezeket a szekvenciákat. A homológia két szekvencia közös evolúciós eredetét jelenti. Ennek alapján két gén lehet ortológ, ha két különböző fajban találhatók és egy közös ös génből 
származnak, amely a fajok közös ősében volt jelen. Két gén paralóg, ha egy organizmusban található, egy közös ős génből génduplikáció útján jöttek létre, és az azt követő divergens evolúció során alakultak ki. Általában különböző, de összefüggésben lévő funkciókat látnak el. Ezzel szemben az analógia közös evolúciós eredet nélküli hasonlóság (Patthy, 2007). A közös evolúciós eredet bizonyítása nélkül ezért a rezisztenciagén-analóg kifejezést szerencsésebb alkalmazni.

Növényi RGA-k izolálása alapjául a különböző rezisztenciagén-csoportok szekvenciaelemzése által meghatározott konzervált régiók ismerete szolgál. Ezen konzervált régiókra tervezett degenerált primerek alkalmazásával minden előzetes genomszekvencia-ismeret nélkül lehetséges rezisztenciagének analóg (RGA) szekvenciáinak felszaporítása és meghatározása (Xiao, 2006). Az így kapott szekvenciákból következtetett aminosav-sorrendek szekvencia adatbázisok szekvenciáival történő illesztése alapján feltételezhetjük a homológiát.

A legnagyobb számban klónozott rezisztenciagén-analógok az NBS domén DNSszekvenciájának meghatározásából származnak. A fehérje NBS doménje a jelátviteli út során ATP és GTP molekulák megkötésére szolgál (Dangl és Jones, 2001). Az NBS domén változékonyságát növelő mutációk nagy gyakorisága miatt Qiang és mts. (2007) más funkciót feltételez. Az NBS domén két erősen konzervált régiót tartalmaz: az N terminálison egy foszforhurok (P-loop), a C terminálison egy hidrofób motívum helyezkedik el. Ezen régiókra tervezett degenerált primerek felhasználásával többek közt az alábbi növényfajokból határoztak meg sikeresen RGA-kat: Arabidopsis (Arts és mts., 1998), kukorica (Collins és mts., 1998), bab (Creusot és mts., 1999), burgonya (Leister és mts., 1998), saláta (Meyers és mts., 1999), kajszi (Soriano és mts., 2005), és számos más termesztett növényfaj. 2006-ig több mint 1600 NBS-LRR típusú RGA izolálása történt meg (McHale és mts., 2006).

A teljes növényi genomszekvenciák alapján a legnagyobb számban jelenlévő csoport az R gének közül az NBS-LRR típusú rezisztenciagének csoportja (5. táblázat). Az ismert teljes genomszekvenciák alapján elmondható, hogy a szőlő 30434 (Jallion és mts., 2007), a nyár 45555 (Tuskan és mts., 2006), a lúdfü 27000 (Arabidopsis Genome Initiative, 2000), és a rizs 37544 fehérjét kódoló gént tartalmaz (International Rice Genome Sequencing Project, 2005). 
5. táblázat. A szekvenált növényi genomok becsült génszáma, génsürüsége és a NBS típusú gének mennyisége Velasco és mts. (2010) után.

\begin{tabular}{|l|c|c|c|}
\hline \multicolumn{1}{|c|}{ Faj } & Összes gén & Géngyakoriság/10kb & NBS gének száma \\
\hline Alma & 57386 & 0,78 & 992 \\
\hline Uborka & 26682 & 0,73 & 61 \\
\hline Szója & 46430 & 0,42 & 392 \\
\hline Nyár & 45654 & 0,94 & 402 \\
\hline Lúdfü & 27228 & 2,20 & 178 \\
\hline Szőlő & 33514 & 0,66 & 341 \\
\hline Rizs & 40577 & 0,97 & 535 \\
\hline Brachypodium & 25532 & 0,94 & 238 \\
\hline Cirok & 34496 & 0,47 & 245 \\
\hline Kukorica & 32540 & 0,15 & 129 \\
\hline
\end{tabular}

Az NBS-LRR típusú gének e négy faj esetében az összes feltételezett gén 1,51; 0,72; 0,53 illetve 1,23\%-át teszik ki (a felsorolt növények sorrendjének megfelelően). A számok alapján Yang és mts. (2008) megállapították, hogy a szőlő és a lúdfü esetében lényegesebben nagyobb arányban vannak jelen NBS-LRR típusú gének, mint a másik két növényfajban.

Yang és mts. 2008-ban két fásszárú faj - a szőlő és a nyár- esetében vizsgálták az NBS-LRR típusú géneket. Megállapították, hogy a TIR- és CC-NBS-LRR típusú rezisztenciagének eltérő felépítésűek lehetnek. Léteznek úgynevezett csonkolt $\mathrm{R}$ gének, melyeknek valamelyik doménje hiányozhat, vagy egyes domének akár többször is megjelenhetnek egy génen belül. A szőlőben összesen 495 NBS-LRR típusú gén található, amelyből 97 TIR-NBS-LRR típusú, beleértve az egyszerű TIR-NBS-LRR (90), és az eltérő felépítésű TIR-CC-NBS-LRR (1), TIR-NBS-LRR-TIR (3), TIR-NBS-LRR-TIR-NBS (1) és TIR-NBS-LRR-TIR-NBS-LRR (2) felépítésủ szekvenciákat. A szőlő genomja további 365 nem TIR-NBS-LRR típusú gént tartalmaz: CC-NBS-LRR (200), CC-NBS-NBS-LRR (2), CC-NBS-LRR-NBS-LRR (1), egy ismeretlen domént és NBS-LRR doméneket 
tartalmazó gén (147), valamint olyan NBS-LRR típusú gén, amelynek NBS doménje alapján feltételezhető, hogy a CC-NBS-LRR típusú csoportba tartozik, de CC doménje hiányzik (12). Ezen kívül ebben a növényfajban található összesen 76 olyan NBS típusú gén, amelyről hiányzik az LRR domén, beleértve azokat a géneket is, amelyeknek szekvenciája CC-NBS (26), TIR-NBS (14), valamint egy ismeretlen és egy NBS doménekből épül fel (36).

A nyárfa esetében az adatok azt mutatják, hogy összesen 78 TIR-NBS-LRR, 252 nem TIR-NBS-LRR, és 86 LRR régió nélküli NBS típusú gént tartalmaz a teljes genom.

Arabidopsis-on végzett vizsgálatok alapján Leister (2004) megállapította, hogy az NBS-LRR típusú gének tandem és nagyméretű kromoszóma részek duplikációjával sokszorozódnak. Zhou és mts. (2004) szerint két gén egy géncsaládba tartozik, ha az aminosavszekvenciájuk legalább 70\%-ban megegyezik, és a két illesztett nukleotidszekvencia legalább $70 \%$-os átfedésben van. Yang és mts. (2008) az NBS doménok illesztése alapján meghatározták, hogy a két vizsgált fásszárú faj esetében ezen kritériumok alapján mindkét faj esetében közel $78 \%$-a a vizsgált géneknek családokban helyezkedik el. Ez az arány Arabidopsis-nál és rizsnél 47,3 és 53,7 \%-ot ért el. Abban az esetben, ha az aminosavszekvencia azonosságát minimum $80 \%$-os értékben határozták meg, a két lágyszárú faj esetében a géncsaládok száma jelentősen csökkent: Arabidopsisnál 23,4 \%, rizsnél 11,4\%. Ezzel szemben a szőlő 67,9\%-os és a nyár 74,5\%-os értékei alapján az egyes géncsaládokba sorolható gének között nagyobb fokú az azonosság. Ennek alapján feltételezik Yang és mts. (2008), hogy a fásszárú növényeknél bekövetkezett génduplikációk játszottak szerepet az NBS-LRR típusú gének a genomban történő megsokszorozódásában.

\subsubsection{Rezisztenciagén-analógok izolálása Prunus fajokból}

A kórokozók elleni rezisztencia kulcsfontosságú szerepet tölt be a legtöbb csonthéjas nemesítési programban. A kajszi esetében a Plum pox potyvirus (PPV) által okozott kajszihimlő elleni rezisztencianemesítés fejlesztése érdekében különböző nemesítő csoportok foglalkoztak NBS-LRR típusú RGA-k izolálásával. Elsődleges céljuk a 'Stark Early Orange’ fajtából származó, rezisztenciához kapcsolt molekuláris marker fejlesztése volt. Dondini és mts. (2004) elsőként amplifikált, klónozott és csoportosított kajsziból származó RGA-kat az NBS domén konzervált régiói alapján. A klónozott inszertek restrikciós enzimekkel történő hasítása alapján ezeket öt különböző csoportba sorolta. 
Dondini és mts. (2004) a Shen és mts. (1998) által kidolgozott PCR stratégiát követték, mely során NBS-LRR típusú rezisztenciagének különböző konzervált motívumaira terveztek nem degenerált primereket. Csoportonként különböző mennyiségü, összesen 30 klónt szekvenáltak, melyek egyöntetüen a TIR-NBS-LRR típusú RGA csoportba tartoztak. Ezen szekvenciák illesztése alapján csoportonként primerpárokat terveztek a variábilis régiókra, és 17 különböző genotípuson tesztelték ezeket. A SEOBT101 primerkombináció csak a rezisztens fenotípusú egyedek esetében szaporított fel egy 300 bp hosszúságú DNSszakaszt, amit lehetséges eszköznek tekintettek a rezisztencia meghatározására.

Soriano és mts. (2005) az NBS doménre tervezett degenerált primerek alkalmazásával 43 egyedi következtetett aminosav-szekvenciát határoztak meg 'Goldrich' és 'Stark Early Orange’ PPV rezisztens fajtákból. A génszekvenciákat restrikciós hasítások alapján hat csoportba sorolták. A 43 következtetett aminosav-szekvencia mindegyike a TIR-NBS-LRR típusú csoportba tartozott. A csoportok variábilis szekvenciáira az $\mathrm{N}$ és $\mathrm{C}$ terminális irányába terveztek primereket, amiket az AFLP-RGA (Hayes és mts. 2000) technikához alkalmaztak. Ezeket a markereket a PPV-ellenálló heterozigóta 'Lito' fajta öntermékenyítésből származó $F_{2}$ hasadó populáció egyedein térképezték, de PPV rezisztenciához kapcsolt markert nem sikerült azonosítani. A 16 polimorf marker a korábban Vilanova és mts. (2003) által szerkesztett fizikai térkép 8 kapcsoltsági csoportja közül ötre térképeződött. Két lehetséges génklasztert határoztak meg a 6-os és 8-as kapcsoltsági csoporton, habár a DNS-szekvenciák alapján elmondható, hogy csak a 8. kromoszómán található régió tartalmaz stopkodon nélküli rezisztenciagén-homológokat. Az egyes kapcsoltsági csoportra térképezett markerek közül a Prunus davidiana-ból származó lisztharmat-rezisztencia lehetséges QTL-jéhez (quantitative trait loci) kapcsoltságot találtak, míg egy másik marker Vilanova és mts. (2003) által PPV rezisztenciáért felelős régióval mutatott kapcsoltságot.

A különböző RGA-családokra tervezett markerek több esetben azonos régiókba találhatók meg, ami megegyezik a Baldi és mts. (2004) által alma RGA vizsgálatakor megfigyelt jelenséggel, miszerint a fizikai távolság és filogenetikai távolság között korreláció van.

A kajszi esetében tapasztalt TIR-NBS-LRR és CC-NBS-LRR típusú RGA-k megjelenésének egyenlőtlen eloszlását összehasonlítva megállapították, hogy a vizsgált kétszikűeknél ez egyedülálló jelenség. Ezt azzal magyarázták, hogy a kajszi genomjában 
valóban aránytalanul kis számban vannak jelen a CC-NBS-LRR típusú szekvenciák vagy az alkalmazott PCR technika nem megfelelő azok kimutatására (Soriano és mts. 2005).

Lalli és mts. 2005-ben összesen 42 RGA-t határoztak meg és térképeztek, amelyek az NBS-LRR, kináz, transzmembrán domén, patogénválasz (PR) proteinek és rezisztenciával kapcsolt transzkripciós faktorok közé tartoztak. Az RGA-k fizikai térképezését a BAC könyvtárakhoz való hibridizácival, térképező populáció nélkül végezték el. Számos próba olyan BAC klónokhoz hibridizált, amelyeken korábban már azonosítottak lisztharmat-rezisztencia QTL-eket. Ezen túl 3 amplifikált RGA a 7. kromoszómára a $M a$ gént tartalmazó régióba, míg másik 2 RGA a 2. kromoszómára, a RMai génnel mutatott kapcsoltságot. Mindkét gén fonálféreg-rezisztenciát biztosít Prunus fajokban.

Két RGA szekvencia kapcsoltságát mutatták ki Decroocq és mts. (2005) által meghatározott 1. és 7. kromoszóma Sharka rezisztencia QTL-jeivel. Nem találtak azonban a 6. kromoszómán elhelyezkedő, legerősebb hatású Sharka rezisztenciáért felelős QTLekhez kapcsolt szekvenciákat. Több RGA klónt térképeztek az 1. kromoszómának arra a régiójára, ahova Vilanova és mts. (2003) a Sharka rezisztenciát lokalizálták. A 3. kivételével az összes további kromoszóma tartalmazott RGA-kat. Összesen 26 NBS-LRR típusú RGA-t térképeztek őszibarackon, és ebböl mindössze kettő volt CC-NBS-LRR típusú. Az illesztések mindkét NBS-LRR típusú csoport jelenlétét bizonyítják, de többségében TIR-NBS-LRR típusú RGA-kat izoláltak. Ezt az egyenlőtlen eloszlást őszibarack esetében azzal magyarázták, hogy a TIR-NBS-LRR típusú RGA-k nagyobb számban fordulnak elő a genomban, esetleg az amplifikáció során alkalmazott primerek ezeket a szekvenciákat nagyobb valószínüséggel szaporítják fel. A Prunus genomban a két csoport más régiókba térképeződött, hasonlókép, mint a lucernában és a szójában. Ezzel szemben az Arabidopsis-ban egy klaszterben mindkét csoportot térképezték Meyers és mts. (1999). A szőlő genomszekvencia alapján Velasco és mts. (2007) nem találtak arra példát, hogy a két csoport génjei egy klaszteren belül fordultak volna elő.

\subsubsection{RGA markerek kapcsoltsága növényi rezisztenciákkal}

A molekuláris markerek azonosítása két stratégia alapján történhet. A homológiára alapozott marker készítésekor, primerek a már ismert szekvenciák alapján konzervált szakaszokra tervezhetők. Ezeket a markereket, amelyek már adott funkciójú gének szekvenciája ismeretében készülnek Andersen és Lübberstedt (2003) funkcionális 
markereknek nevezte el. A második stratégia a szekvencia ismeret nélküli, véletlenszerü markerezési (RAPD, AFLP, ISSR stb.) technikák alkalmazása. A funkcionális RGA markerek használata elsősorban a fás szárú növények rezisztencia vizsgálatakor terjedt el, mert ezeknél a fajoknál térképező populációk hiányában ez a stratégia járhat sikerrel.

Az RGA markereket elsőként szőlőn Di Gaspero és Cipriani (2002) alkalmazta a peronoszpóra-rezisztencia vizsgálatára sikerrel. A három vadfaj (V. amurensis, V. riparia, $V$. cinerea,) és ellenálló interspecifikus hibridekben ('Seyval', 'Regent', 'Bianca') sikerült egy specifikusan megjelenő markert kimutatniuk, ami hiányzott a peronoszpóra-fogékony európai fajtáknál.

Donald és mts. (2002) szőlő lisztharmat rezisztencia vizsgálatakor három NBS típusú RGA markert azonosított a Muscadinia rotundifolia fajból származó Run 1 lókuszhoz kapcsoltan. A hasadó populáció 167 egyedén térképezték a markereket, két marker teljesen kapcsolt volt a Run 1 génnel, míg a harmadik marker 2,4 cM távolságra helyezkedett el.

Calenge és mts. (2005) almából határoztak meg NBS típusú RGA szekvenciákat. A Vr 2 ventúria rezisztenciagénnel talált kapcsoltságot a második kapcsoltsági csoportban, a Pl-w lisztharmat rezisztenciát tartalmazó régióba három NBS RGA markert sikerült térképezniük. A 'Durello di Forli’ almafajtából származó $V d$ ventúria rezisztenciagénnel négy marker mutatott kapcsoltságot.

\subsection{Poligalakturonáz-gátló fehérjék}

A növényi sejtfal egy összetett polimer vegyületekből álló rendszer, ami a sejtek elválasztást és szilárdítását biztosítja. A növényi sejtfal öt alapvető polimer vegyületből épül fel: cellulóz, hemicellulóz, pektin, glikoprotein, lignin. A sejtfal tulajdonképpen cellulóz mikrofibrillumok szövedéke, amely hemicellulózból és pektinböl álló mátrixba ágyazódik be. A pektin típusú poliszacharidok minden magasabb rendü növényben előfordulnak, kétsziküekben az elsődleges sejtfal $35 \%$-át teszik ki, míg egysziküekben csak 2-3\%, és a sejtfal elemeinek összetartásáért felelős vegyületek (Albersheim és mts., 1969). A pektint két fó polimer vegyület alkotja: homogalakturonán ( $\alpha-1-4$ kapcsolódású galakturonsav), ramnogalakturonán (galakturonsav és ramnóz 2-4 kapcsolódása eltérő arabinóz és galaktóz oldaláncokkal). Ezek az elsődleges sejtfal középlemezét alkotják. A fiatal sejtfal elsősorban poliszacharidokból épül fel kis fehérje tartalom mellett, ami későbbiekben lignifikálódhat (Evert, 2006). Feladatai eltérőek, a sejt ozmotikus 
nyomásával szembeni tartásával egyben a sejtek alakját is meghatározza, a növényi szövet szilárdságát adja, és a szállítórendszer falát alkotja. A sejtfal fontos szerepet tölt be a kórokozókkal szembeni ellenállóságban, mint elsődleges fizikai gát, és mint a lebontó enzimek terjedésének gátja (Albersheim, 1965). A növényi szövetek kórokozó általi kolonizálásának első lépése a mikrofibrillumokat kötő pektin poliszacharidok macerációja, lebontása. Poliszaharid bontó enzimeket a növények (Agrawal és Bahl, 1968), a gombák (Albersheim 1965) és a baktériumok (Ghuysen, 1968) egyaránt termelnek. A növényi kórokozók képesek enzimeikkel a növényi sejtfal poliszaharidjainak bontására (Albersheim és mts., 1969). Byrde és Fielding (1968) az alma monilia fertőzésben a kórokozó pektinbontó enzimeinek szerepét bizonyította, ezek a fertőzési folyamatnak kulcsszereplői.

A kórokozó gombák meghatározott szénforrást tartalmazó táptalajban nevelve, a táptalajba az adott poliszaharidot bontó enzimet választják ki. A kórokozó gombák fejlödésük során meghatározott sorrendben választják ki a sejtfal bontásáért felelős enzimeket, amit Albersheim és mts. (1969) a Colletotrichum lindemuthianum, Jones és mts. (1971) Fusarium oxysporum f.sp. lycopersici fajok vizsgálatakor igazolt. Mindkét esetben az endo-poligalakturonáz (PG) volt az elsőként termelt enzim. Ezek az enzimek kitisztítva megörizték azt a tulajdonságukat, hogy különböző növényi sejtfalakról leemésztik a galakturonsavat. A poligalakturonáz enzimek képesek a növényi sejtfal pektinjeinek lebontását megkezdeni, e nélkül a sejtfal szerkezetét megváltoztató enzim nélkül a később szekretálódó poliszaharid-lebontó enzimek nem képesek a sejtfal pektinjeinek lebontására (Karr és Albersheim, 1970).

A növényi sejtfalból izolált fehérjék nem voltak hatással a C. lindemuthianum kórokozó gomba $\alpha$-arabinozidáz, $\alpha$-galaktozidáz, metil-celluláz, xilanáz, exopoligalakturonidáz poliszaharid bontó enzimeire, viszont az endo-poligalakturonáz enzim hatásának gátlását figyelték meg (Albersheim és Andersona, 1971).

Gyümölcsfertőzési kísérletek során az extracelluláris pektolitikus gombaenzimek gátlását Byrde és mts. (1960) polifenolos vegyületek oxidáló hatásával magyarázzák. Mivel Fisher és mts. (1973) egyértelműen bizonyítják, hogy az általuk vizsgált fehérje a pektolitikus enzimek közül csak a PG-t gátolja, a korábban pektolitikus enzimek általános fenolos vegyületekkel történő gátlásától a folyamatot egyértelműen elkülönítették. 
A jelenséget Fielding (1981) szilva, őszibarack, alma, körte, szőlö, moniliás és botritiszes gyümölcsfertőzésekor is megfigyelte. A kísérletben kivételt képzett a nem oxidatív módon fertőző Penicilium sp. (fenoláz-inhibitorokkal fertőző gomba), amely esetében nem volt PG-gátlás kimutatható a fertőzött almagyümölcsökből. A monilia és botritisz fertőzött gyümölcsök kivonatából nem volt kimutatható PG aktivitás, míg a fehérjekivonat izoelektromos fókuszálását követően a korábban is meghatározott izoelektromos ponton (pI 9-10) a poligalakturonáz aktivitás ismételten megjelent. A gátló vegyület 20 perces hökezelés hatására, 40-70 C között, az enzimaktivitás folyamatosan csökkent, 100 C-on 5 perces kezelés az enzim aktivitását felére csökkentette.

Tripszines emésztés során a vegyület PG-gátló képessége megszűnt, így legalább egy fehérjealkotót valószínűsít Fielding (1981). Fontos megállapítás, hogy fertőzetlen gyümölcsmintákban nem volt kimutatható PG-gátló aktivitás, de ezek alapján nem volt eldönthető, hogy a fertőzés hatására keletkezik-e ez a vegyület, avagy folyamatosan megtalálható a szövetekben, de fertőzés hatására aktiválódik. A Botrytis cinerea PG enzimének gátlásáról számol be körte esetében Abo-Goukh és mts. (1983), és megállapítja, hogy a PGIP a körte érése folyamán termelődő endogén PG enzimére nincs hatással.

Babból Cervone és mts. (1987) izolálták az endo-poligalakturonázt gátló fehérjét (PGIP) és megállapították, hogy a PG-PGIP között kialkuló komplex eredményeként a PG enzim aktivitása teljes mértékben megszűnt. Később Cervone és mts.(1989) a PG enzim aktivitás gátlása mellett megállapították, hogy a pektin teljes hidrolízisének hiányában keletkező oligogalakturonsav származékok fitoalexin szerepet tölthetnek be. A sejtfal mátrixát alkotó pektin emésztéséből származó poliszaharidok hatására a zöldborsó hüvelyében a pisatin gombagátló fitoalexin akumlálódott (Walker-Simons és mts. 1983). A pektin emésztéséből származó oligogalakturon vegyületeket a bab és Colletotrichum lindemuthianum gazda patogén rendszerben aktív fitoalexinként határozták meg De Lorenzo és mts. (1990). Kísérleteik szerint három eltérő patogenitású Colletotrichum lindemuthianum izolátum azonos mértékben termelte az endo-poligalkturonáz enzimet, amik a pektinből elicitor aktív oligogalakturon sav származékokat emésztett le. Négy eltérő Colletotrichum fogékonyságú babfajtából ('Great Northern', 'Pinto', 'Red Kidney’, 'Small Red') izolált PGIP fehérjék egységesen növelték az oligogalakturonsav származékok életidejét, a négy fajta PG aktivitásának gátlása között nem tapasztaltak eltérést. A négy eltérő érzékenységü babfajta PG-PGIP fehérjének kapcsolata, önmagában nem magyarázza 
a fajták és kórokozó között megfigyelhető raszspecifikus rezisztenciát (De Lorenzo és mts. 1990).

A bab PGIP enzimének tripszines emésztésével Toubart és mts. (1992) aminosavszekvencia szakaszokat határoztak meg. A gén 758 bp hosszúságú szakaszának klónozása az aminosavszekvencia alapján tervezett degenerált primerek alkalmazásával történt. A génszakaszt egy bab genomi könyvtárhoz hibridizálták és kiválasztották a PGIP gént tartalmazó klónt, meghatározták a 3,3kB klón szekvenciáját. A genomi klón egy folyamatos leolvasási kerettel rendelkező 1026 bázispár (342 aminosav) hosszúságú gént tartalmazott. Sem a nukleotid-, sem a transzlált aminosavszekvencia nem mutatott hasonlóságot semmilyen addig ismert nukleotid- és aminosavszekvenciával. Mindegyik vizsgált szövetrészből (levél, szár, kallusz és virág) kimutatták a gén kifejeződését. A folyékony kultúrában nevelt kalluszokból a Northern-analízis során sokszorosan erősebb jelet kaptak a többi szövetrészhez képest. A cDNS klónok szekvenciája alapján megerősítették, hogy a gén nem tartalmaz intronokat. Stotz és mts. (1993) körtéből izolálták a PGIP gént és megállapították, hogy a Toubart és mts. (1992) által meghatározott bab PGIP gén aminosav-szekvenciájával $50 \%$-os egyezést mutat. A két gén az $\mathrm{N}$ terminálison egy feltételezhető szignálpeptid konzervált motívumban megegyezik. A gén két kópiában található meg a körtegenomban. A PGIP enzimről egyértelmủen kimutatták, hogy egy glikoprotein és meghatározták az enzim glikozid részének összetételét. A gén kifejeződését a virágban és gyümölcsben mutatták ki, míg a levélszövetből nem. Az enzim aktivitása a gyümölcsben 200-szorosa volt a virágban mért aktivitásnak.

A bab PGIP paralóg génjei eltérő hatékonyásággal képesek gátolni a különböző gombafajok PG enzimeit. A Botrytis cinerea PG enzimeit mindegyik bab PGIP fehérje képes gátolni, de eltérő hatékonysággal, míg a Fusarium moniliforme faj PG enzimére kizárólag a PvPGIP2 gén hat. A két gén fehérje terméke között összesen nyolc aminosav eltérés van.

A PvPGIP2 génnek a nyolc aminosav egyenként irányított mutagenézissel történt cseréje $P v P G I P 1$ gén szekvenciájára azt eredményezte, hogy minden esetben csökkent gátló hatást állapítottak meg a $F$. moniliforme PG gátlásában (Leckie és mts. 1999). A bab $P G I P 1$ enzimének 253 pozícióban található bázikus lizin glutaminra történő cseréje, a $F$. moniliforme PG enzim gátlását eredményezte. Ezek alapján megállapítható, hogy a PGIP gén kifejeződésének mértéke és a gén változatok együtt biztosíthatják a PGIP gének rezisztenciában betöltött szerepét. 
Stotz és mts. (1994) paradicsom termésböl izolálták a PGIP fehérjét. A körtéböl és paradicsomból származó PGIP fehérjék a szürkerothadást okozó polifág Botrytis cinerea poligalakturonáz enzimaktivitásának gátlásakor a körtéből származó enzim 20-szoros gátló hatással rendelkezett a paradicsom PGIP fehérjéhez képest (Stotz és mts. 1993). A paradicsomból izolált cDNS szekvenciája alapján a bab PGIP aminosavszevenciájával 68\% azonosságot, míg a körte PGIP aminosav szekvenciájával 50 \%-os azonosságot mutatott. A szekvencia analízis során elsőként ismerték fel, hogy a PGIP gén tandem leucin gazdag ismétlődéseket (LRR) tartalmaz. A LRR régióról már korábban bizonyították, hogy fehérje-fehérje interakciókért lehet felelös, így a PG-PGIP összekapcsolódásának tényét ez megerősítette. Az első PGIP génnel történt sikeres transzformációs kísérletet Powell és mts. (2000) végezték el, a körte PGIP génjét építették paradicsom növénybe. A kontroll növényhez képest a paradicsom terméseken $15 \%$-kal, levélen $25 \%$-kal csökkent a Botrytis cinerea kártétele a transzformáns növények esetében. Később Arabidopsis (Ferrari és mts., 2003) szőlő (Aguero és mts., 2005), dohány (Joubert és mts., 2007) esetében bizonyították transzgénikus kísérletekkel a PGIP szerepét a növénypatogén PG gátlásában.

A PGIP gének expressziójának változását ventúria fertőzés hatására körte esetében Faize és mts. (2003) vizsgálták. Az ellenálló körtefajták estében bizonyították, hogy a gén expressziója gyorsan (fertőzést követő nap) négyszeresére nőtt meg a fertőzés előtti állapothoz képest, és a két ellenálló fajta PGIP enzimei 3-4 szeres gátló hatását okozták a ventúria PG enzimének. Oliveira és mts. (2010) vizsgálták Sclerotinia sclerotiorum fertőzés hatására a PGIP gének expressziójának változását babon. A négy kópiában szereplő gén alléljai eltérő időpontokban és eltérő intenzitással expresszáltak a fertőzés hatására. A mechanikai sebzés hatására kizárólag egyetlen lókuszról származó allélok expresszáltak. A bab PGIP génjeinek megnövekedett expresszióját sebzés, oligogalakturonsav származékok és gombákból származó glukanázok okozták (Bergmann és mts. 1994).

Alma gyümölcsben a PGIP gén expressziója az érettség alapján változott, ami a Yao mts. (1999) szerint a gén a gyümölcsfejlődés során szabályozottan expresszál. A Penicillium expansum és Botrytis cinerea fertőzött gyümölcshúsban PGIP gének megnövekedett expresszióját tapasztalták, míg a fertőzetlen húsrészben nem emelkedett a gén kifejeződése. A gyümölcshús sebzésekor kisebb mértékű volt az expresszió változása mint a gombafertőzés hatására bekövetkezett növekedés. Az egy hónapos $0{ }^{\circ} \mathrm{C}$ 
hőmérsékleten történő tárolási kísérlet során folyamatosan nőtt a PGIP gén expressziója az érett gyümölcsben. Ez alapján nemcsak a patogének ellen, hanem a gyümölcsfejlődés szabályzásában is szerepet játszik a PGIP fehérje (Yao és mts. 1999).

Az élővilágban megtalálható LRR proteineket Kajava (1998) legkevesebb hat eltérő csoportba sorolta, amik egymástól független evolúciós eredettel rendelkeznek. A növényvilágban elterjedt extracelluláris LRR fehérjék konzervált szekvenciája: xxLxxLxLxxNxL(T/S)GxIPxxLGx (Kajava, 1998). Több LRR ismétlődés szükséges egy domén létrehozásához, aminek szerkezet patkó alakjához hasonlít. A fehérje belső oldalán helyezkednek el a $\beta$-lemezek egymással párhuzamosan, míg a fehérje külső oldalán az $\alpha$ hélixek találhatók (Kobe és Deisenhofer, 1995).

A bab PGIP kristály szerkezetének vizsgálatakor Di Matteo és mts. (2003) megállapították, hogy a fehérje 10 LRR ismétlődésből áll. Az LRR ismétlődésekben két $\beta$ redő után egy $\alpha$-hélix következik (5. ábra). A fehérje belső konkáv oldala negatív töltésű, ami a PG enzim megkötését szolgálhatja. A Fusarium moniliforme poligalakturonáz pozitív töltésü aminosavainak (Arg-267 és Lys-269) kulcs szerepe van a PGIP2 enzim negatív töltésü részeihez történő kötödéskor.

(a)

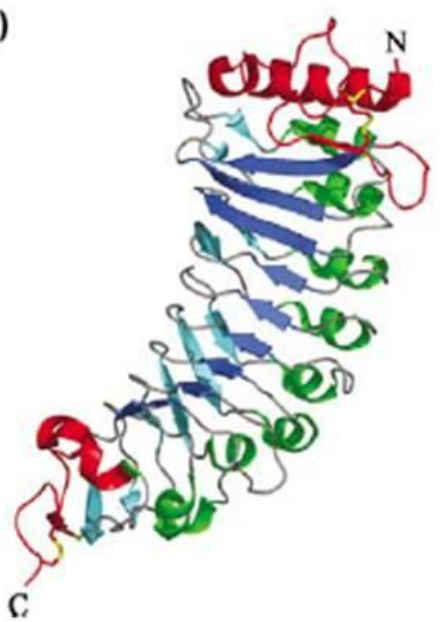

(b)

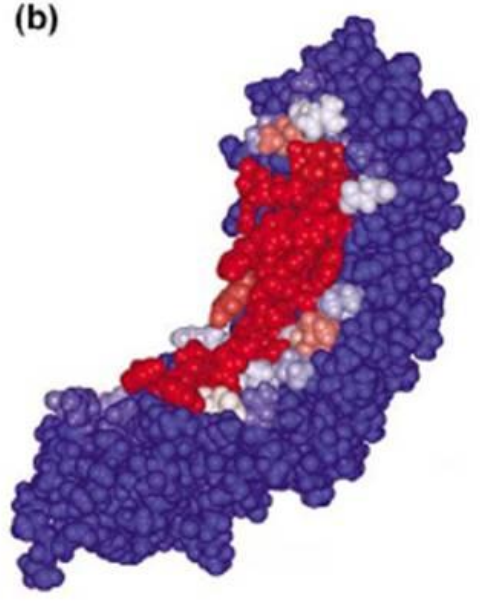

(c)

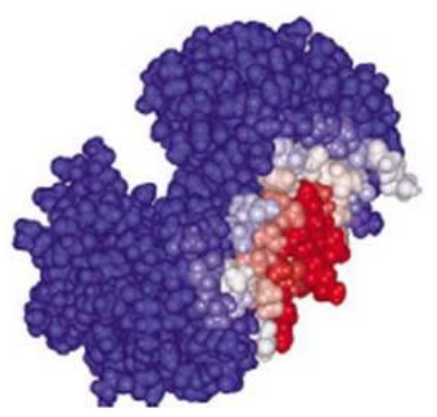

5. ábra. $P v P G I P 2$ és a $F$. moliniforme $\mathrm{PG}$ fehérjék kristályszerkezete. 'a' kép: Szalagmodell ábrázolja a fehérje szerkezetét. Piros szalag az $\mathrm{N}$ és $\mathrm{C}$ terminálison található ciszteinben gazdag domént jelöli. Mindkét domént két diszulfidhíd köti a szolenoid szerkezetéhez. A központi extracelluláris domént tíz tandem ismétlődésü 24 aminosav hosszúságú LRR alegység alkotja. Három alegységből épül fel az eLRR rész. A fehérje belső (konkáv) oldalán a kékkel jelzett $\beta$-redő, a szolenoid külső oldalán találhatók a zöld spirállal jelölt $\alpha$-hélixek. Türkizkékkel a két oldal közti térben található nem szokványos $\beta$-redöket jelölték. 'b' kép: Pirossal jelölték fehérje kötésre képes részeket a fehérjén. 'c' kép: A $F$. moliniforme PG enzim kristályszerkezete, amin a fehérje-fehérje kapcsolódást kialakító részt piros színnel jelölték (Federici és mts., 2006). 


\section{ANYAG ÉS MÓDSZER}

\subsection{Növényanyag}

A vizsgált fajták és hibridek a Budapesti Corvinus Egyetem Genetika és Növénynemesítés Tanszék szigetcsépi kajszi ültetvényéből származnak (6). Az ültetvényt 1990 és 2000 között telepítették 5x4 méteres térállásban, alanyként cseresznyeszilva magoncokat használtak. A mesterséges vesszőfertőzés a tanszék soroksári ültetvényében történt. A fertőzés a 'Korai zamatos' és 'Zard' fajták, és ezeknek 2003-ban történő keresztezéséből származó 48 utódon történt.

6. táblázat. A munkánk során vizsgált kajszi, cseresznyeszilva és japánszilva fajták és hibridek

\begin{tabular}{|c|c|c|}
\hline Fajta neve & Származása & Nemesítő által megadott pedigreé \\
\hline Aurora & USA & RR17-62 × NJA-13 / Rutbhart \\
\hline Baneasa 4/11 & Ro. & Ismeretlen \\
\hline Ceglédi arany & Mo. & Rózsabarack C. $1668 \times$ Ceglédi óriás; 1994 \\
\hline Ceglédi bíborkajszi & Mo. & Véletlen magonc; 1953 \\
\hline Ceglédi óriás & Mo. & Tájszelekció, Izsák; 1953 \\
\hline Ceglédi Piroska & Mo. & Ceglédi óriás $\times$ Magyarkajszi C. 1789; 1995 \\
\hline CR-2-63 & USA & Ismeretlen \\
\hline Effekt & Ukrajna & Krupnoplodnij szabadmegporzású magonca \\
\hline Goldrich & USA & Sunglo $\times$ Perfection \\
\hline Gönci magyarkajszi & Mo. & Magyarkajszi szelektált klónja; 1960 \\
\hline Harcot & Kanada & $\begin{array}{l}(\text { Geneva } \times \text { Narmata }) \times \text { Morden } 604 \times \text { NJA1 } \\
(\text { Perfection } \times \text { Phelps }) ; 1977\end{array}$ \\
\hline Harmat & Mo. & Salah szabadmegporzású magonca; 2002 \\
\hline Karola & Szlovákia & Kloboucka $\times$ Velkopavlovicka \\
\hline Kecs-psar & Üzbegisztán & Helyi fajta Közép-Ázsiában; Kosztina, 1930 \\
\hline Konkurencia & Ukrajna & Effect $\times$ Priuszadebnij rannij \\
\hline Konzervnij pozdnij & Ukrajna & Véleltlen magonc \\
\hline Korai zamatos & Mo. & Jubilar szabadmegporzású magonca; 2002 \\
\hline Magyarkajszi C.235 & Mo. & Magyarkajszi szelektált klónja \\
\hline Mamaia & Románia & $\begin{array}{l}(\text { Ananas } \times \text { Ananas }) \times(\text { Tarzii de } \text { Bukuresti } \times \\
\text { Ananas); } 1985\end{array}$ \\
\hline Mandulakajszi & Mo. & Ismeretlen; 1954 \\
\hline Marculesti 18/6 & Románia & Ismeretlen \\
\hline Mari de Csanad & Románia & Ismeretlen eredetű helyi fajta \\
\hline Nikitszkij & Ukrajna & Krasznoscsokij szelektált klónja \\
\hline
\end{tabular}




\begin{tabular}{|c|c|c|}
\hline \multicolumn{3}{|l|}{ 6. táblázat folytatása } \\
\hline NJA-8 & USA & Ismeretlen \\
\hline Orange red & USA & Lasgerdi Mashhadi x NJA2 \\
\hline $1 / 33$ & Mo. & P. cerasifera $\times P$. vulgaris \\
\hline P. dasycarpa & & P. cerasifera $\times$ P.armeniaca spontán hibrid \\
\hline P. salicina 'Methley' & USA & P. salicina $\times P$. cerasifera \\
\hline P. cerasifera & & magonceredetü alany \\
\hline P. salicina 'Burbank' & USA & P. salicina Burbank Luther által szelektált magonc \\
\hline Pannónia & Mo. & Magyarkajszi $\times$ Borsi-féle kései rózsa \\
\hline Pisana & Olaszország & ICAPI 26/5 szabadmegporzása; 1995 \\
\hline \begin{tabular}{|l} 
Priuszadebnij rannij \\
\end{tabular} & Ukrajna & Szamarkandszkij rannij x Krasznoscsokij \\
\hline Sulmona & Románia & $($ Luizet $\times$ Umberto $) \times($ Ananas $\times$ Ananas $)$ \\
\hline Venusz & Románia & $($ Umberto $\times$ Ananas $) \times($ Luizet $\times$ Umberto $)$ \\
\hline Zard & Üzbegisztán & Zardalju szabadmegporzású magonca \\
\hline
\end{tabular}

\subsection{Szabadföldi természetes fertôzés megfigyelése}

A szabadföldi természetes fertőzés megfigyelése a szigetcsépi ültetvényében történt három vegetációs időszakban. A vizsgálat első két évében történt védekezés a virágzáskori moniliás betegséggel szemben, fehérbimbós stádiumban és teljes virágzáskor Topas 100 EC penkonazol hatóanyagú gombaölőszerrel (0,5 1/ha). A fertőzés mértékének felvételezése minden évben sziromhullást követően öt héttel történt, intenzív hajtásfejlődéskor. A betegség kategóriákat a teljes termőrészpusztulás százalékos értékének megfelelően alakítottuk ki (7. táblázat). Fajtánként legalább 4 egyedet vizsgáltunk legalább három éven keresztül, az ennél kevesebb egyeddel rendelkező genotípusokat nem értékeltük.

A $P$. mume, $P$. sibirica természetes vesszőfertőzését az MTA ÖBKI Vácrátóti Botanikus Kertjében található egyedeken tanulmányoztam 2009-2011 között. 
7. táblázat. Monilia fertőzöttség bonitálási kategóriái

\begin{tabular}{|c|c|}
\hline Betegség kategóriák & Elpusztult termőrészek (\%) \\
\hline 0 & 0 \\
\hline 0,5 & $6-10$ \\
\hline 1 & $11-15$ \\
\hline 1,5 & $16-20$ \\
\hline 2 & $21-25$ \\
\hline 2,5 & $>26$ \\
\hline 3 & \\
\hline
\end{tabular}

\subsection{Fertőzési kísérletek}

\subsubsection{Szabadföldi virágfertőzési és megporzási kísérletek}

A mesterséges virágfertőzési kísérletek a szigetcsépi ültetvényben történtek. Két genotípus esetében a 'Kecs-psár' és 'Goldrich' fajta fáin fehér bimbós állapotban egész ágak összes virágát kasztráltuk, ami a szirmok és a porzók mechanikai eltávolítását jelentette. A kasztrált ágak felét 'Pannónia' fajta pollenjével poroztuk be, míg az ágak másik felét megporozatlanul hagytuk. Ezzel párhuzamosan kijelöltünk kezeletlen szabadelvirágzású ágakat pozitív kontrollként mindkét vizsgált fajtán. A kasztrálást követő napon az ágakat 500 konídium/ml szuszpenzióval permeteztük le. A vizsgált ágakon a monilia fertőzést teljes sziromhullást követően egy héttel felvételeztük, megszámoltuk a fertőzött és ép virágok számát. A növényvédelmi kezeléstől a vizsgált ágakat fóliatakarással óvtuk. Az elpusztult vesszőrészekből a kórokozót burgonya dextróz agar (PDA, Duchefa) táptalajon izoláltuk vissza, és a táptalajon fejlődő gombatelep morfológiája alapján azonosítottuk.

\subsubsection{Mesterséges vesszőfertőzés}

A mesterséges fásrészek fertőzését elsőként a Crossa-Raynaud (1969) módszerével kíséreltük meg. A virágzás után két héttel két-három éves levágott ágakat fertőztünk a háncsszövetben ejtet sebeken $M$. laxa által átnőtt PDA korongokkal és nedves környezetben tartva inkubáltuk. Az ellenálló 'Zard' fajta levágott kétéves ágainak mesterséges próbafertőzéseket követően azt tapasztaltuk, hogy az ágak teljes hosszán a háncsrész elpusztult, ezért ezt a fertőzési technikát nem alkalmaztuk. A továbbiakban 
ennek a technikának egy, az egyéves vesszők fertőzésére átalakított változatát kíséreltük meg elvégezni. A vizsgálathoz az ellenállóságot mutató 'Zard' és erősen fogékony 'Korai zamatos' fajták egy-egy példányát és ezek keresztezéséből származó 48 egyedből álló utódpopulációját használtuk. A mesterséges vesszőfertőzési kísérleteket a Budapesti Corvinus Egyetem Genetika és Növénynemesítés Tanszékének soroksári kajsziültetvényében végeztük 2009. szeptemberében és 2011. októberében. Fánként legalább öt vesszőn két-két pontban 3-7 mm hosszú sebzést ejtettünk a levélalappal szemben és a vessző háncsszövete alá $M$. laxa által kolonizált $2 \mathrm{~mm}$ átmérőjü táptalaj korongot helyeztünk, majd fóliával tekertük be. A fertőzés kiértékelése 2010. januárjában 15 héttel a fertőzés után, és 2011. novemberében 8 héttel a fertőzést követően a vesszők begyüjtésével és feldolgozásával folytatódott. Az elhalt szövetrész hosszát és a fertőzési helynél a vessző átmérőjét tolómérővel mértük meg, a vessző háncsszövetének történő felvágását követően. A 2 mm-nél vastagabb vesszőknél mintánként megmértük az elpusztult szövet hosszát és kiszámítottuk az így nyert adatok átlagát. . Statisztikailag összehasonlítottuk a fenti értékeket a fertőzést követő szöveti elváltozások jellemzői alapján fogékonynak vagy ellenállónak ítélt egyedek esetében. A statisztikai tesztek előfeltételeit (adatok normál eloszlása, varianciák homogenitása) ellenőriztük, ezek eredményei alapján, ahol kellett, nem-parametrikus tesztet alkalmaztunk. Ezek az adatok normál eloszlását nem igénylő Mann-Whitney-teszt és varianciák homogenitását nem igénylő Welch-teszt voltak. A szülő és utódok fertőzött vesszőin vizsgáltuk a fertőzött vesszők hosszának és a vesszők átmérőjének korrelációját. Mivel a parametrikus Pearsonkorreláció egyik előfeltétele (adatok normál eloszlása, Shapiro-Wilk teszt $\mathrm{p}<0,05$ ) nem teljesült, ezért nem parametrikus Spearman-korreláciot végeztünk. Az analízisek a Statistica 8.0 szoftver segítségével készültek.

\subsubsection{Laboratóriumi kísérletek}

A virágrészek érzékenységét a Monilinia laxa kórokozóval szemben 0,5\% agar (szirom) illetve 1/2 PDA (bibe és porzószálak) táptalajra helyezve vizsgáltuk. Az ültetvényből begyüjtött bimbós vesszőket, ágakat üvegházban hajtattuk meg és a felnyílás előtti virágokról a szirmot, bibét és a porzószálakat a vacokkal együtt virágról leválasztva petricsészébe helyeztük sötétbe, $10^{\circ} \mathrm{C}$-ra. A sziromfertőzést $10 \mu \mathrm{l}$ szuszpenzióval (10 konídium/ $\mu$ l) a szirom színi oldalán végeztük. Negatív kontrollként desztillált vizet alkalmaztunk. A bibe és porzószálak fertőzésekor a PDA táptalajon fejlődő micélium elé 
helyeztük a virágrészeket. A bibéből kiválasztódó ribonukleázok kimutatását agar táptalajon Halász (2007) leírása alapján végeztük.

A micélium fejlődésének vizsgálatakor a 'Ceglédi óriás' virágainak kinyílása előtt a bibéit $200 \mu$ l-es csőbe helyeztük lefelé ( $3 \mathrm{db} /$ cső) és $50 \mu 1$ desztillált vizet pipettáztunk rá. Egy éjszakán át $20{ }^{\circ} \mathrm{C}$-on rázattuk $50 \mathrm{rpm}$-mel. Folyékony táptalajként friss burgonya főzőlevét használtuk. $50 \mathrm{~g}$ friss hámozott burgonyát $500 \mathrm{ml}$ vízben megföztünk és $70 \mathrm{~g} / \mathrm{m} 2$ szürőpapíron keresztül megszürtük. $500 \mu 1$ folyékony táptalajhoz $25 \mu$ l bibekivonatot adtunk. A micélium fejlődését a kísérlet 12., 24., 72. órájában vizsgáltuk meg fénymikroszkóppal.

A levélfertőzési kísérletnél két héttel a sziromhullást követően zöld hajtásokat gyüjtöttünk a 'Zard' és 'Orange red' fajtákról és ezekről 20-20 darab 3-8 cm hosszúságú levelet desztillált vízzel nedvesített szürőpapírra helyeztük Petri-csészékbe.. A lezárt Petricsészéket fényszekrénybe $\left(20^{\circ} \mathrm{C}, 12\right.$ órás megvilágítottság) helyeztük. Ezt követően a levelek turgorának kialakulásakor a levéllemezek közepére, színi oldalon $6 \mathrm{~mm}$ átmérőjü M. laxa által átszőtt agarlemezt helyeztünk, kontrollként steril agarlemez korongokat helyeztünk mindkét fajta 5-5 levelére.

\subsubsection{Mikroszkópos vizsgálatok}

A mesterségesen és természetesen fertőzött növényi részeket Leica MZ6 sztereomikroszkóppal, Carl Zeiss Jena Jenalumar fénymikroszkóppal és a BCE Központi Laboratóriumában Tesla BS 300 típusú pásztázó elektromikroszkóppal vizsgáltuk. A minták előkészítése a központi laborban az alábbi protokoll szerint történt. A virágmintákat $5 \%$-os glutáraldehidben történő három órás kezelés után, $1 \%$-os ozmium-tetroxidos áztatás követte két órán át. A dehidrálást, egyre töményebb, majd végén abszolút acetonnal végeztük. A minták acetontól történő tisztítása 7,2 pH-ju foszfátpufferrel történt. A szárítás CPD 020 típusú készülékben végeztük egy éjszakán át. A minták felületének vezetőképességét 30nm vastag aranyréteg felvitel biztosította, amit CPD 040 típusú katódporlasztó készülékkel végeztünk. A virágrészeket elektronmikroszkóp alatt értékeltük, s a fertőzési pontokról fényképfelvételeket készítettünk 25-4000-szeres nagyítással. 


\subsection{Molekuláris vizsgálatok}

\subsubsection{DNS- alapú kísérletek}

\subsubsection{DNS-izolálás}

A genomi DNS izolálása teljesen kifejlett fiatal levelekből történt DNeasy Plant Mini Kit (Qiagen, Germany) használatával. A DNS minőségét 1\%-os agaróz gélen ellenőriztük. A DNS-oldat koncentrációját és tisztaságát Nanodrop ND-1000 spektrofotométerrel (Bio-Science Kft, Budapest) határoztuk meg. A PCR reakcióhoz használt DNS mintákat, amennyiben szükséges volt, 20 ng/ $\mu 1$ koncentrációra hígítottuk.

\subsubsection{PCR-technika az NBS szekvenciák meghatározására}

Az NCBI adatbankban 9 növényfajból izolált NBS-LRR típusú rezisztenciagének szekvenciái közül kiválasztottunk 26 szekvenciát, melyek közül 8 a TIR-NBS-LRR, 18 pedig a CC-NBS-LRR típusú RGA családba tartozik. A felhasznált szekvenciák között 11 lúdfü, 4 paradicsom, 3 rizs, 2 burgonya, 2 len, 1 sárgadinnye, 1 napraforgó, 1 paprika és 1 dohány szekvencia szerepelt. A nukleotid- és aminosav-szekvenciákat a ClustalW program (Thompson és mts., 1994) alkalmazásával illesztettük. Az illesztett szekvenciákra manuálisan terveztük meg a degenerált primereket. A degenerált nukleotidok jelölését GCG szabvány szerint végeztük. A tervezett primerek permutációs indexének maximuma 10 000-szeres volt. A primerek szekvenciáját a 8. táblázat mutatja be.

Használtuk továbbá a Soriano és mts. (2005) által is alkalmazott, Gentzbittel és mts. (1998) által a P-loop [GxGxxGR(T/S)] motívumra tervezett P-loopGent F, illetve a Kanazin és mts. (1996) által a HD (GLPLxL) motívumra tervezett LM637 R primereket. A primereket a gödöllői Biomi Kft. ABI 3400 készülékkel (Applied Biosystem) szintetizálta.

Az amplifikációhoz a körülményeket gradiens PCR technikával optimalizáltuk az alábbi program szerint: kezdeti denaturálás $94{ }^{\circ} \mathrm{C} 2$ min, majd 35 cikluson keresztül: $94{ }^{\circ} \mathrm{C}$ $30 \mathrm{sec}, 48-60{ }^{\circ} \mathrm{C}$ (oszloponként növekvő) $45 \mathrm{sec}, 72{ }^{\circ} \mathrm{C} 1 \mathrm{~min}$, végül $72{ }^{\circ} \mathrm{C} 5 \mathrm{~min}$.

A PCR-hez 20-30 ng genomi DNS-t használtunk $25 \mu$ l végtérfogathoz. Az 1×PCR puffer (Promega) végső koncentrációja $10 \mathrm{mM}$ Tris- $\mathrm{HCl}(\mathrm{pH} 8,3), 50 \mathrm{mM} \mathrm{KCl}$ és 1,5 mM $\mathrm{MgCl}_{2}, 0,2 \mathrm{mM}$ dNTP, 0,4 $\mu \mathrm{M}$ az adott primerekből és 0,625 U GoTaq DNS-polimeráz (Promega). A továbbiakban a P-loop F és HD R primerek kötődési hőmérséklete $48^{\circ} \mathrm{C}$, $\mathrm{a}$ P-loopGent F és LM637 R primerereké pedig $54{ }^{\circ} \mathrm{C}$ volt. Az amplifikáció PTC 200 (MJ Research) típusú PCR gépben történt. 
8. táblázat. Az NBS-LRR típusú rezisztenciagénekre tervezett degenerált primerek szekvenciái és permutációs indexei

\begin{tabular}{|c|c|c|c|}
\hline Primer & Szekvencia 5'-3' & $\begin{array}{c}\text { Permutációs } \\
\text { index }\end{array}$ & Forrás \\
\hline CUB P-loop F & 5'-RTT GNA TGG GNG GNN TDGG-3' & 1536 & saját tervezés \\
\hline CUB Kin2 F & 5'-TND TNH TNG ATG AYR TNT GG-3' & 9216 & saját tervezés \\
\hline CUB HD R & 5'-GCY ARW GGY AVH CCW YYA CA-3' & 1152 & saját tervezés \\
\hline P-loopGent F & 5'-GAA TGG GKG GAG TYG GYA ARA C-3' & 16 & $\begin{array}{c}\text { Gentzbittel és } \\
\text { mts. (1998) }\end{array}$ \\
\hline LM637 R & 5'-ARI GCT ARI GGI ARI CC-3' & 2048 & $\begin{array}{c}\text { Kanazin és } \\
\text { mts. (1996) }\end{array}$ \\
\hline
\end{tabular}

$\mathrm{M}=\mathrm{A}+\mathrm{C}, \mathrm{S}=\mathrm{C}+\mathrm{G}, \mathrm{Y}=\mathrm{C}+\mathrm{T}, \mathrm{R}=\mathrm{A}+\mathrm{G}, \mathrm{W}=\mathrm{A}+\mathrm{T}, \mathrm{N}=\mathrm{A},+\mathrm{T}+\mathrm{G}+\mathrm{C}$,

$1 \%$-os TBE agaróz gélen [1x TBE (12,11 g Tris; 5,135 g bórsav; 0,372 g EDTA $1000 \mathrm{ml}$ desztillált vízben), 1 \% agaróz] megfuttattuk az így kapott mintákat, melyeket etídium-bromidos festéssel UV fény alatt tettünk láthatóvá. A kívánt hosszúságú fragmentumokat az 1\%-os agaróz gélből kivágtuk. A minták gélből való kitisztítása QIAquick Gel Extraction Kit (Qiagen, Germany) segítségével történt.

\subsubsection{SSCP (Single Strand Conformation Polymorphism)}

A pozitív klónokból származó PCR terméket egyszálú konformáció polimorfizmussal vizsgáltuk. A PCR termékből $8 \mu$ l-t, és a denaturáló stop festékből (FDE) (98\% deionizált formamid, $2 \%$ 0,5 M-os EDTA, 0,2\% brómfenolkék, 0,2\% xylene cianol kék) $7 \mu \mathrm{l}$-t mértünk össze és 5 percig $95{ }^{\circ} \mathrm{C}$-on denaturáltuk. Natív $10 \%$-os 0,8 mm vastag poliakrilamid gélen (19:1 akrilmid: bis -akrilamid v/v) $4{ }^{\circ} \mathrm{C}$-on 24 , illetve 48 órát futtattuk, 180 V feszültségen. A gélek ezüstfestését Schumacher és Randles (1983) leírása alapján végeztük.

\subsubsection{A PCR-termékek klónozása és DNS-szekvenciájuk meghatározása}

A gélből izolált PCR termékeket a pGEM-T Easy plazmid vektorba (Promega, USA) klónoztuk a gyártó útmutatásai szerint. A klónozott fragmentumokkal JM109 kompetens sejteket transzformáltunk. A teljes ligációs elegyet $80 \mu 1-70{ }^{\circ} \mathrm{C}$-on tárolt 
kompetens baktériumszuszpenzióval finoman összeráztuk, majd 20 percen át jégen tartottuk, azután 45 másodpercre $42{ }^{\circ} \mathrm{C}$-os vízfürdőbe helyeztük, majd azonnal jégre tettük 2 percig. Végül $950 \mu 137^{\circ} \mathrm{C}$-os folyékony, antibiotikum mentes LB táptalajt adtunk hozzá (10 g/l Bacto-tripton, $5 \mathrm{~g} / 1$ Bacto-élesztőkivonat, $10 \mathrm{~g} / 1 \mathrm{NaCl}, \mathrm{pH}=7)$, és másfél óráig rázattuk $37^{\circ} \mathrm{C}$-on, $150 \mathrm{rpm}$ fordulatszámmal. Ezután 100-400 $\mu 1$-nyi szuszpenziót szélesztettünk LB /ampicillin/IPTG/X-gal szilárd táptalajon: $10 \mathrm{~g} / 1$ Bacto-tripton, $5 \mathrm{~g} / 1$ Bacto-élesztőkivonat, $10 \mathrm{~g} / \mathrm{l} \mathrm{NaCl}, 7 \mathrm{~g} / \mathrm{l}$ agar, $100 \mu \mathrm{g} / \mathrm{ml}$ ampicillin $\mathrm{pH}=7$; a plate felszínén $100 \mathrm{mM}$ IPTG-t és $50 \mathrm{mg} / \mathrm{ml} \mathrm{X}$-galt oszlattunk szét, fél óráig $37^{\circ} \mathrm{C}$-on tartottuk a szélesztés előtt. A kész plate-eket fordított helyzetben $37^{\circ} \mathrm{C}$-on inkubáltuk egy éjszakán keresztül. A baktérium kolóniák színéböl következtetni tudtunk a ligálás sikerességére. A kék színű, negatív klónok nem tartalmazták az inszertet. A fehér, pozitív klónokat kolóniaPCR-rel ellenőriztük, hogy valóban tartalmazzák-e az általunk várt 500 bp körüli inszertet, a plazmidra tervezett M13 R és F primer kombinációval. Minden jól elkülöníthető, fehér színű telepet előbb átoltottunk steril fogpiszkáló segítségével egy masterplate-re, majd ugyanezt a fogpiszkálót helyeztük a kolónia PCR mixbe. A masterplate-en a telepeket egy éjszakán át $37^{\circ} \mathrm{C}$-on szaporítottuk fel. A megfelelő méretű inszertet tartalmazó klónokat tovább szelektáltuk egy semi-nested polimeráz láncreakcióval, amelyben a $\mathrm{HD} \mathrm{R}$ vagy LM637 R mellett a Kin2 F CC-NBS-LRR specifikus primert használtuk a következő programban: denaturáció $94{ }^{\circ} \mathrm{C}$-on $2 \mathrm{~min}$, majd 30 cikluson keresztül $94{ }^{\circ} \mathrm{C} 30 \mathrm{sec}, 56{ }^{\circ} \mathrm{C}$ $45 \mathrm{sec}$ és $72{ }^{\circ} \mathrm{C} 1 \mathrm{~min}$, végül $72{ }^{\circ} \mathrm{C}$ további $1 \mathrm{~min}$. A $25 \mu$ l végtérfogathoz itt is ugyanazokat az arányokat használtuk. Az $1 \times \mathrm{PCR}$ puffer (Promega, USA) végső koncentrációja $10 \mathrm{mM}$ Tris- $\mathrm{HCl}(\mathrm{pH} 8,3), 50 \mathrm{mM} \mathrm{KCl}$ és $1,5 \mathrm{mM} \mathrm{MgCl}_{2}, 0,2 \mathrm{mM} \mathrm{dNTP}$, 0,4 $\mu \mathrm{M}$ az adott primerekből és 0,625 U Taq DNS-polimeráz (Promega, USA).

A pozitív minták plazmid DNS-ének izolálását EZ-10 Spin Column Plasmid DNA Miniprep Kit (Biocenter Kft., Szeged), végeztük. Szekvenciájuk meghatározása ABI PRISM 3100 Genetic Analyzer (Applied Biosystem) automata DNS-szekvenátorral történt a Biomi Kft. gödöllői laboratóriumában.

\subsubsection{RNS-alapú kísérletek}

\subsubsection{Génexpressziós kisérletekhez történt mintagyüjtés}

A mintákat a Budapesti Corvinus Egyetem Genetika és Növénynemesítés Tanszék szigetcsépi ültetvényében szedtük a 'Zard' fajtáról két alkalommal: kettő illetve négy héttel a teljes virágzást követően, míg az 'Orange Red' fajtáról két héttel a teljes virágzást 
követően gyüjtöttük az ép és fertőzött mintákat. A nem fertőződött valamint a természetes virágfertőzést mutató vesszőket levágtuk és a gyors csomagolást és feliratozást követően szárazjégben illetve folyékony nitrogénben szállítottuk be a tanszéki laboratóriumba, ahol a feldolgozásig $-80{ }^{\circ} \mathrm{C}$-on tároltuk.

\subsubsection{RNS-izolálás és egyszálú cDNS szintézis}

A begyüjtött vesszőkből a fertőzés alatti ép háncsszövetről lelángolt szikével körben $1 \mathrm{~cm}$-es szakaszt hámoztunk le, majd steril dörzsmozsárban folyékony nitrogénnel porrá morzsoltuk. Az ép vesszőkből hasonlóan vettünk mintát. A ribonukleinsav-kivonást forró bórsavas extrakciós módszerrel végeztem Wan és Wilkins (1994) leírása alapján. A minták tisztaságát és mennyiségét Nanodrop ND-1000 spektrofotométerrel (Bio-Science Kft, Budapest) és minőségét $1 \%$-os TBE agaróz gélen ellenőriztük.

A cDNS szintézisét a First Strand cDNA Synthesis Kit (Fermentas Life Sciences, Biocenter Kft, Szeged) felhasználásával végeztük 5' végén biotin jelölt oligo dT (18 bp) indítószekvencia alkalmazásával a gyártó utasításai szerint.

\subsubsection{Kétszálú cDNS szintézis}

Az egyszálú cDNS-t kiegészítő második szál szintézisét DNS-polimeráz I és RN-áz H enzimek alkalmazásával végeztük az alábbiak szerint mintánként: 10x DNS-polimeráz I. puffer $10 \mu$ l, RNáz H (E. coli, $5 \mathrm{U} / \mu \mathrm{l}$ ) 0,2 $\mu$ l, DNS-polimeráz I. (E. coli, $10 \mathrm{U} / \mu \mathrm{l}) 2,2 \mu \mathrm{l}$, MQ-víz (ioncserélő gyantán (Milli-Q) megszürt desztillált víz) 67,6 $\mu$ l, egyszálú cDNS $20 \mu 1$. A mintákat $15{ }^{\circ} \mathrm{C}$-on két órán keresztül inkubáltuk. A protokolltól eltérve nem alkalmaztuk a második szál egységeinek összekapcsolásához ajánlott E.coli ligázt.

A ds cDNS végterméket kitisztítottuk. A $100 \mu 1$ ds cDNS termékhez $200 \mu 1$ MQvizet adtunk, majd $300 \mu \mathrm{l}$ fenol:kloroform:izoamil-alkohol (25:24:1 v/v) keverékével extraháltuk. Ezt követően a mintákat $12000 \mathrm{rpm}$ fordulatszámon, $4{ }^{\circ} \mathrm{C}$-on 15 percig centrifugáltuk. A felső vizes fázist tiszta csövekbe vittük át. A mintákat $300 \mu 1$ kloroform:izoamil-alkohol $(24: 1 \mathrm{v} / \mathrm{v})$ keverékével extraháltuk, majd 5 percig újra centrifugáltuk. A vizes fázist tiszta csőbe pipettáztuk át, majd hozzáadtunk $30 \mu 14 \mathrm{M}$-os nátrium-acetátot, és $2,5 \mathrm{x}$-es térfogatú $-20^{\circ} \mathrm{C}$-os, $96 \%$-os etanollal $(750 \mu 1)$ kicsaptuk és 1 óráig -20 ${ }^{\circ} \mathrm{C}$-on inkubáltuk. Ezt követően $13000 \mathrm{rpm}$-en, $4{ }^{\circ} \mathrm{C}$-on centrifugáltuk, majd a felülúszót eltávolítottuk. A mintákat $500 \mu 170 \%$-os, $-20{ }^{\circ} \mathrm{C}$ etanollal kétszer mostuk, majd végül a mintákat vákuumcentrifugában leszárítottuk. A kétszálú cDNS-t $30 \mu 1 \mathrm{MQ}$ vízzel 
oldottuk vissza. A minták tisztaságát és koncentrációját NanoDrop 1000 típusú spektrofotométerrel (Bio-Science Kft, Budapest) ellenőriztük.

\subsubsection{4 cDNS AFLP}

A cDNS AFLP technikát Vuylsteke és mts. (2007) leírása alapján végeztük, kisebb módosításokat alkalmazva. A technika lépéseit a 6. mutatja be. Az első emésztés előtt a mintáinkat $25 \mathrm{ng} / \mu \mathrm{l}$ koncentrációra hígítottuk. Az első restrikciós emésztést a EcoRI enzimmel végeztük az alábbi mintánkénti összetétellel: MQ-víz $15 \mu 1,10 x$ Reakció puffer

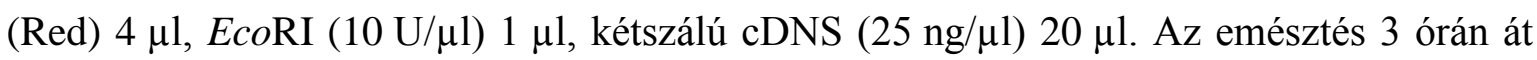
$37{ }^{\circ} \mathrm{C}$-on történt.

A biotin-jelölt részek kinyerését Dynabeads ${ }^{\circledR}$ M-280 Streptavidin (Invitrogen) gyöngyökkel végezetük. Mintánként $10 \mu 1$ Dynabeads oldatot szuszpendáltunk fel $100 \mu 1$ 2xSTEX (40 ml NaCl (5 M), $2 \mathrm{ml} 1 \mathrm{M}$ Tris-HCl (pH 8.0), $400 \mu 10.5 \mathrm{M}$ EDTA, $2 \mathrm{ml}$ TritonX-100 100 ml-re MQ vízzel kiegészítve) oldatban. Mágneses cső állványban összegyüjtöttük a vas gyöngyöket és leszívtuk az oldatot. A második aktiváló mosás $40 \mu 1$ 2xSTEX pufferben történt. Az első emésztésen átesett mintákat (40 $\mu 1)$ a már felületaktív Dynabeads gyöngy szuszpenzióval (40 $\mu 1)$ kevertük össze.

Ezután a mintákat a mágneses állványba helyeztük, a felülúszót óvatosan leszívtuk, majd a kitapadt vasionos részt $100 \mu \mathrm{l}$ 1xSTEX-sel mostuk, új csőbe pipettáztuk tovább. Ezt a lépést négyszer ismételtük. Az utolsó mosásnál a mágnessel összegyüjtöttük a gyöngyöket, a felülúszót eltávolítottuk, majd $30 \mu \mathrm{l} \mathrm{T}_{10} \mathrm{E}_{0.1}$ pufferrel $(1 \mathrm{ml} 1 \mathrm{M}$ Tris- $\mathrm{HCl}$ pH 8.0, $20 \mathrm{ml} 0.5$ M EDTA $100 \mathrm{ml}$ végtérfogatra kiegészítve MQ-vízzel) a gyöngyöket felszuszpendáltuk és új csőbe pipettáztuk át.

A második restrikciós endonukleázos emésztésnél a TruI enzimet választottuk, ami az MseI restrikciós endonukleáz izoskizomerje. A mintákhoz (30 $\mu 1)$ a következő összetevőket adtuk: MQ-víz $5 \mu 1,10 x$ puffer R $4 \mu 1$, TruI. (10 U/ $\mu 1) 1 \mu 1$. Az emésztés $65^{\circ} \mathrm{C}$-on 2 órán át tartott PTC 200 (MJ Research) típusú PCR készülékben. Az emésztést követően mágnessel a gyöngyöket összegyüjtöttük, és a felülúszót (40 $\mu 1)$ új csőbe pipettáztuk át. 
Elsō szál cDNS szintéżs biotin jelött oligodT primerrel

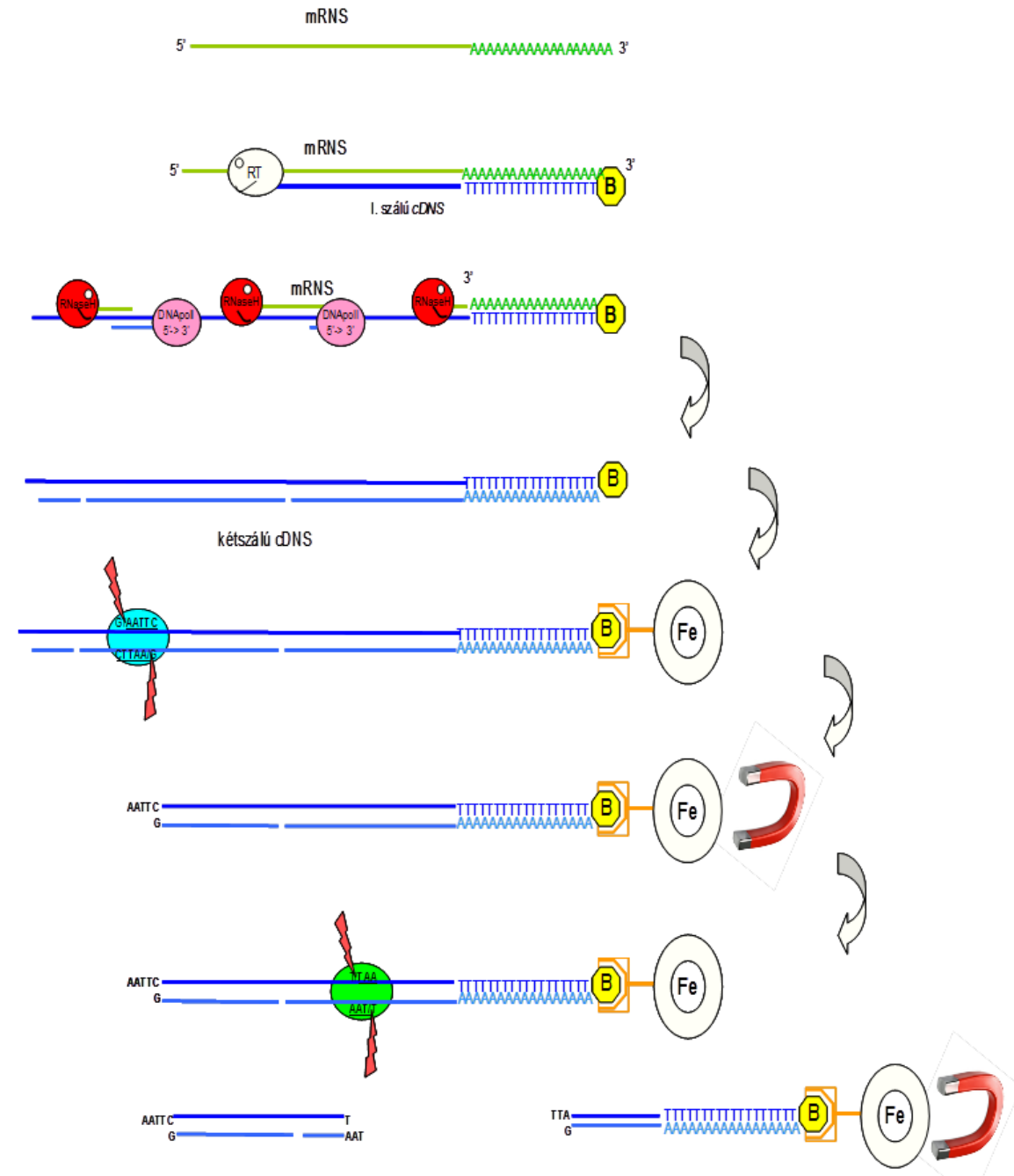

Hés DNS polimeráz l.

használatával

I. A biotin jelölt poli A szekvenciat tartalazó részek eltávolitása

6. ábra. A cDNS AFLP 'One gene-one tag’ (Vuylsteke és mts., 2007) sematikus ábrája.

A második emésztést követő szelekciós lépéssel kizárólag a két végén eltérő ragadós végekkel rendelkező DNS szakaszok alakultak ki a két eltérő emésztés hatására (TruI 5'-TA-3' és EcoRI 5'-AATT-3'). A végső mintaszál a ragadós végekhez történö adapterek ligálásával készült el (9. táblázat). A ligációs reakcióelegy a következő összetevőket tartalmazta mintánként: MQ-víz 5,34 $\mu 1,10 x$ reakciós puffer $1 \mu 1$, T4 DNS-

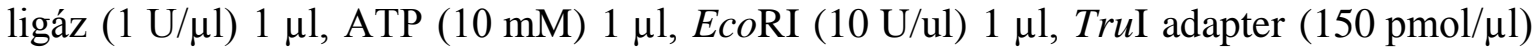
$0,33 \mu 1, E c o R I$ adapter ( $15 \mathrm{pmol} / \mu \mathrm{l}) 0,33 \mu \mathrm{l}$. 
A ligációs mix hozzáadása után a mintákat 3 óráig, $37^{\circ} \mathrm{C}$-on inkubáltuk, ezután pedig $50 \mu 1 \mathrm{~T}_{10} \mathrm{E}_{0.1}$ puffert adtunk hozzá. Ezzel az eljárással mintánként $100 \mu 1$ templátot kaptunk.

9. táblázat. Az adapterek szekvenciái

\begin{tabular}{|l|l|}
\hline EcoRI adapter & \multicolumn{2}{|c|}{5 CTCGTAGACTGCGTACC } \\
& $3, \quad$ CTGACGCATGGTTAA \\
\hline TruI adapter & 5 GACGATGAGTCCTGAG \\
& $3, \quad$ TACTCAGGACTCAT \\
\hline
\end{tabular}

A cDNS AFLP első polimeráz láncreakciója (preamplifikáció) szelektív nukleotidot nem tartalmazó indítószekvenciákkal (10. táblázat) készült az alábbi összetétellel: MQ-víz 30,5 $\mu 1,10 \mathrm{x}$ puffer $5 \mu \mathrm{l}, \mathrm{MgCl}_{2}(20 \mathrm{mM}) 5 \mu \mathrm{l}$, dNTP mix $(10 \mathrm{mM}) 1 \mu 1, E c o \mathrm{RI}+0$ primer (50 ng/ $\mu \mathrm{l})$ 1,5 $\mu \mathrm{l}$, TruI+0 primer $(50 \mathrm{ng} / \mu \mathrm{l})$ 1,5 $\mu \mathrm{l}$, DreamTaq $(5 \mathrm{U} / \mu \mathrm{l})$ 0,5 $\mu \mathrm{l}$. A PCR elegyhez $5 \mu 1$ templátot adtunk és a következő programot állítottuk be a PTC 200 típusú (MJ Research) PCR készüléken: 94 C 3 min, 25 cikluson keresztül $94{ }^{\circ} \mathrm{C} 30 \mathrm{~s}, 56{ }^{\circ} \mathrm{C} 1 \mathrm{~min}$ és $72^{\circ} \mathrm{C} 1 \mathrm{~min}$, végül $72^{\circ} \mathrm{C} 5 \mathrm{~min}$. A mintákból $5 \mu 1$-t $1 \%$ TBE agaróz gélen választottunk el, és etidium bromidos festéssel tettük láthatóvá. A mintákat 600-szorosra hígítottuk $\mathrm{T}_{10} \mathrm{E}_{0.1}$ pufferrel.

A cDNS AFLP második polimeráz láncreakciójánál 3 szelektív nukleotidot tartalmazó indítószekvenciákat alkalmaztunk a

11. táblázatban bemutatott kombinációk szerint az alábbi összetétellel: $M Q$ víz 9,65 $\mu 1,10 x$ DreamTaq puffer $2 \mu 1, E c o \mathrm{RI}+3$ primer $(1 \mathrm{pmol} / \mu \mathrm{l}) 0,05 \mu \mathrm{l}, \mathrm{Mse}+3(10 \mathrm{ng} / \mu \mathrm{l})$ $0,3 \mu 1$, DreamTaq polimeráz $(5 \mathrm{U} / \mu \mathrm{l}) 0,3 \mu \mathrm{l}, \mathrm{MgCl}_{2}(20 \mathrm{mM}) 2 \mu \mathrm{l}$, dNTP mix $(10 \mathrm{mM})$ 0,4 $\mu 1$. A 600 -szorosra hígított prePCR termékekből $5 \mu 1$-t használtunk templátként a reakciókban. Az alkalmazott PCR program: $94{ }^{\circ} \mathrm{C} 3 \mathrm{~min}, 13$ cikluson keresztül $94{ }^{\circ} \mathrm{C} 30 \mathrm{~s}$, $65^{\circ} \mathrm{C} 30$ s ciklusonként $0,7^{\circ} \mathrm{C}$-al csökkentve és $72^{\circ} \mathrm{C} 1 \mathrm{~min}$, a 14 . ciklustól további 22 cikluson keresztül $94^{\circ} \mathrm{C} 30 \mathrm{~s}, 56^{\circ} \mathrm{C} 30 \mathrm{~s}$ és $72^{\circ} \mathrm{C} 1 \mathrm{~min}$, végül $72^{\circ} \mathrm{C} 5 \mathrm{~min}$. A reakció sikerességét a poliakrilamid gélelektroforézis előtt $1 \%$-os TBE agaróz gélen ellenőriztük. 
10. táblázat. A cDNS AFLP reakció során alkalmazott primerek, piros színnel vannak jelölve a restrikciós emésztés eredményéül kialakult ragadós végek, míg kékkel a szelektív nukleotidok.

\begin{tabular}{|l|l|}
\hline Primer neve & Szekvencia 5'-3' \\
\hline Mse I + 0 & 5'-GATGAGTCCTGAGTAA \\
\hline EcoRI + 0 & 5'-GACTGCGTACCAATTC \\
\hline$M s e \mathrm{I}+\mathrm{CTT}$ & 5'-GATGAGTCCTGAGTAA CTT \\
\hline$M s e \mathrm{I}+\mathrm{CAG}$ & 5'- GATGAGTCCTGAGTAA CAG \\
\hline EcoRI + ACC & 5'-GACTGCGTACCAATTC ACC \\
\hline
\end{tabular}

11. táblázat. Az alkalmazott primer kombinációk

\begin{tabular}{|l|l|}
\hline Primer kombináció száma & \\
\hline I. & $E c o$ RI + ACC és Mse I. + CTT \\
\hline II. & $E c o$ RI + ACC és MseI. + CAG \\
\hline III. & $E c o R I+0$ és MseI + CTT \\
\hline IV. & $E c o$ RI + 0 és $M s e I+C A G$ \\
\hline
\end{tabular}

\subsubsection{Poliakrilamid gélelektroforézis (PAGE)}

A mintákat $8 \%$-os denaturáló akrilamid gélen választottuk el Sequi-Gen (BioRad, Budapest) vertikális elektroforézis készülékkel. Az üveglapok akrilamiddal érintkező oldalát elsőként $97 \%$-os alkohollal megtisztítottuk. Az futtatókészülékkel összeépített üveglapot (hosszú) $500 \mu 1$ Repel Silane (Promega, USA) oldattal kezeltük, ez biztosítja a gél és az üveglap elválását. A gél tapadását a másik (rövid) üveglaphoz Bind Silane (Promega, USA) kezeléssel (5 $\mu 1$ Bind Silane, $5 \mu 196 \%$-os ecetsav, $5 \mathrm{ml} 95 \%$-os etilalkohol) biztosítottuk. A keveréket egyenletesen eloszlattuk az üvegfelületen, majd az elpárolgást követően a kezelt lapot áttöröltük $95 \%$-os etanollal, ezután 5 percig száradni hagytuk. A készüléket ezután raktuk össze. Az üvegfelületek kezelését elszívófülke alatt végeztük. A $100 \mathrm{ml}, 8 \%$-os gél a következöképpen készült: $20 \mathrm{ml} 40 \%$-os akrilamidhoz (19:1 akrilamid: bis-akrilamid v/v) hozzáadtunk 45 g ureát (Reanal, Budapest) (10x), majd $10 \mathrm{ml}$ 10xTBE-t. Ezt 100 ml-re egészítettük ki desztillált vízzel. Miután az urea teljesen feloldódott $\quad 0,1 \mathrm{~g}$ ammónium-peroxi-diszulfátot (APS) (Reanal, Budapest) $1000 \mu \mathrm{l}$ 
desztillált vízben feloldottunk csőben. Ebből $500 \mu$ l-t tettünk bele az akrilamid oldatba. Közvetlenül a két üveglap közé juttatás előtt az oldathoz hozzáadtunk $100 \mu 1$ tetrametiletilén-diamint (TEMED) (Sigma-Aldrich, USA), hogy a polimerizációt beindítsuk. A polimerizáció 30 perc alatt ment végbe, a gélt $38^{\circ} \mathrm{C}$-ra melegítettük elő $80 \mathrm{~W}$-on. Ezt követően $6 \mu \mathrm{l}$ PCR tereméket, $2 \mu \mathrm{l}$ FDE festékkel (10 ml deionizált formamid, $200 \mu 10.5$ M EDTA (pH 8,0), $10 \mathrm{mg}$ xylene cyanol) elkevertünk és $92^{\circ} \mathrm{C}$-on 5 percig denaturáltuk PCR készülékben, majd a mintákat a gélre történő felvitelig jégen tartottuk. A minták elválasztása állandó teljesítmény mellett $80 \mathrm{~W}$-on 5 órán át történt. A denaturáló akrilamid gél ezüstfestését Bassam és Gresshoff (2007) leírása alapján végeztük, amit a vizuális értékelésük követett.

A gélből a visszaizolálandó fragmentumokra $50 \mu 1$ MQ vizet pipettáztunk és lelángolt szikével a gél darabot kivágtuk, majd gélt lefényképeztük. A kivágott darabokat $100 \mu \mathrm{l} \mathrm{T}_{10} \mathrm{E}_{0.1}$ pufferben $4{ }^{\circ} \mathrm{C}$-on tartottuk egy órán át, majd a felülúszót új csőbe pipettáztuk.

A gélből kitisztított fragmentumok felszaporításához (reamplifikáció) polimeráz láncreakciót végeztünk az eredeti reakció indítószekvenciáival az alábbi összetevőket alkalmazva mintánként: MQ-víz $10 \mu 1,10 x D r e a m T a q$ puffer $2 \mu 1$, EcoRI+3 primer

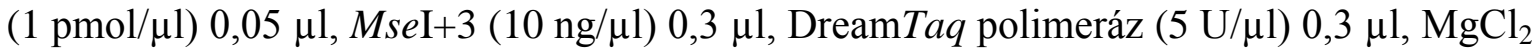
(20 mM) $2 \mu$, dNTP mix $(10 \mathrm{mM}) 0,4 \mu 1$, templát DNS $5 \mu$ l. A reakció során az AFLP második polimeráz láncreakciójának programját használtuk.

A PCR termékeket $1 \%$-os TBE agaróz gélen ellenőriztük és azoknál a mintákat, ahol egy határozott csíkot kaptunk szekvenálásra kitisztítottuk. A tisztításhoz $5 \mu 1$ mintához 0,5 $\mu \mathrm{l}$ (10 U) Exonuclease I-et (Fermentas, Biocenter, Szeged), és $1 \mu \mathrm{l}$ (1 U) FastAp Thermosensitive Alkaline Phosphatase-t (Fermentas, Biocenter, Szeged) adtunk. Ezután PCR készülékben $37{ }^{\circ} \mathrm{C}$-on 15 percig inkubáltuk. A reakciót $85{ }^{\circ} \mathrm{C}$-os, 15 perces inkubálással zártuk le. Ezután a mintákat az eredeti primereket alkalmazva ABI PRISM 3100 Genetic Analyzer (Applied Biosystems) készülékkel a szegedi Baygen Sequencing Platform szolgáltató cégnél szekvenáltattuk meg. 


\subsubsection{PGIP gén szekvenciájára tervezett primerek}

Az alma és az őszibarack PGIP gén szekvenciáival homológiát $\left(E\right.$-érték $\left.<10^{-50}\right)$ mutató Prunus szekvenciákat a NCBI BLASTn és BLASTp programját (Altschul és mts., 1990) alkalmazva gyüjtöttük ki.

A ClustalW (Thompson és mts., 1994) program segítségével a szekvenciákat illesztettük. A konzervált részekre négy primert terveztünk (12. táblázat)

12. táblázat. A Rosaceae fajokból származó PGIP gének illesztése alapján tervezett indítószekvenciák

\begin{tabular}{|c|c|c|}
\hline Primer & Szekvencia 5'-3' & Hossza (bp) \\
\hline PGIP CONS1 F & CATCCTAAACC(C/A)AGC(T/G)CTCTC & 20 \\
\hline PGIP CONS2 F & AGC(T/G)CTCTC(C/A/T)GAGCTCTGC & 19 \\
\hline PGIPZ R & GATCCAAGGAAGTCAAGCTCTTC & 23 \\
\hline PGIP R & AACTGTTGTAGCTCACGTTCAGGA & 24 \\
\hline
\end{tabular}

A lehetséges négy primerkombinációt alkalmazva (a korábban alkalmazott PCR reakció körülményeivel azonos módon) gradiens $\left(48-61{ }^{\circ} \mathrm{C}\right)$ PCR-t végeztünk. Három fajtagenomi DNS-én ('Zard', 'Orange red', 'Korai zamatos') és a 'Zard' és az 'Orange red' fajta első alkalommal gyüjtött fertőzött vesszőiről származó cDNS templátokon a PGIP R és PGIP CONS $1 \mathrm{~F}$ primerkombináció alkalmazásával készült PCR termékeket agaróz gélelektroforézis során választottuk szét. A PCR reakció körülményei a korábban alkalmazott feltételekkel megegyeztek $58^{\circ} \mathrm{C}$-os tapadási hőmérséklet alkalmazásával. A korábban leírt protokollokat követve 9 fragmentumot izoláltunk gélből, és ezeket klónoztuk. A genomi DNS-ről készült plazmidokból ötöt, míg a cDNS templátokról készült termékek közül 10-10 plazmidot küldtünk el szekvenciameghatározására.

\subsection{Bioinformatikai vizsgálatok}

\subsubsection{Az NBS RGA szekvenciák bioinformatikai vizsgálata}

A DNS szekvenciákat és ezek transzlált aminosav szekvenciáit BLASTn és BLASTp programok segítségével hasonlítottuk össze az NCBI (NCBI: http://www.ncbi.nlm.nih.gov) szekvencia adatbázisban található szekvenciákkal. Húsz nagy azonosságot ( $E$ érték $<1 \times 10^{-50}$ ) mutató RGA szekvenciát és 20 referenciának tartott eltérő fajokból származó R gén NBS szekvenciáját töltöttük le a szekvencia adatbázisból. 
A filogenetikai analízishez ezeket és a Samuelian és mts. (2008) által összegyüjtött 262 Rosaceae NBS szekvenciáját alkalmaztuk. A szekvenciák illesztését a Clustal W program segítségével végeztük (Thompson és mts. 1994). A filogenetikai törzsfát a Mega 5.0 szoftvercsomaggal (Tamura és mts. 2011) szerkesztettük meg a legközelebbi szomszédok csoportosítását alkalmazó módszerrel (neighbour joining method) előállított és Kimura 2 modellt alkalmazó algoritmussal. Az elágazások megbízhatóságát a törzsfán 1000-szeres bootstrap analízissel ellenőriztük.

\subsubsection{A cDNS AFLP szekvenciáinak bioinformatikai vizsgálata}

A kapott nukleinsavszekvenciák vizsgálatához az NCBI BLASTn és BLASTp programját (Altschul és mts., 1990) és a Phytozome v8.0 programot (Goodstein és mts.,

2012) használtuk. A szekvenciák funkciójának felderítésére homológia alapján a Phytozome v8.0 program által támogatott PFAM, KOG, KEGG, and PANTHER adatbázis kereső programokat alkalmaztuk. A 15. TDF (transzkriptumból származó fragmentum) szekvenciával homológ gént a Phytozome 8.0 szekvencia adatbázis (Goodstein és mts., 2012) segítségével az őszibarack és az alma genomján kerestük meg. A szekvenciák egymáshoz illesztéséhez a ClustalW programot használtuk, a filogenetikai törzsfa készítéséhez a MEGA 5.0 szoftercsomagot alkalmaztuk (Tamura és mts., 2011).

Az expressziós vizsgálatok eredményéül kapott szekvenciák homológiavizsgálatakor az $E$-érték $<10^{-8}$ hasonlóságot mutató találatokat fogadtuk el. 


\section{Eredmények}

\subsection{A kajszi ellenállóságának vizsgálata $M$. laxa fertőzésre}

\subsubsection{Az ellenállóság szabadföldi bonitálása}

A fajták fogékonyságának összehasonlításakor elsőként a fertőzött virágszámot rögzítettük, ami már a felvételezéskor nehézségekbe ütközött. Az azonos nóduszon található fertőzött virágokról nehezen lehetet eldönteni, hogy a fertőzés egy vagy több független virágfertőzésből származik-e. Ellentmondásos volt, hogy nem minden egyes virágfertőzés végződött feltétlen vesszőfertőzéssel, mert a fertőzött virágrészek a kórokozó vesszőbe hatolása előtt leválhatnak a termőrészről.

Másik nehézséget a kajszi alternanciája okozta, mert a gyümölcsritkítás hiányában néhány fajta nem fejlesztett virágrügyeket a túl kötöttség miatt. Emiatt 'Goldrich' fajta esetében a vizsgálat első két évében a termőrészpusztulás $30 \%$-ról $5 \%$-ra csökkent, amit a kihagyó évre jellemző virágrügyek hiánya okozott.

A fajtákra jellemző termőrész-képződése nagyon eltérő, így a hosszú termőrészeken (vesszők) termő fajták esetében egyetlen virág fertőzése az alapi részen teljes hosszban okozza a vessző hervadását, míg a rövid termőrészen (termőnyárs) a virág fertőzése kevesebb termés kieséssel és fás rész pusztulásával jár. A fajták termőrész fertőzöttségének mértéke határozza meg a fajták érzékenységét, illetve ellenállóképességét.

A moniliás termőrészpusztulás felvételezéskor figyelembe vettem a termés mennyiségét és az alternáló egyedeket kizártam a vizsgálatból. A bonitálás eredményét a 7. ábra mutatja be.

A fertőzésnek teljesen ellenálló diploid japánszilvafajták egyedein nem volt megfigyelhető a termőrész károsítása, habár a gyümölcsmúmiák mint elsődleges fertőzési források közelsége ellenére is csak sziromfertőzést figyeltünk meg (8. ábra).

A $P$. dasycarpa egyedein, az 1/33 cseresznyeszilva és kajszi interspecifikus hibriden sem figyeltünk meg a 3 év alatt moniliás vesszőfertőzést. Az ültetvényben található cseresznyeszilva alany fán, a korona belső felében rövid termőrészek 1-2 \%-os pusztulását figyeltük meg. Így ezeket a fajokat és fajtákat teljesen immunisnak tekintjük. 


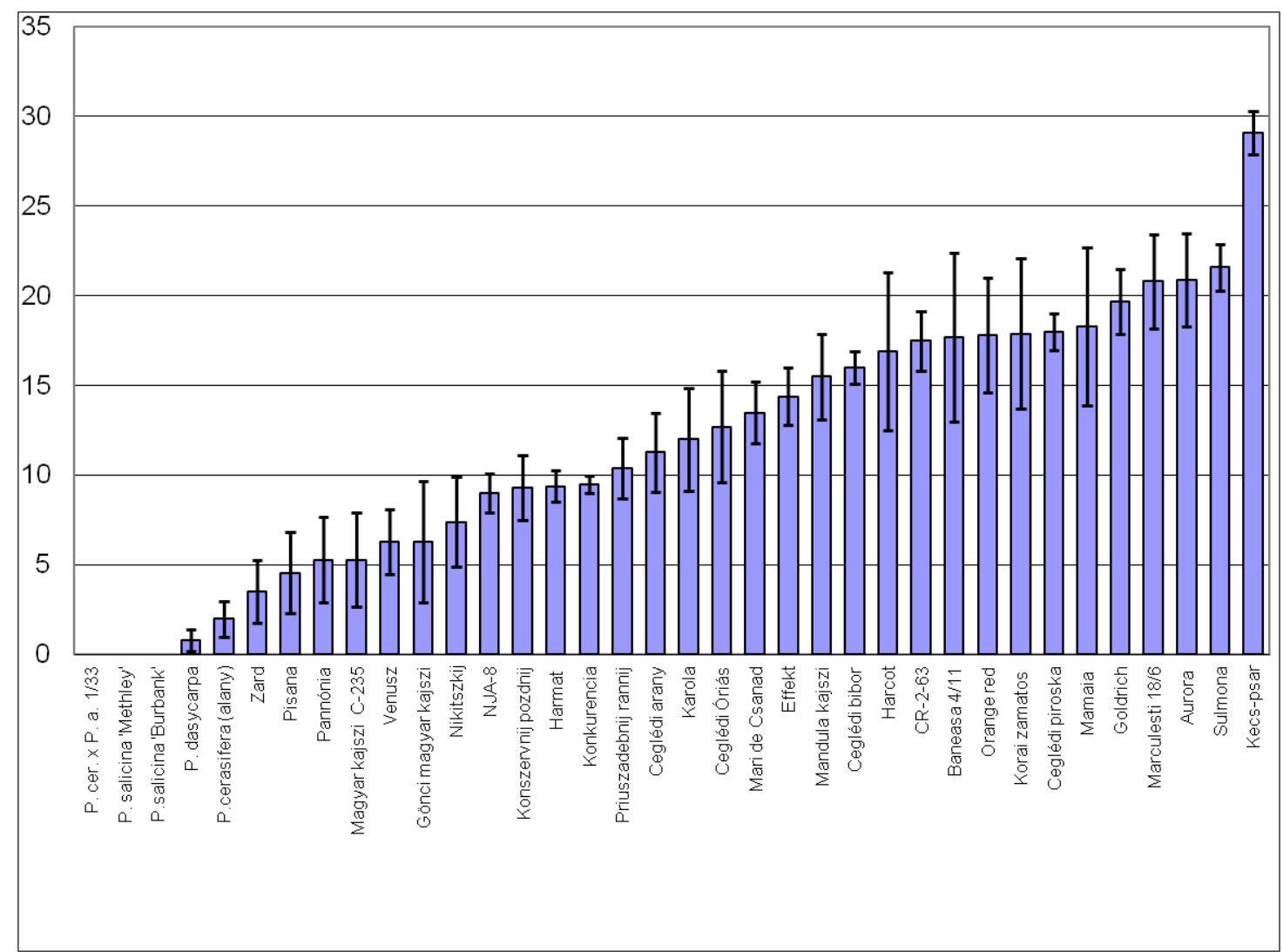

7. ábra. Érzékenységi sor a 2006-2009 között vizsgált kajszi és diploid szilva ( $P$. cerasifera, $P$. salicina) genotípusok $M$. laxa fertőzésére. A diagram a fertőzött termőrészek százalékos arányát mutatja be.

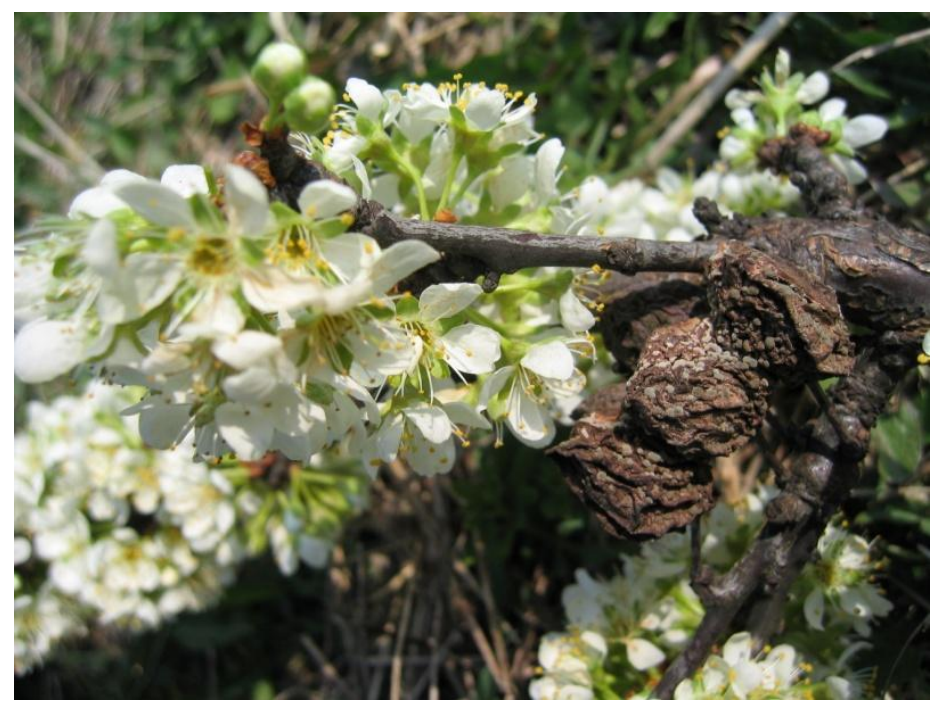

8. ábra. A $P$. salicina 'Methley' fajtán a fertőzési forrás gyümölcsmúmiák tömeges előfordulása ellenére sem tapasztaltunk termőrészpusztulást a vizsgálat három évében. 
A kajszifajták közül a közép-ázsiai ‘Zard’ fajta bizonyult a legellenállóbbnak (7. és 9. ábra). A 'Zard' esetében előfordult ugyan a virágfertőzés, de hosszú termőrész pusztulás egyetlen esetben sem történt a három év alatt. A virágfertőzést, a virágkocsány körül maximum 5 mm-es körben jelentkező a háncsszövet károsodás követte. A fa belsejében a rövid leárnyékolt gyenge növekedésű termőrészek esetében ez a fertőzés ritkán a termőrész pusztulásával járt.

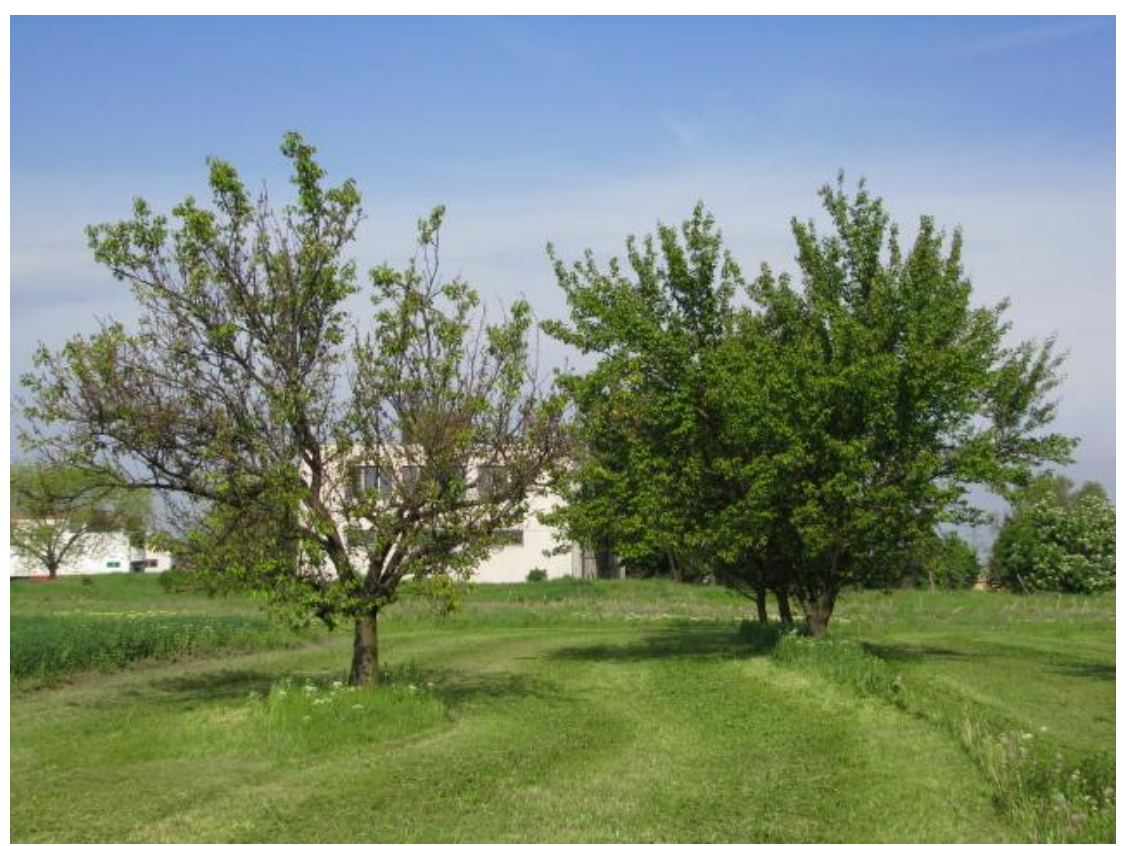

9. ábra. A Monilinia laxa kártétele két kajszifajtán. A baloldalon az 'Orange red' fajta $30 \%$ feletti termőrész pusztulása, míg a jobb oldalon az 1-2 \%-os rövid termőrész károsodást elszenvedő 'Zard' fajta látható. A felvétel 2010-ben a felhagyott szigetcsépi génbankban készült.

A következő fogékonysági kategóriába a 'Pisana', 'Pannónia', 'Vénusz', 'Magyarkajszi C235', 'Gönci magyarkajszi', 'Nyikitszkij' fajták sorolhatók. Ezeknél a fajtáknál nem érte el a fertőzés az összes termőrész $10 \%$-os fertőzöttségi mértéket. A magyarkajszi fajtakörhöz tartozó fajták esetében az ellenállóság nem volt egyértelműen meghatározható. Ezeknél a fajtáknál nem volt tapasztalható a 'Zard' fajtával hasonló módon müködő ellenállóság, a virágfertőzésen túl a hosszú termőrészek pusztulása is megfigyelhető volt. A magyarkajszi fajtakörre kis virágszám volt jellemző, amelyek elsősorban a rövid termőrészeken helyezkedtek el.

A $10 \%$-os termőrészfertőzés mértékét elérő fajták az NJA-8, 'Konszervnij pozdnij', 'Harmat', 'Konkurencia', 'Priuszedebnij rannij’, 'Ceglédi arany', 'Karola' fajták voltak. Az érzékenységi sorban a $15 \%$ körüli fertőzöttséget mutató fajták sorrendben a 
következők: 'Ceglédi óriás', 'Mari de Canad', 'Effekt', 'Mandulakajszi', 'Ceglédi bíbor'. A 15-20\% közötti termőrészpusztulást mutató fajták esetében volt megfigyelhető a legnagyobb szórás. Az érzékenységi sorban a legfogékonyabb fajtákon - 'Marculesti 18/6', 'Aurora', 'Sulmona', 'Kecs-psár' - 5 héttel a virágzást követően a termőrészek több mint $20 \%$-a pusztult el. A kiugró érzékenységgel rendelkező a 'Kecs-psár' fajtán $25 \%$-os termőrész pusztulás jelentkezett. Ezen a fajtán a megfigyeltük a pirosbimbós stádium előtti spontán fertőzés kialakulását, ami a virágzás alatti időjárástól függetlenül mindegyik évben kialakult (10. ábra).

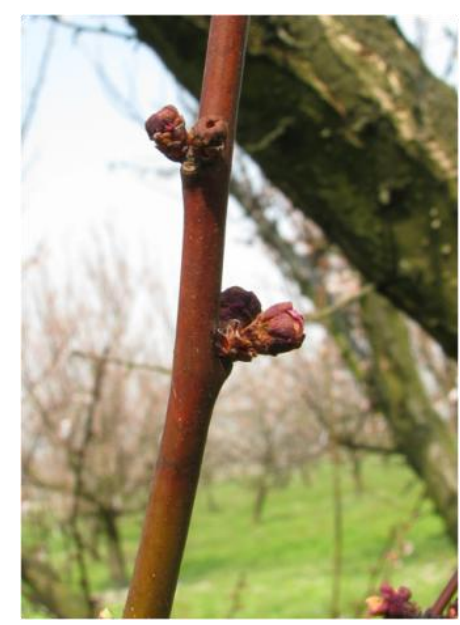

10. ábra. A 'Kecs-psár' fajta virágai és vesszője a bimbó felnyílása előtt már a fertőzés tüneteit mutatják. Ezeket a spontán fertőzött virágokat és termőrészeket eltávolítottuk a mesterséges virágfertőzési kísérlet beállítása előtt.

A $P$. sibirica és $P$. mume faj egyedeinek vizsgálatát a Vácrátóti Botanikus Kertben végeztük 2009-2011 között. A P. mume egyedein nem tapasztaltuk az M. laxa fertőzését. A négy vizsgált évben csak két alkalommal virágoztak a japánkajszi fák, mert a virágrügyek 2009-ben és 2010-ben teljes téli fagykárt szenvedtek. A szibériaikajszi estében mindegyik évben 30\%-os termőrész pusztulást figyeltünk meg, ami a 'Kecs-psár' fajta fogékonyságához volt hasonló. Mivel ezekböl a fajokból 2-2 egyeden történt a felmérés, és ezek magonceredetűek, így az eredményeket nem tüntettük fel a grafikonon.

\subsubsection{Virágrészek érzékenysége a kórokozóval szemben}

\subsubsection{A kasztrálás és megporzás hatása a virágfertözés kialakulására}

A 'Goldrich' fajta virágjainak természetes fertőzését megvizsgálva megfigyeltük, hogy a fertőzés a virágszirmon és porzószálakon jelenik meg elsőként (11. ábra 'A' kép). A fertőzött virágok leghosszabban épen maradó része a bibe volt (11. ábra ' $B$ ' kép). 


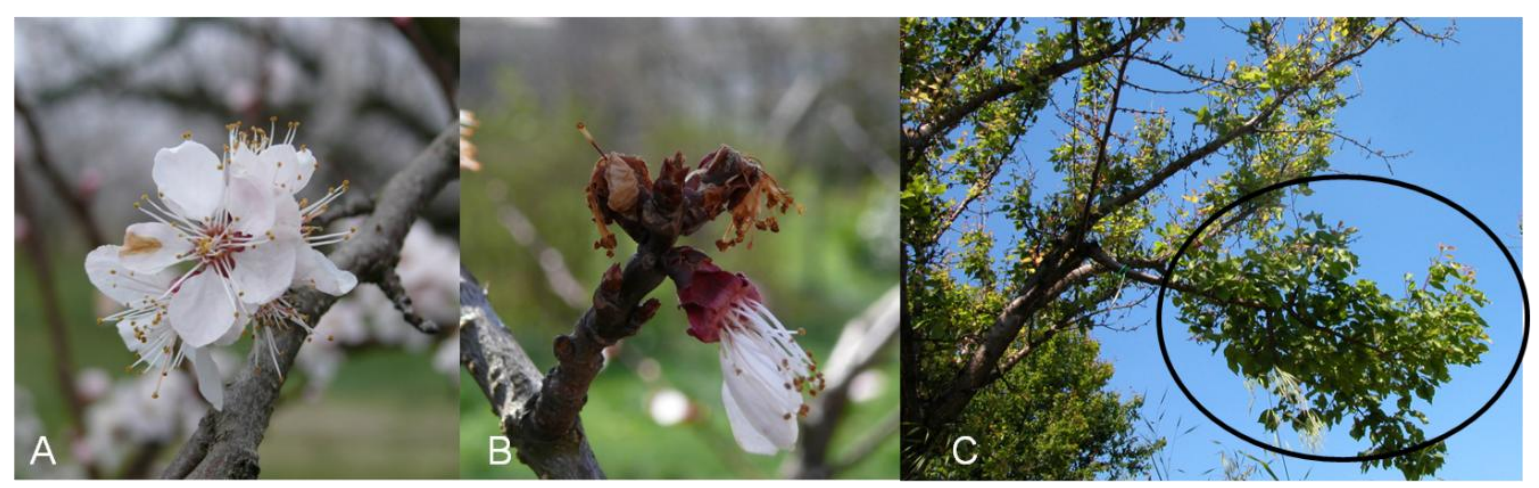

11. ábra. A: A Monilinia laxa fertőzés kezdete szirmon. B: 'Goldrich' termőnyársának moniliafertőzése. A bibe a legtovább ép szövettáj fertőzés során. C: A 'Kecs-psár' fajtán a keresztezett ágon (fekete karikával jelölve) nem figyelhető meg a többi ágrésszel szemben monilia fertőzés okozta termőrész pusztulás.

A virágfertőzés lefolyásának meghatározását a keresztezéskor megfigyelt jelenség segítette. A keresztezett ágakon elmaradt a fertőzés legfogékonyabb fajták esetében is (11. ábra 'C' kép). A keresztezéskor az összes virágot kasztráljuk a kijelölt ágon. A kasztrálás a porzók a szirmok és a vacoköböl mechanikai eltávolítását jelenti, amit a mesterséges megporzás követ. Annak eldöntésére, hogy a megporzás vagy a kasztrálás felelős a keresztezett ágakon a virágok 'ellenállóságáért' két fajtán végeztük el a kasztrálást megporzás nélkül és a kasztrálást megporzással. A két kezelés összehasonlítása a fertőzött virágszám alapján történt.

A 'Goldrich' fajta esetében a 111 kasztrált és megporzott virágból összesen egy esetében találtunk fertőződést, a kasztrált és megporozatlan 118 virág mindegyike ép volt. A pozitív kontrollnak szánt szabadelvirágzású ágakon 201 virágból 43 esetben tapasztaltuk a fertőzés tüneteit. 'Kecs-psár' fajta esetében a kasztrálás során is megfigyeltük még fel nem nyílt virágokon a spontán fertőzés tüneteit (10. ábra), ezért ezeket a virágokat termőrészestül eltávolítottuk. 
virágok száma

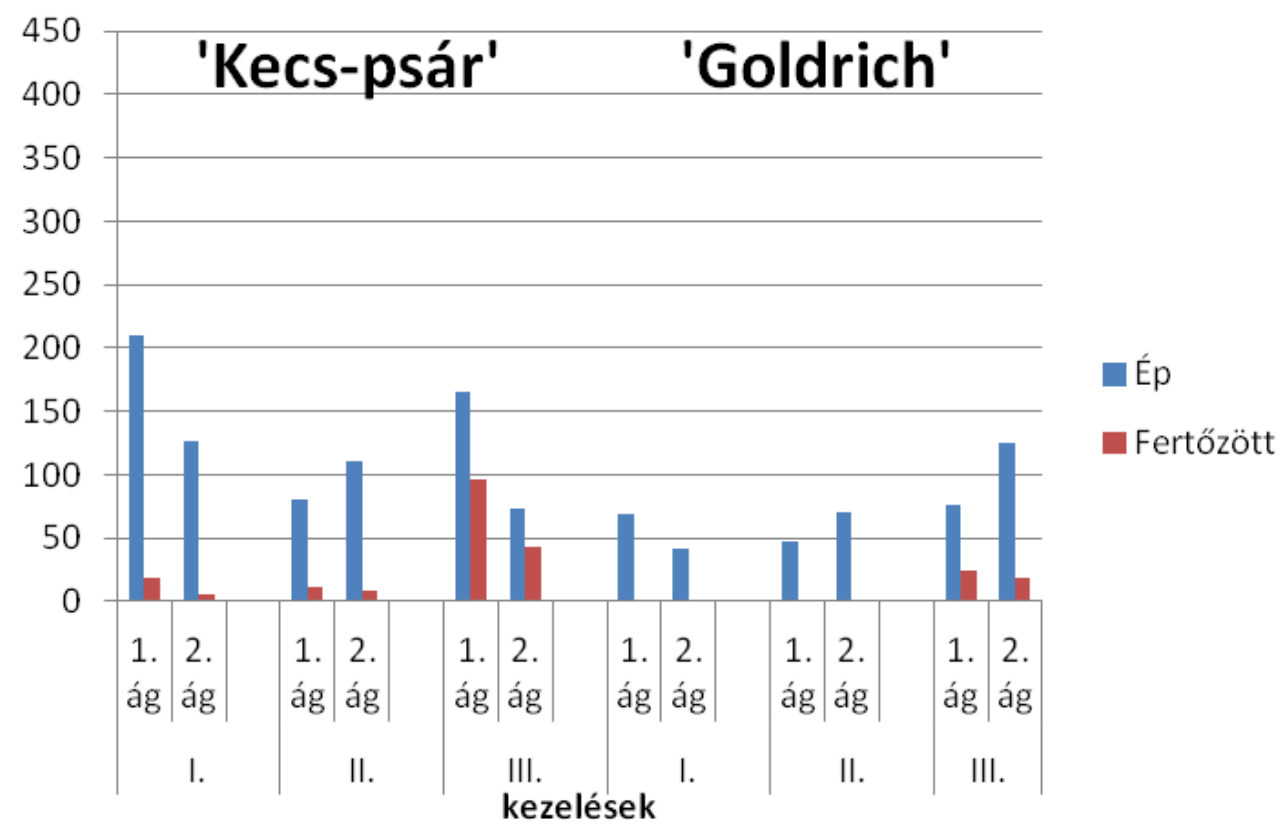

12. ábra. A 'Kecs-psár' és 'Goldrich' fajtákon kezelésenként mutatja be a grafikon az ép (kék oszlop) és fertőzött (bordó oszlop) virágok számát. Az I. kezelés: kasztrált és megporzott, II. kezelés: kasztrált és megporzatlan, III. kezelés: szabadelvirágzású ágak.

A 'Kecs-psár’ fajta vizsgálatakor a 337 kasztrált és megtermékenyített virágból 24 esetben találtunk fertőződést, a kasztrált és megporzatlan 190 virágból 20 esetben tapasztaltuk a tüneteket. A szabadelvirágzású ágakon 219 virág közül 140 esetben figyeltük meg a virágok elbarnulását, amit a háncsszövet pusztulása követett. Az egy nóduszon fejlődő virágokról - habár a fertőzéstől számított 7. napon felvételeztük - nem lehetett megállapítani, hogy ez két független virágfertőzés vagy az egyik virágról terjedt át a kórokozó a szomszédos virágra ezért ezeknél az összes fertőzött virág számát rögzítettük (12. ábra).

A kézi megporzású és megporzatlan virágok között eltérést tapasztaltunk a bibe szöveténél az öregedése során. A megporzott kasztrált virágok bibéje erősen megbarnult, a kasztrált nem porzott ágakon találhatókhoz képest. A megbarnult szövetekből nem sikerült a kórokozót visszaizolálnunk. 


\subsubsection{A bibekivonat növekedésgátló hatása az M. laxa micéliumfejlödésére}

A bibefertőzés gátlásának vizsgálatához a 'Ceglédi óriás’ fajta bibéjéből származó kivonatot M. laxa konídiumtenyészet folyékony táptalajához adtuk. A hetvenkettedik óra után szabad szemmel megfigyelhető volt, hogy a bibekivonat nem tartalmazó táptalajban összefüggő micélium tömeg nőtt. A bibekivonattal kezelt tenyészetben nem tapasztaltuk a kísérlet kezdetéhez képest eltérést. A fénymikroszkópos vizsgálat alapján megfigyeltük, hogy tizenkettedik órakor a bibekivonattal kezelt konídiumok $20 \%$-a csírázott, a kezeletlen konídiumok esetében ez az érték 70 \% volt. A csíratömlők hosszúságában ekkor nem volt eltérés megfigyelhető. Az egynapos tenyészetek vizsgálatakor a bibekivonattal kezelt micéliumok növekedése leállt, ekkora a konídiumok fele csírázott ki. Ekkor a kezeletlen tenyészetekben a micéliumok kötegekbe álltak össze, emiatt a nem csírázó konídiumokat eltakarhatták. A háromnapos tenyészetek csíratömlö fejlődés közötti eltérést mutatja be a 13. ábra.

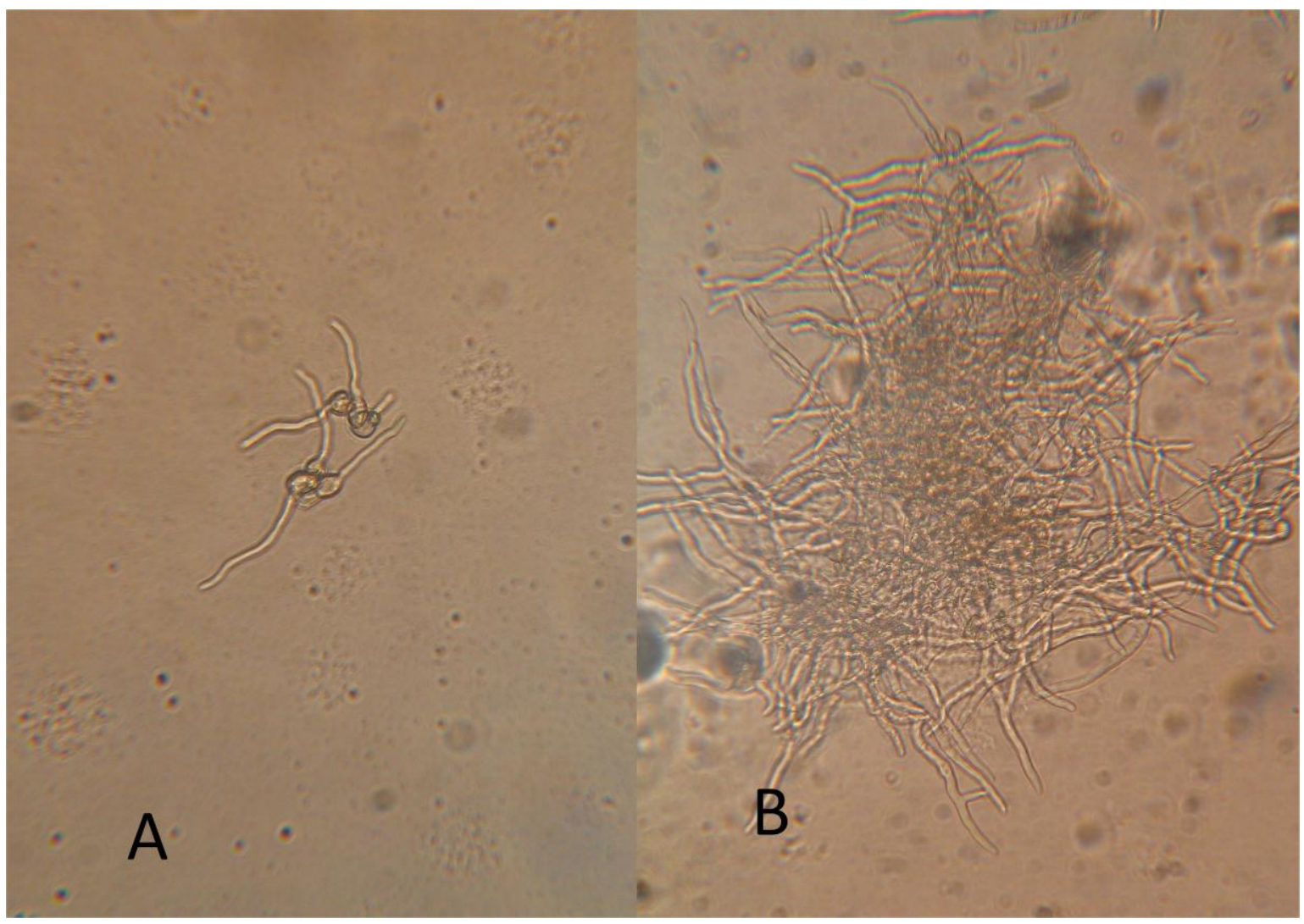

13. ábra. Bibekivonat $M$. laxa micélium fejlődésének gátlása. Háromnapos micélium tenyészetek a bibekivonatot tartalmazó (A), és kezeletlen (B) folyékony táptalajokban 300 szoros nagyításban. 


\subsubsection{A virágszirom M. laxa fertözése}

A mikroszkópos vizsgálatok alapján megfigyelhető volt, hogy a fertőzés kezdetekor a csírázó konídium a szirom felületéről az epidermisz kutikuláját és sejtfalát extracelluláris enzimeivel feloldva hatolt az felpuhult szövetekbe. A szövetbe hatoló micélium körül nem keletkezik kutikuláris perem. A mechanikai sejtfaláttöréssel szemben, a kutikula és sejtfal kémiai degradációjának tényét erősíti a belépési pont körüli bemélyedés hiánya is (14. ábra $\mathrm{F}$ kép). Az epidermisz sejtfalának felületét összefüggő papillás kutikula réteg borítja, ami a kórokozó konidiumának megtapadásának kedvez (14. ábra $E$ és $F$ kép). A szirom szöveti felépítése ad magyarázatot a gyorsan bekövetkező szöveti macerációra. A szirom színi és fonáki oldalát szimmetrikus felépítésű egyrétegű elliptikus keresztmetszetű epidermisz sejtek alkotják, közöttük nincsenek gázcsere nýlások (14. ábra A kép). Az epidermiszsejtek félgömbökhöz hasonló felületet képeznek, ami a citoplazma nyomásával szembeni vékony és laza sejtfal szerkezetével magyarázható. Két sejtsor között mezofillumszövet található. A keresztmetszeti felvétel alapján a mezofillum $50 \%$-nál nagyobb részét alkotják az intercelluláris járatai (14. ábra A kép), ami a micélium és szekretált enzimeinek gyors, korlátlan terjedésének biztosít lehetőséget (14. ábra $C$ kép). Elsőként a mezofillumsejtek plazmájának károsodása miatt a szirom vastagsága felére csökken (14. ábra D kép), amit az epidermiszsejtek pusztulása követ (14. ábra $\mathrm{B}$ kép). A micélium terjedésének irányát a sziromban a turgorukat veszített behorpadó epidermiszsejtek jelzik. 

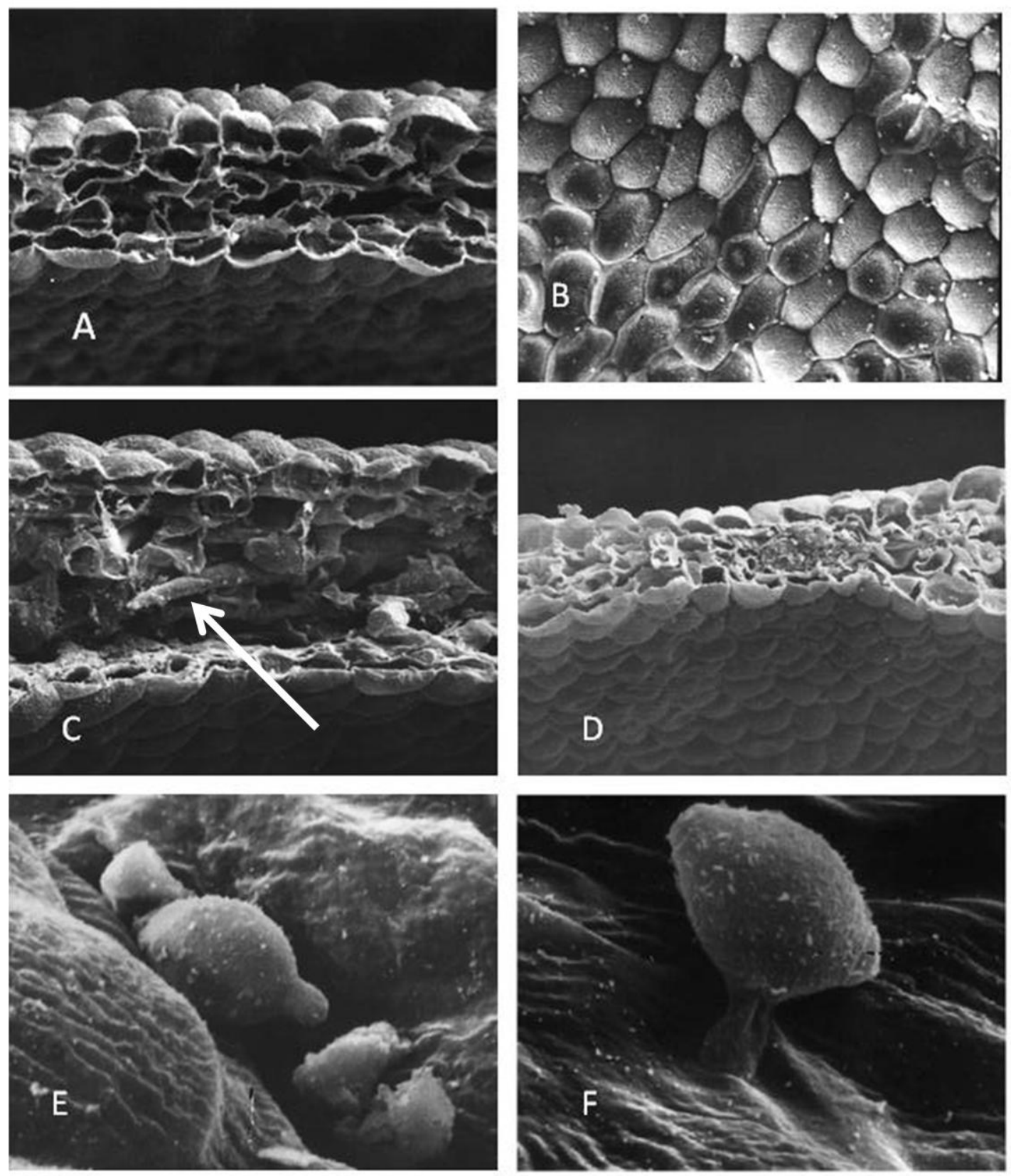

14. ábra. A ‘Goldrich’ fajta szirmának pásztázó elektron mikroszkópos felvételei.

A: Ép szirom keresztmetszeti felvétele (400x). B: M. laxa fertőzését követően a turgorukat vesztett epidermiszsejtek (400x). C: Intercellulárisok között fejlődő csíratömlő (fehér nyíl mutat rá) (1000x). D: Fertőzés következtében károsodott sejtfal (300x) E: M. laxa csírázó konídiuma (3000x). F: Kicsírázott és a szirom szöveteibe behatoló konídium (4000x). 


\subsubsection{Fajták mesterséges szirom fertőzése in vitro}

Az ültetvényből begyüjtött bimbós termőrészeket üvegházban virágoztattuk és a felnyíláskor a szirmokat PDA táptalajra helyeztük. A szirmokra egy ponton konídiumszuszpenziót juttattunk a színi oldalra.

15. ábra mutatja a kísérlet eredményeit. Minden vizsgált kajszifajta szirma 45 órával a fertőzést követően egyöntetűen kolonizálódott. A 2. 3. és 4. sorban lévő minták esetében a vizes kontroll a szirmokon nem okozott elváltozást. Kivételt képez a 'Bergeron', amely esetében a táptalajon keresztül következett be a fertőzés. A kajszin kívül $P$. cerasifera és a $P$. salicina 'Methley' egyedeinek szirmait is vizsgáltuk. A $P$. cerasifera esetében 45 órával a fertőzést követően a sziromszövetek $30 \%$-át fertőzte meg a gomba. A japánszilva minták esetében 7 órával a fertőzés után a fertőzési csepp körül 3-4 mm-rel nagyobb, vizenyős folt jelent meg az összes fertőzött szirmon, ami arra utal, hogy a japánszilva szirmai nem mutattak nagyobb ellenállóságot a vizsgált kajszik átlagához képest. Az 'Orange red' fajta szirmán több pontból kezdődött a szövetbarnulás, ami a szirmok természetes fertőződésével magyarázható. A második felvételezéskor, a 'Zard' fajta szirmain volt a legcsekélyebb, a 'Baneasa 4/11', 'Orange red', 'Marculesti 18/6' és a 'Mandulakajszi' fajtákon mérsékelt míg a 'Forum', 'Sulmonax', 'Aurora', 'Korai zamatos', 'Gönci magyarkajszi’, 'Bergeron' és 'Ceglédi Piroska' fajtákon a legerősebben jelentkezet a fertőzés. A legnagyobb eltérés a vizsgált kajszifajták között huszonnyolc órával a fertőzés után volt megfigyelhető. Hat fajta az 'Orange red', 'Gönci magyarkajszi','Bergeron', 'Sulmonax', 'Korai zamatos', 'Forum' esetében nem volt megfigyelhető ép rész. A 33. óra után a kajszifajták közül csak a 'Zard' és 'Marculesti 18/6' szirmokon volt még ép szöveti rész. A fertőzést követő 45 óra elteltével nem volt ép sziromszövet egyetlen vizsgált kajszifajta esetében sem. A kajszifajták sziromlevelein különböző sebességgel történt a fertőzés, az első teljesen kolonizált szirmok a fertőzést követő 28. órában jelentek meg, míg a legkésőbb elpusztult szirmok 45 órával a fertőzést követően felvételeztük. A vízzel kezelt szirmok (15. ábra pirossal keretezett szirmok) a 45 óra elteltével sem mutattak szövetpusztulást. 


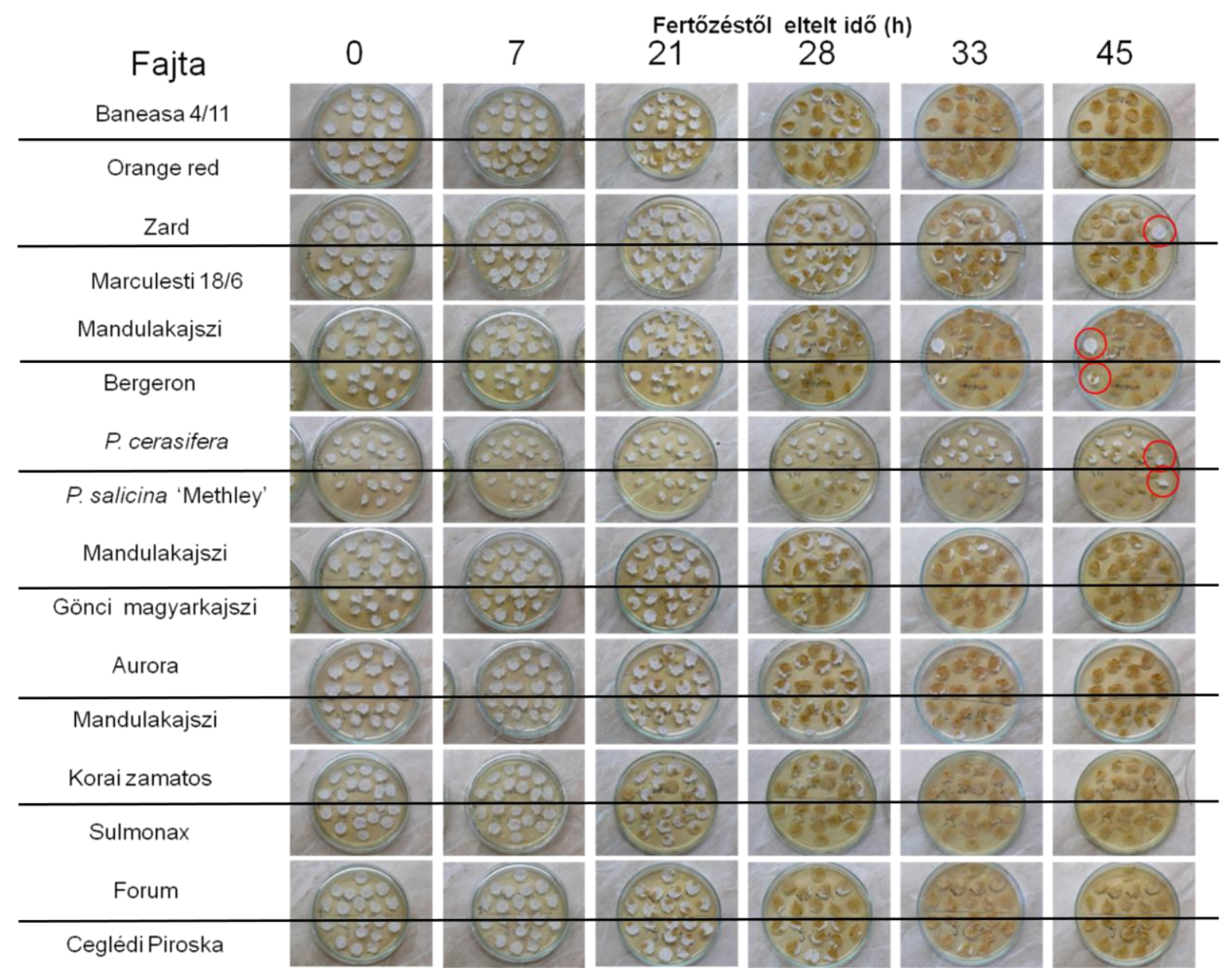

15. ábra. Kajszi, cseresznyeszilva és japánszilva szirmok mesterséges fertőzése Monilinia laxa konídium szuszpenziójával. Minden petricsészében két fajta 10-10 szirom fertőzése követhető nyomon vízszintes elrendezésben. A fertőzéstől eltelt órák száma az oszlopok felett található. Az utolsó oszlopban piros keret jelzi a vízzel kezelt kontroll szirmokat. 


\subsubsection{A bibe kórokozóval szembeni ellenállóképességének in vitro vizsgálata}

A PDA táptalajon nevelt $M$. laxa tenyészetek csökkent fejlődését figyeltük meg a táptalajra helyezett bibe környezetében. A bibe körül a kórokozó fejlődése a koncentrikus növekedése során rövid ideig gátlást szenvedett, a légmicéliumok fejlődése ezen a részen lelassult. Később ez a lemaradás a gomba fejlődésében teljesen eltűnt. A termő és a bibe kolonizációja során a bibe, a természetes fertőzéshez hasonló módon, képes volt hosszabb ideig ellenállni a kórokozó macerációjának. A bibéből szekretálódó ribonukleázok működését a Torula RNS bomlása jelzi. Az RNS toluidinkékkel történő festésekor a bibe körül fehér folt jelzi a ribonukleinsav bomlását (16. ábra). Ennek a foltnak a mérete megközelítette a micélium fejlődést gátló zóna méretét. A bibeszövet fokozott ellenállóképessége és a táptalajon a gomba korlátozott növekedése alapján feltételezhetjük a bibében kifejeződő ribonukleázok gombafejlődést gátló hatását.
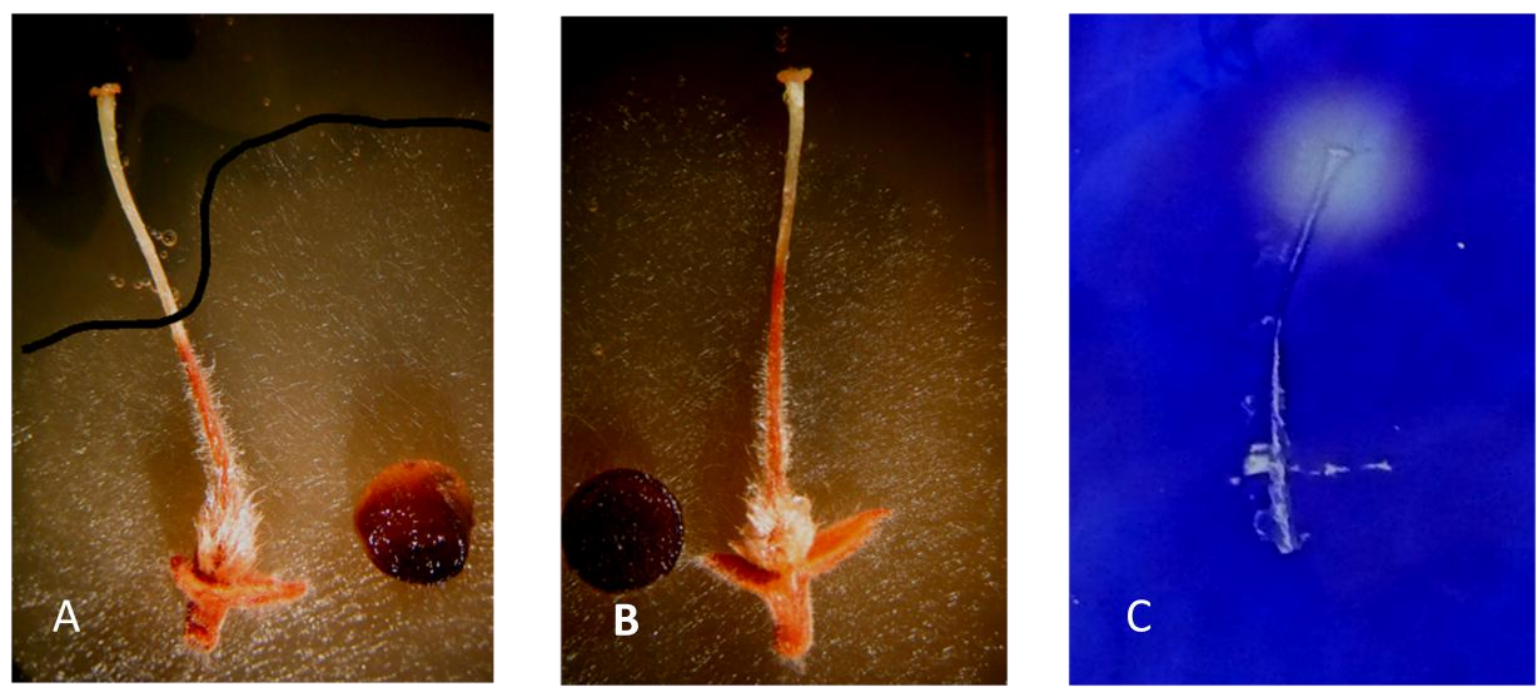

16. ábra. A táptalajon fejlődő $M$. laxa fejlődésének gátlása a bibe körüli régióban. 'A': A micélium fejlődésének körvonalát a fekete sávval jelöltük. 'B': Megfigyelhető a bibe fokozott ellenállósága a kórokozó szövet macerációjával szemben. 'C': A Torula RNS degradácója toluidinkék festéssel mutatható ki a bibe környékén a táptalajba diffundált ribonukleázok hatására. 


\subsubsection{Ellenállóság vizsgálata a 'Zard' $\times$ 'Korai zamatos' család egyedein mesterséges vesszőfertőzés alapján}

Az ültetvényben történt fertőzéskor $M$. laxa micéliummal átszőtt agarkorongokat helyeztünk a vesszőkön vágott sebekre. Kontrollként steril agarkorongokat használtunk, aminek eredményeként nem tapasztaltuk a fertőzési tünetek kialakulását, mindkét fajta esetében egy kalluszosodó, megvastagodott sebgyógyulást kaptunk. A fertőzés hatására a vesszőkön, a levélalapokon kialakultak az exogén sztrómák, amik konídiumokat füztek le. A 2 mm-nél kisebb átmérőjü vesszők fertőzésekor a kórokozó körbenőtte a floémot, ennek következtében a fertőzés felett található részek teljes hosszban elhervadtak. Mivel ezeknek a vékony vesszőknek a fertőzése más eredményt (vesszőhossz pusztulás) hozott, mint a vastagabb vesszőké, ezért ezeket a fertőzéseket nem vettük figyelembe az adatok elemzése során.

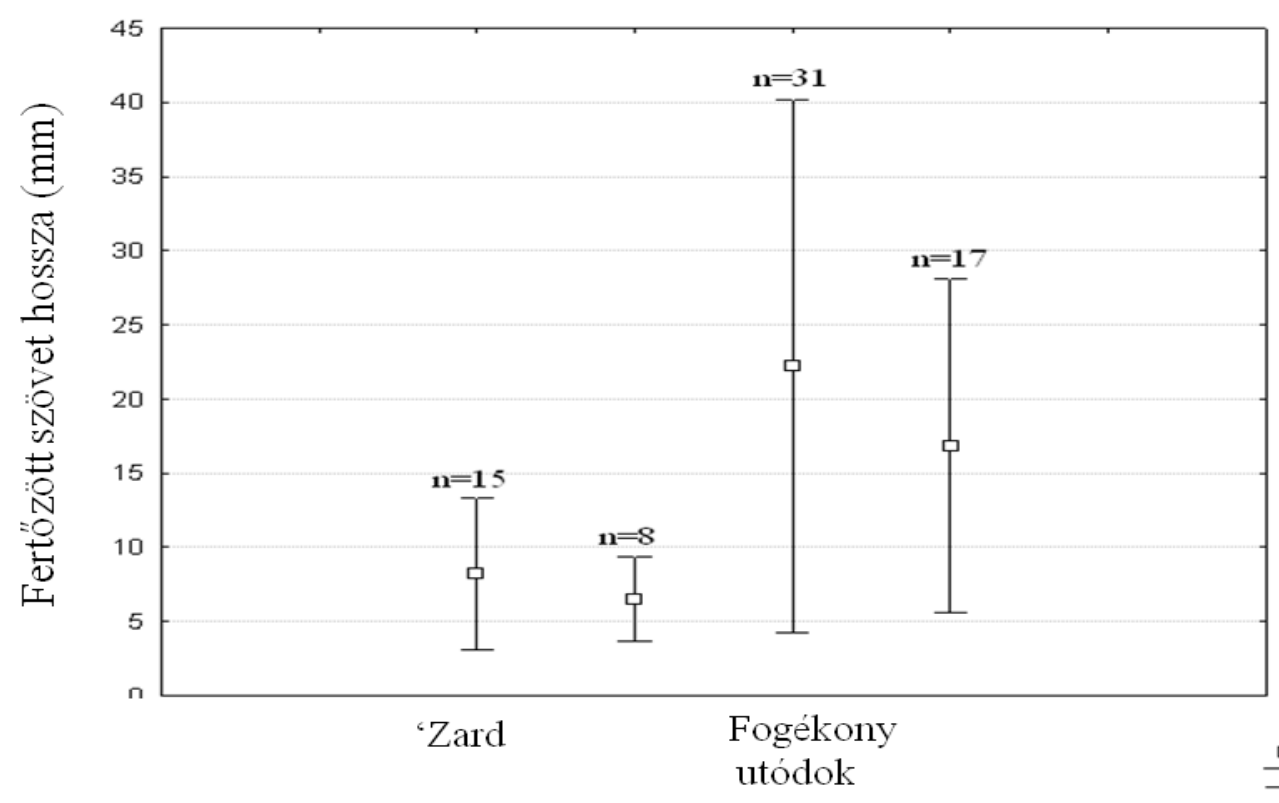

$\begin{array}{ll}\text { 'Korai } & \text { Ellenálló } \\ \text { zamatos' } & \text { utódok }\end{array}$

17. ábra. A 'Korai zamatos' és 'Zard' fajták és hibridjeik fertőzött szövethossz alapján történő összehasonlítása. Az utódokat fertőzésre adott válaszreakciójuk alapján ellenálló és fogékony csoportokba soroltuk. Az n érték a két szülő fajta esetében a fertőzések számát az utódok esetében a fertőzött egyedek számát mutatja.

A mesterséges fertőzés a két szülőfajtán nem várt eredményt hozott. Az elpusztult vesszőszövetek hossza és a természetes fertőzés alapján tapasztalt fenotípus között ellentmondás mutatkozott. A szabadföldi felvételezések alapján ellenállónak tartott 'Zard' 
fajta vesszőin az átlagos fertőzött szövethosszúság nagyobb volt, mint a fogékony 'Korai zamatos' fajta esetében tapasztalt érték, habár nem volt szignifikánsan kimutatható eltérés a t-próba alapján a két szülőfajta között (17. ábra).

A felvágott vesszők sztereomikroszkópos vizsgálata alapján biztosan elkülöníthető válaszreakciót tapsztaltunk. A 'Korai zamatos' fajta esetében a fertőzött szövet és az ép szövet között egy elmosódó átmenet volt megfigyelhetö, míg a 'Zard' fajta estében az összes fertőzésnél határozott, élesen elkülöníthető volt az ép és fertőzött rész. A rezisztens 'Zard' esetében a fertőzés határánál az ép szövetrész megvastagodását lehetett megfigyelni (18. ábra).

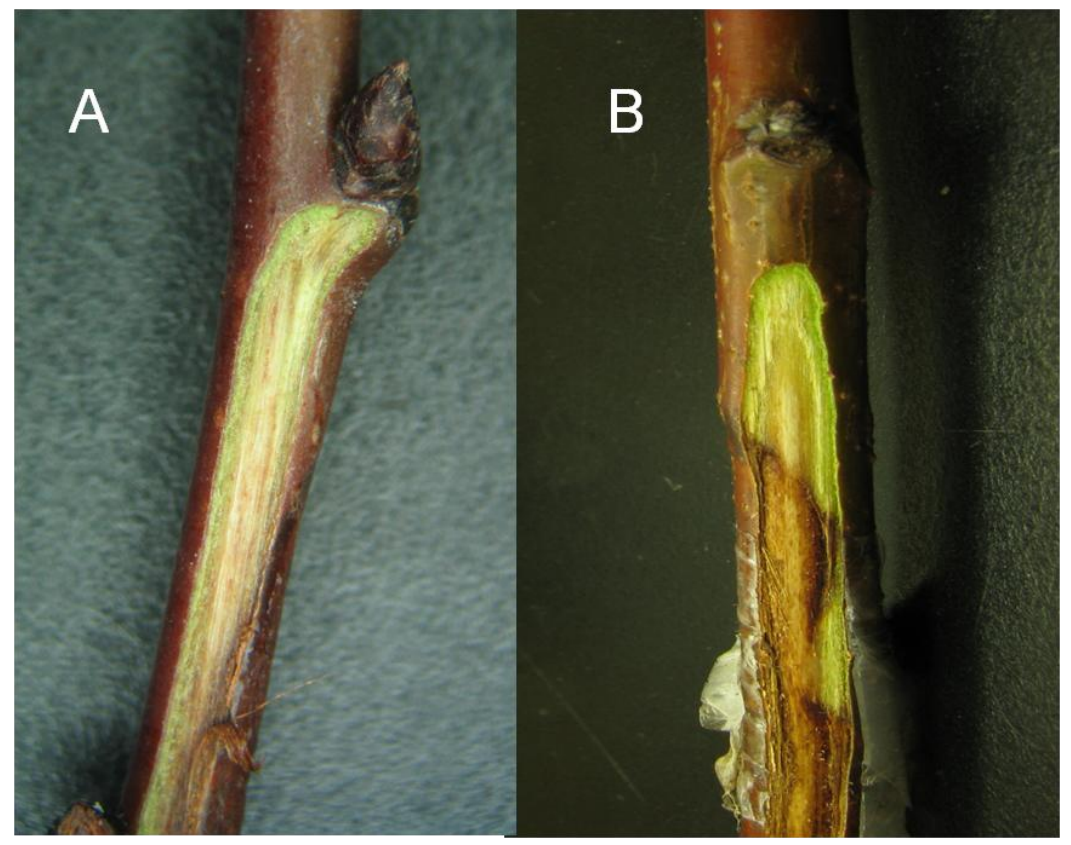

18. ábra. A: 'Korai zamatos' vesszőjének mesterséges $M$. laxa fertőzése. A fertőzött és ép háncsszövet között átmenet figyelhető meg, ami a kórokozó folyamatos terjedését jelzi. B: 'Zard' fajta vesszőjének válaszreakciója a mesterséges $M$. laxa fertőzésre. Az ép és fertőzött rész élesen elkülönül, a fertőzés határán a háncsszövet megvastagodása figyelhető meg.

A 'Zard' fajta estében is megfigyelhető volt a háncsszövet pusztulása. A kórokozót sikeresen izoláltuk a fertőzött háncsszövetböl, a negatív kontrollként megsebzett és steril agarkoronggal tesztelt sebzésekről viszont nem. A fertőzött vesszők levélalapjain általános volt a gomba exogén sztrómáin tömegesen megjelenő szürke konídium tömeg (19. ábra). 


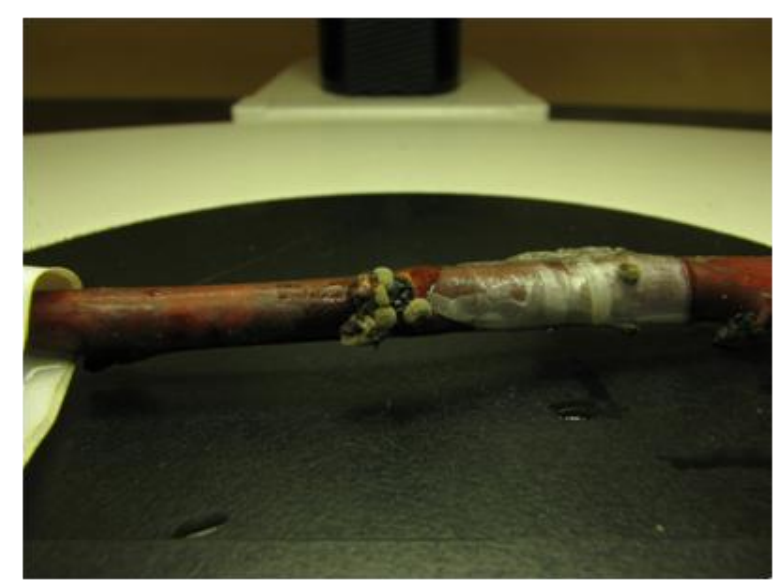

19. ábra. A 34-es hibrid vesszőfertőzése során a levélalapokon exogén sztrómák fejlődtek.

\section{Rezisztens hibridek}

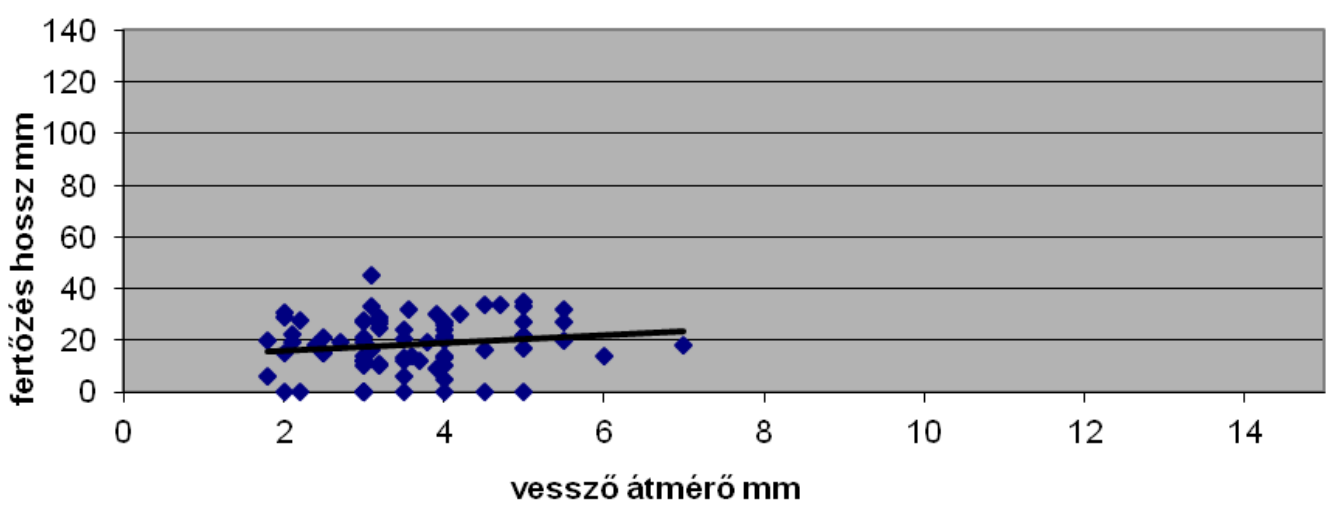

Fogékony hibridek

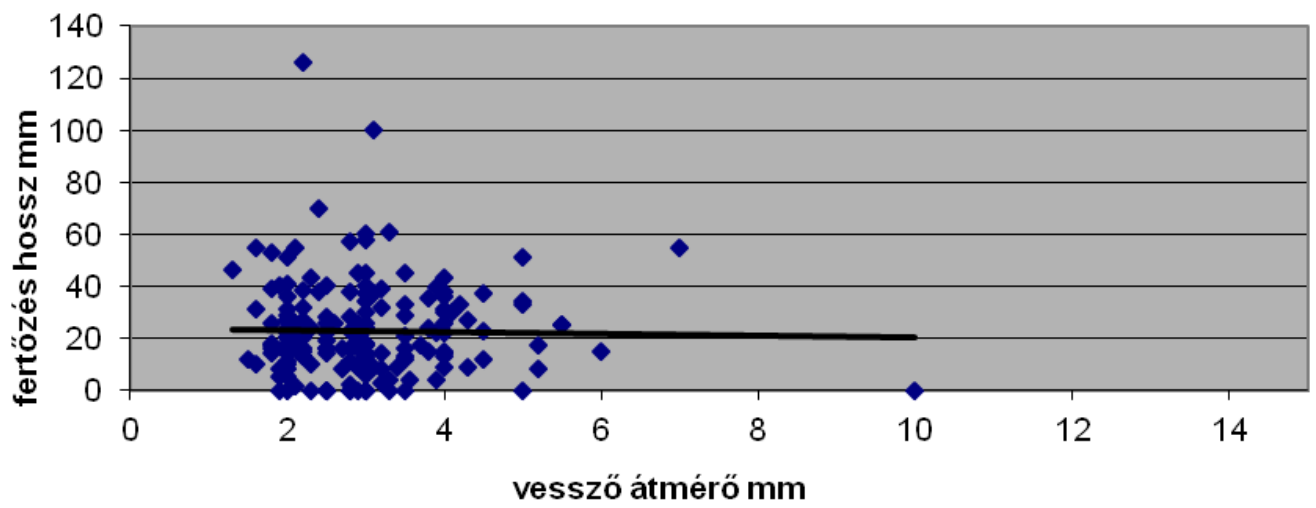

20. ábra. A fogékony és ellenálló hibridek fertőzéshossz és vesszőátmérőjének bemutatása. 
A fertőzés hatására adott válaszreakciók alapján (18. ábra), a 'Korai zamatos' $\times$ 'Zard' család utódjaiból 17 egyedet ellenállónak, míg 31 egyedet fogékonynak határoztunk meg. Mivel a fogékony és ellenálló egyedek pusztult vesszőhosszaiból származó adatsorok átlagának összehasonlítására alkalmas parametrikus t-teszt feltételei nem teljesültek (varianciák homogenitása, Levene-teszt p<0,05; adatok normál eloszlása, Shapiro-Wilk teszt $\mathrm{p}<0,05$ ), ezért a parametrikus tesztnél gyengébb, nem-parametrikus statisztikai teszteket alkalmaztunk. A fogékony és ellenálló egyedek fertőzött vesszőrészének hossza szignifikáns eltérést mutatott. A szenzitíveknél átlagosan 22,5 mm-t, míg a rezisztenseknél 17,5 mm-t mértünk (Mann-Whitney-test $Z=1,9858, p=0,047$ és Welch-test $d=2,838$, p=0,007) (17. ábra). Az összes vesszőn mért fertőzéshossz és a vesszők átmérője között

nem volt szignifikáns korreláció (Spearman-korrelació $\mathrm{r}=0,0458, \mathrm{p}=0,12$ ), sőt a fertőzéshossz gyakorlatilag nem változott a vesszőátmérő eltérésével (20. ábra).

\subsubsection{A 'Zard' és 'Orange red' fajták ellenállóságának összehasonlítása a fiatal levelek mesterséges fertőzése alapján}

Az ültetvényben tapasztalt levélfertőzési tünetek alapján megkíséreltük a két fajta leválasztott leveleinek fertőzését. Az 'Orange red' fajta esetében a természetes fertőzés során a fertőzött virágok és hajtások felületén keletkezett exogén sztrómák körül elhelyezkedő leveleken apró barna léziókat, majd az egész levéllemezt elterjedő barna pusztulást figyeltünk meg. Ezeket a tüneteket a 'Zard' fajta levelein nem tapasztaltuk. A két fajta közötti eltérést a 21. ábra szemlélteti. Az 'A' kép és ' $B$ ' kép felső három levele az 'Orange red' fajtáról származik, míg a 'Zard' fajta leveleit a 'B' kép alsó fele mutatja be. Az 'Orange red' esetében már a fertőzést követő 48 órára teljes felületen pusztult a levelek $30 \%$-a, míg a 72. órára az összes levél teljesen kolonizálódott. A 'Zard' fajta esetében 72. órára alakultak ki a tünetek, de ez maximálisan a levelek felületének $15 \%$-ára terjedt ki. A negatív kontroll leveleken nem tapasztaltunk fertőzést ('C' kép). Az 'Orange red' leveleken a gomba exogén sztrómáin konídiumokat fejlesztett. 

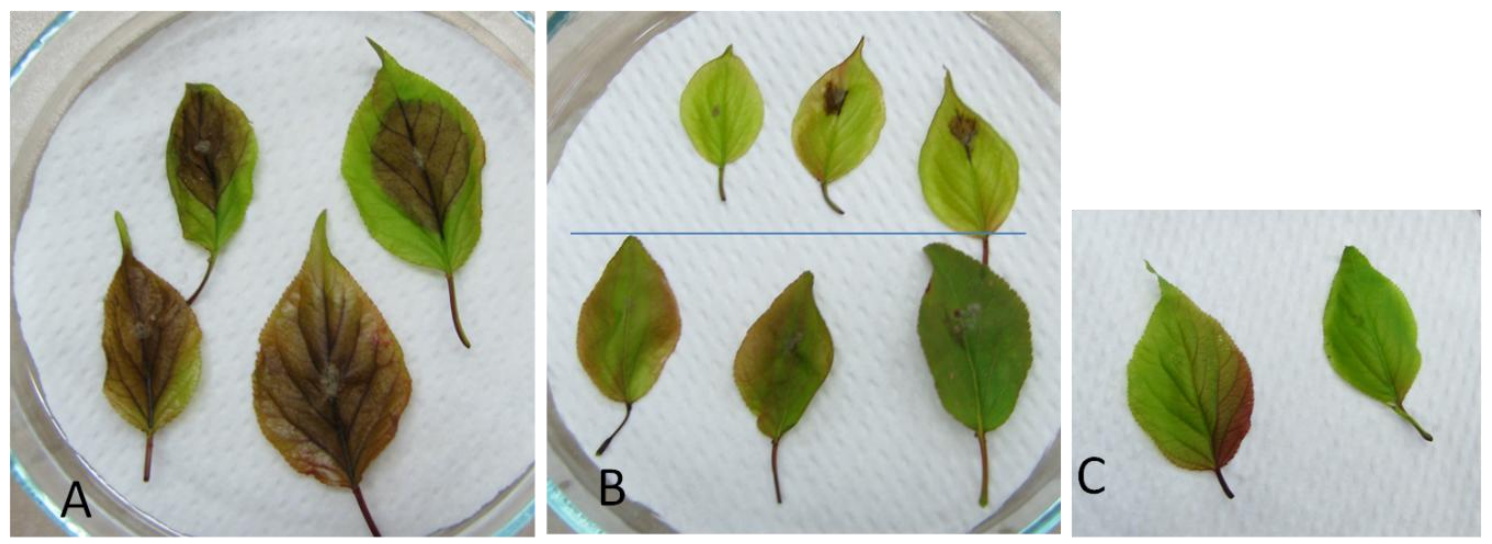

21. ábra. Két kajszifajta mesterséges $M$. laxa levélfertőzése. 48 órával a fertőzést követően az 'Orange red' ('A' kép és 'B' kép felső része) fajta levelein a megbarnult részeket kolonizálta a gomba. A 'Zard' fajta ('B' kép alsó fele) esetében nem látható fertőzött rész kialakulása. A negatív kontroll leveleken 48 óra elteltével ('C' kép) nem történt elváltozás egyik fajta esetében sem.

\subsection{Molekuláris vizsgálatok}

\subsubsection{Eltérő fogékonyságú kajszifajták összehasonlítása NBS LRR típusú rezisztenciagén-analógok SSCP vizsgálata alapján}

A monilia-ellenállósághoz kapcsolt molekuláris marker kifejlesztésének érdekében elsőként a növényvilágban legelterjedtebb rezisztenciagéncsaládon belüli változékonyságot vizsgáltuk. A vizsgálat alapja a különböző növényfajokból izolált rezisztenciagének konzervált szekvenciarészeinek hasonlósága, emiatt a módszer alkalmazása mindennemü elözetes szekvenciaismeret nélkül alkalmazható bármilyen növényfajon. A konzervált szekvencia szakaszokat kilenc rokonságilag távol álló fajból izolált 26 NBS-LRR rezisztenciagén NBS domén aminosav-szekvenciája alapján választottuk ki. Mivel a géneknek az NBS doménon kívül nem volt egyöntetü, legalább 8 aminosav-egyezést mutató szakasza, így a gének TIR vagy CC és LRR doménjaira nem terveztünk indító szekvenciákat. Az illesztés alapján a Kináz II motívum C terminálisán a CC-NBS-LRR csoportba tartózó szekvenciákban egy triptofán aminosav található, míg a HD motívum $\mathrm{N}$ terminálisán $89 \%$-os valószínüséggel cisztein (22. ábra). Mivel korábban kajsziból kizárólag TIR-NBS-LRR típusú RGA-kat izoláltak, a CC-NBS-LRR típusú szekvenciákra specifikus primereket terveztünk. A degenerált primer tervezésénél a permutációs index értékét nem maximalizáltuk az értéket (22. ábra). 
Motívumok

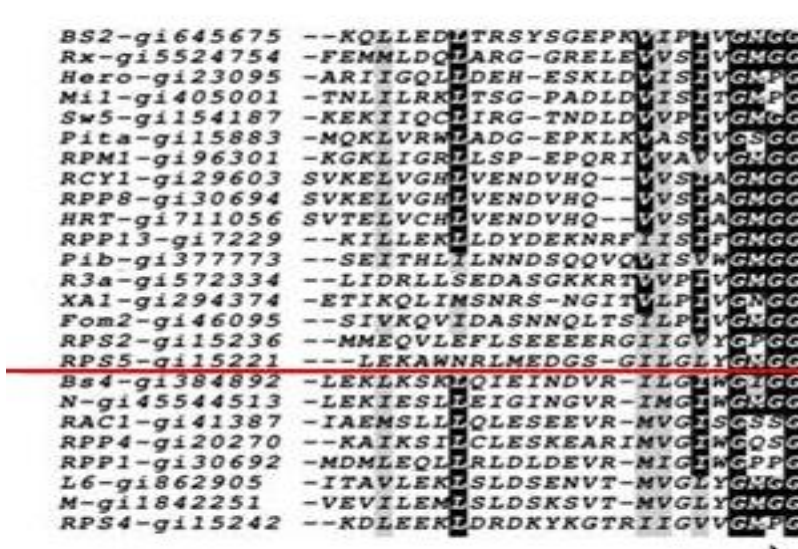

Primer
P-hurok

P-loop F
Kináz 2 domén

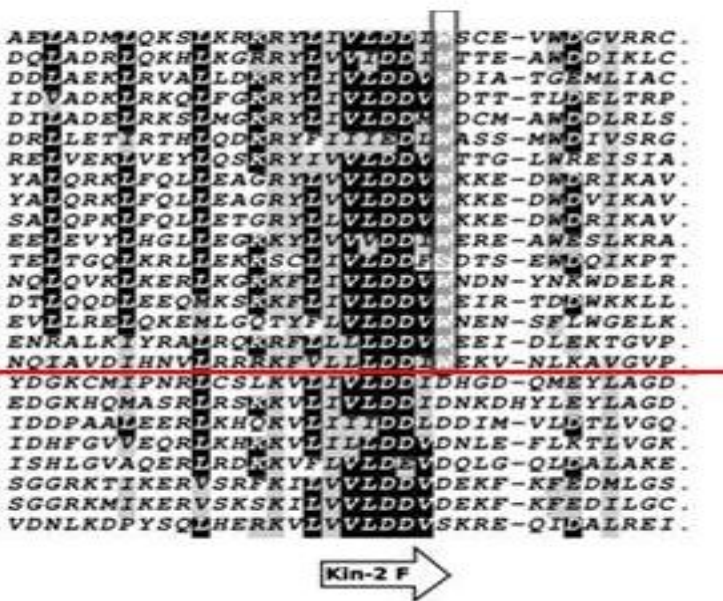

Motívumok

Hidrofób domén

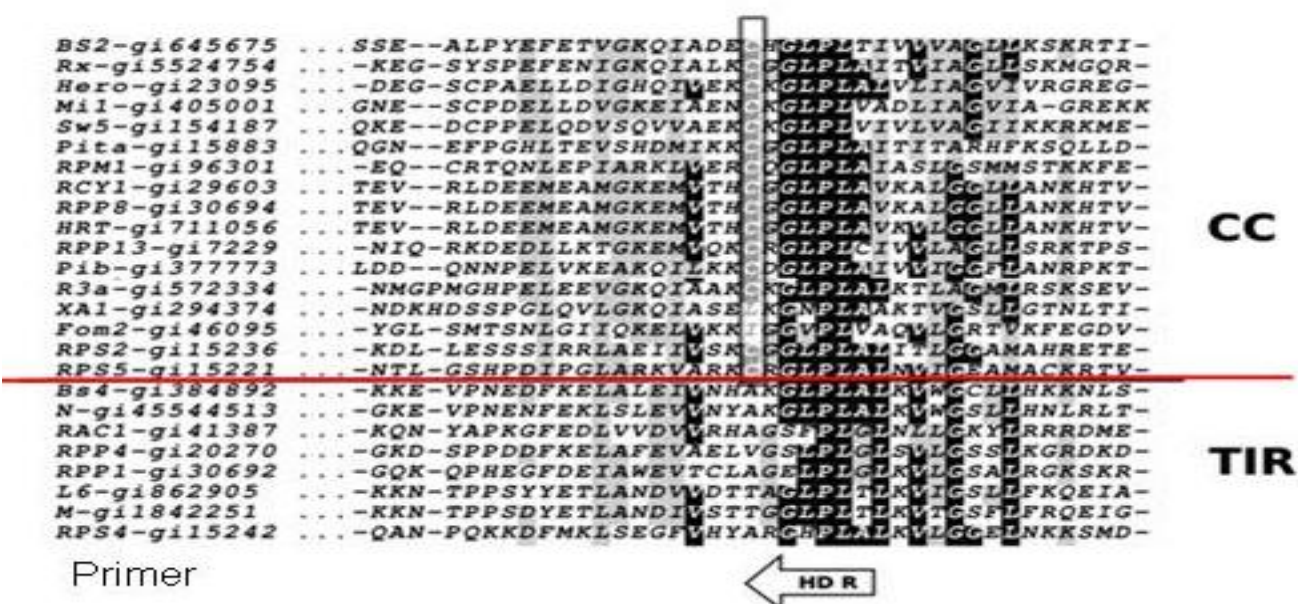

22. ábra. Az NCBI adatbázisból származó 26 aminosav-szekvencia illesztése alapján az NBS domén 3 konzervált régiója, amelyekre a primereket terveztük. A felső 18 szekvencia CC-NBS-LRR, az alsó 8 pedig TIR-NBS-LRR típusú RGA-kból származik. A fekete alapon látható aminosavak a P-loop, Kináz II és hidrofób 
Az összes lehetséges primerkombinációval gradiens PCR-t végeztünk a 'Goldrich' fajta genomi DNS-én, és kiválasztottuk a várt méretben határozottan megjelenő fragmentumokat adó legmagasabb tapadási hőmérsékletet. A primerkombinációk alkalmasságát a 23. ábrán bemutatott gélkép alapján választottuk ki. Fontos megemlíteni, hogy a CC-NBS-LRR szekvenciára specifikus, saját tervezésű CUB-Kin2 F és CUB-HD R primerkombináció alkalmazásakor a várt 250 bp hosszúságú PCR terméket kaptuk (23. ábra E primerkombináció), ami alapján feltételeztük a CC-NBS-LRR rezisztenciagén analógok jelenlétét a kajszi genomban. A CUB-Kin2 F és a korábban publikált LM367 R primerkombináció alkalmazásakor nem kaptunk terméket (23. ábra $\mathrm{F}$ primerkombináció), ami magyarázatot adott a CC-NBS-LRR típusú génanalógok korábbi kimutatásának hiányáról a kajszi esetében.

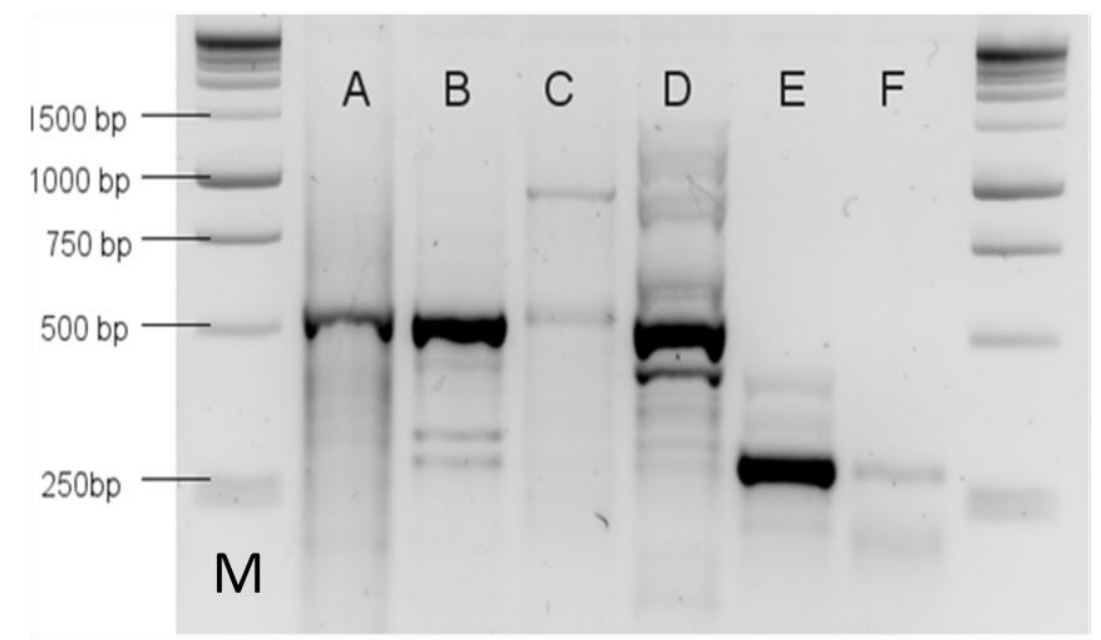

23. ábra. $A$ 'Goldrich' kajszifajta NBS doménjára tervezett primerek PCR analízise. $A$ : CUB-P-loop F és CUB-HD R, B: P-loopGent F és LM637 R, C: CUB-P-loop F és LM637 R, D: P-loopGent F és CUB-HD R, E: CUB-Kin2 F és CUB-HD R, F: CUB-Kin2 F és LM637 R primerkombinációk. M: 1-kb + DNS-marker.

Ezen eredmények alapján megállapítható volt, hogy a tervezett primerek nagyobb degeneráltsági foka miatt nagyobb számban lehet a kajszigenom egymástól eltérő NBS szekvenciáit meghatároznunk. A primerkombinációk közül a saját tervezésü CUB-P-loop F és CUB-HD R, a P-loopGent F és LM637 R indítószekvenciákkal készült polimeráz láncreakció termékeit pGemT-Easy vektorba ligáltuk, és E. coli JM 109 kompetens sejtekbe klónoztuk. A klónok szekvenciájában vizsgáltuk a CC-NBS-LRR géncsaládra jellemző Kináz II motívum végén található triptofánt kódoló TGG triplet jelenlétét a CUBKin2 F primer és az eredeti reverz primerek semi-nested polimeráz láncreakció 
alkalmazásával. A Soriano és mts. (2005) által alkalmazott primerkombinációból származó 96 klón esetében a semi-nested kolónia PCR technikával egyetlen esetben sem kaptuk a várt CC-NBS-LRR-re jellemző fragmentum méretet, míg a saját tervezésű primerkombináció esetében a 96 klónból 28 esetben a 250 bp hosszúságú DNS fragmentum szaporodott fel. Az egyedi klónokból származó PCR termékek között agaróz gélen nem lehetett hosszpolimorfizmust kimutatni, ezért a szekvencia alapú különbségek kimutatására alkalmas SSCP technikát alkalmaztuk. A 28 pozitív klónból az SSCP vizsgálat alapján 11 eltérő futtatási mintával rendelkező klónt választottunk ki szekvenálásra. (24. ábra).

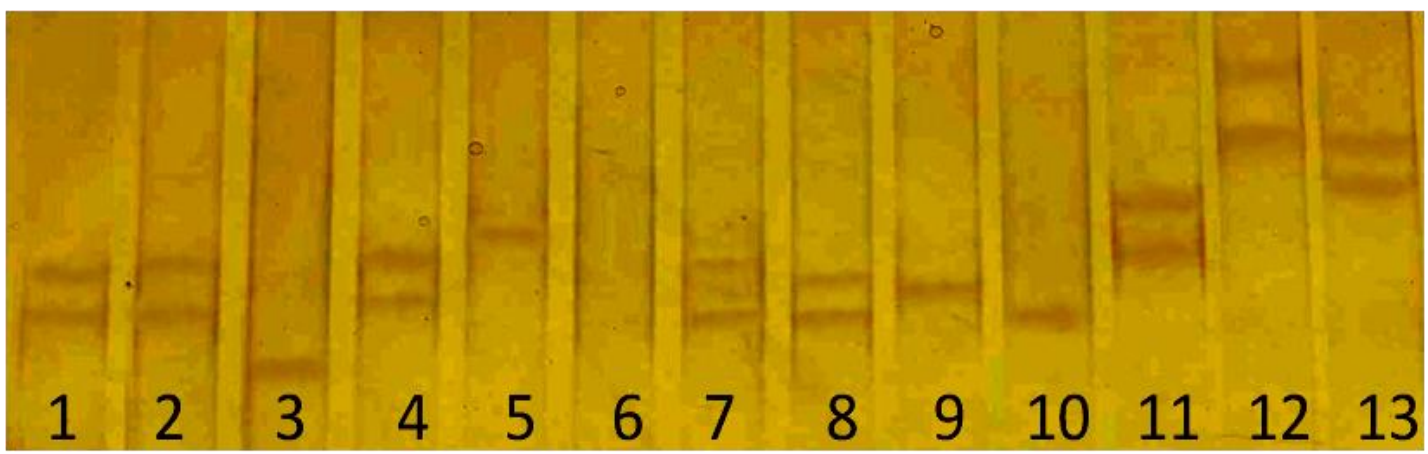

24. ábra. 1-11. A CC-NBS-LRR szekvencia specifikus pozitív kolónia PCR-termékek eltérésének kimutatása SSCP technikával. 12-13. minta a két TIR NBS RGA klón.

Két olyan negatív klón szekvenciáját is meghatároztuk, amelyek egyértelműen a TIR-NBS-LRR géncsaláddal mutattak nagy hasonlóságot. A megszekvenált 13 eltérő nukleinsav-szekvencia transzlált aminosav-szekvencia illesztését a 25. ábra mutatja be. A CC-NBS-LRR szekvenciákra jellemző Kináz II domén N terminálisán található triptofánt (W) az illesztésen piros kerettel jelöltük 


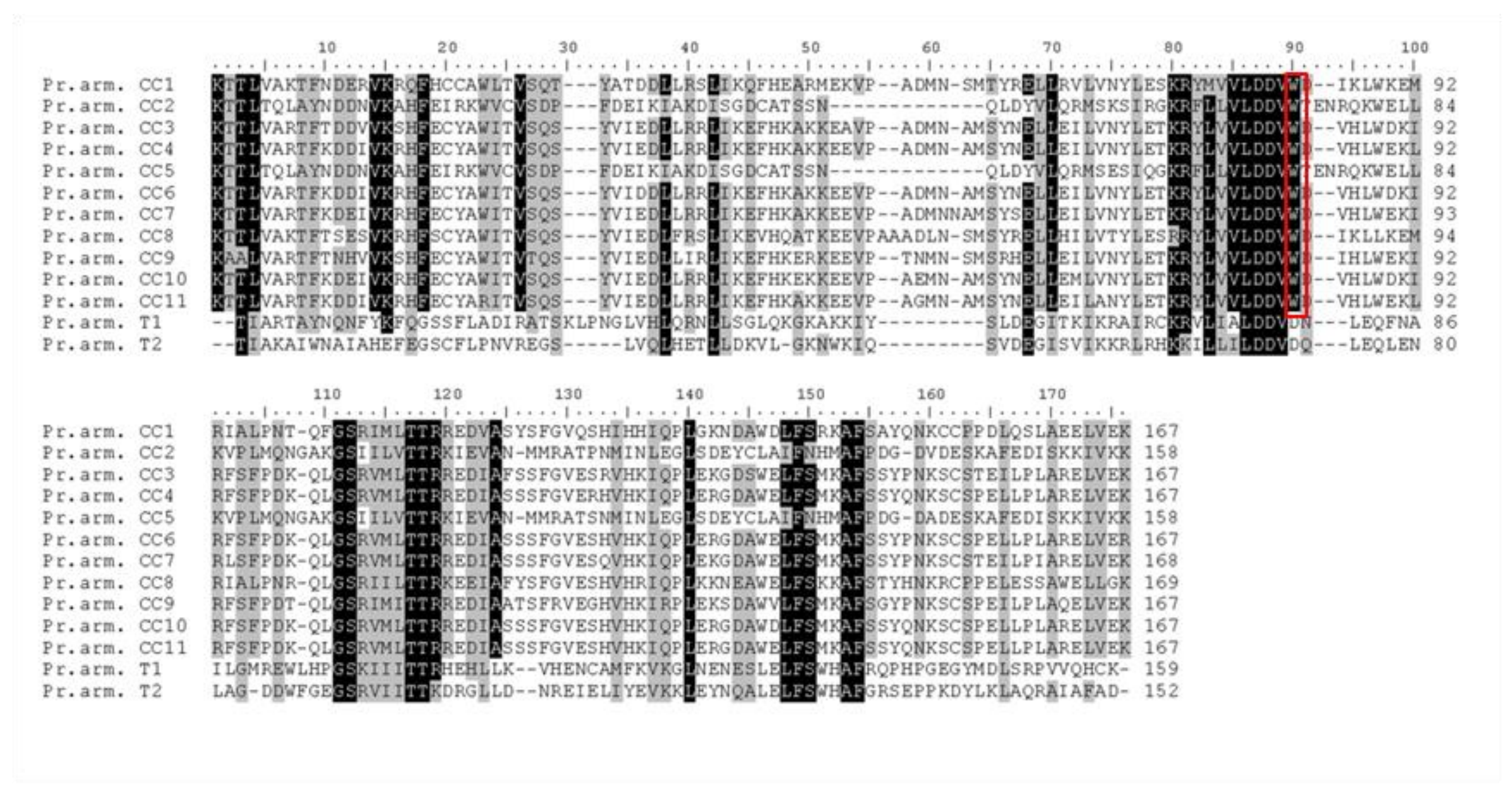

25. ábra. Tizenegy kajszi CC-NBS-LRR és két TIR-NBS-LRR aminosav-szekvencia illesztése. 
A szekvenciákat (PaCC1-PaCC11 és PaT1-PaT2) az NCBI adatbázisba a következő azonosító számokon tettük közzé: GQ336813 - GQ336825. A szekvencia-illesztések alapján megállapítható, hogy a kajsziban eddig nem ismert CC-NBS-LRR géncsaládhoz tartozó szekvenciákat sikerült meghatároznunk. A tervezett primerek alkalmazásával mindkét NBS-LRR típusú géncsalád tagjait tudjuk vizsgálni a kidolgozott PCR technikával, ezáltal szélesebb körben lehet felfedni a NBS domén szekvenciáit a kajszi genomban.

A vizsgált fajták közül természetes fertőzés alapján kiválasztottuk az 'Aurora', 'Orange red', 'Goldrich', 'Harcot', 'Korai zamatos', 'Ceglédi Piroska', 'Ceglédi bíbor' fajtákat, mint moníliára fogékony genotípusokat, míg ellenálló kajszigenotípusként a 'Zard' fajtát alkalmaztuk. A fajtákat két primerkombinációval - CUB-P-loop F és CUBHD R, illetve P-loopGent F és LM637 R vizsgáltuk. A PCR termékek között agaróz gélelektroforézis során nem tapasztaltunk hosszpolimorfizmust. Mivel a klónok SSCP vizsgálata korábban sikeresen felfedte a felszaporított DNS szakaszok változékonyságát, az ellenálló és fogékony fajták NBS szekvenciák közötti eltérést ismételten az egyszálú konformáció-polimorfizmus módszerével vizsgáltuk. Egyértelmüen megfigyelhető a gélek alapján, hogy az általunk tervezett primerkombináció alkalmazásakor összesen 31 felszaporított DNS szakaszt nyertünk, míg a kisebb degeneráltsági fokkal rendelkező PloopGent $\mathrm{F}$ és LM637 R primerkombináció esetében az összes fajtára nézve 13 elkülöníthető fragmentum keletkezett (26. ábra). Mivel egyik primerkombináció esetében sem találtunk kizárólag az ellenálló 'Zard' fajtára jellemző fragmentumot, megállapíthatjuk, hogy habár a kidolgozott technika a vizsgált fajták között egyértelmü változékonyságot mutatott $\mathrm{ki}$, az NBS domén szekvenciáját tekintve, nem sikerült a monilia-ellenállósághoz kapcsolt allélt meghatároznunk. Ezen eredmény alapján természetesen nem lehet kizárni, hogy a monilia rezisztenciát nem NBS-LRR típusú rezisztenciagén okozza, de megállapítható, hogy a közel 60 NBS szekvencia között nem volt a rezisztens fajtában egyedileg megjelenő DNS-fragmentum. 

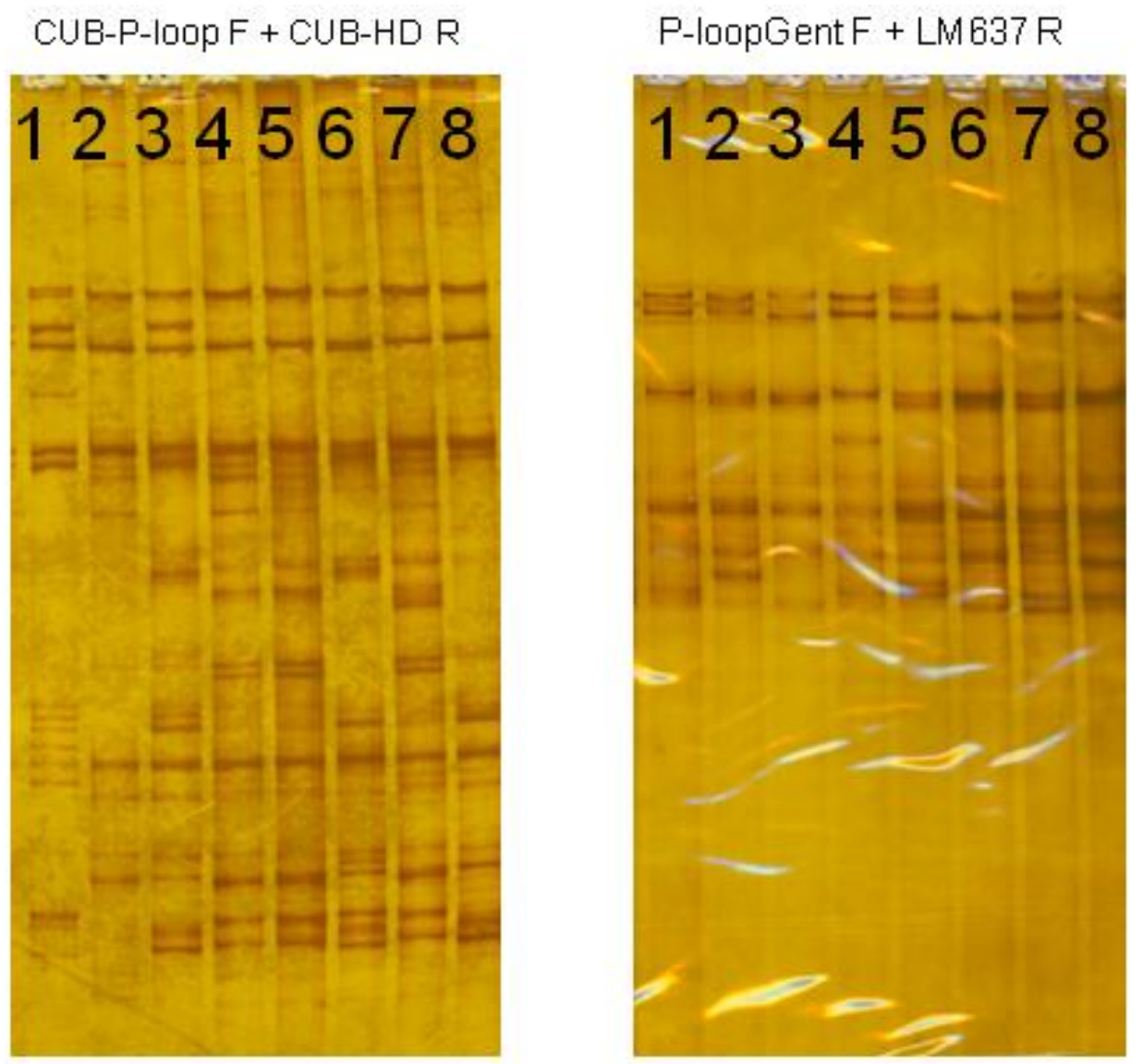

26. ábra. A hét moniliára fogékony fajta 1: 'Korai zamatos', 2: 'Goldrich' 3: 'Harcot', 4: 'Ceglédi Piroska', 5: 'Aurora' 6: 'Ceglédi bíbor', 7: 'Orange red', - és az ellenálló 'Zard' kajszifajta NBS-LRR típusú rezisztenciagénekre specifikus PCR-termékek eltérésének kimutatása egyszálú konformáció-polimorfizmus technikával. A két primerkombináció közül a baloldali akrilamid gélen összesen 31 fragmentum, a jobboldali gélképen 13 fragmentum volt elkülöníthető. A 8. számú 'Zard' mintában nem található egyedi fragmentum, ezért ezek az RGA szekvenciák nem kapcsolhatóak a monilia-rezisztenciához.

\subsubsection{A kajszi NBS LRR RGA-k filogenetikai vizsgálata}

A filogenetikai vizsgálatot az általunk meghatározott 13 NBS RGA és 311 nemzetközi adatbázisból származó NBS szekvencia (293 a Rosaceae családból és 21 nem Rosaceae családból származó) illesztése, és ebből készített filogenetikai törzsfa alapján végeztük el (2. melléklet). A dendrogramon két (CC NBS és TIR NBS) jól elkülönülő csoportba kerültek a szekvenciák.

A saját NBS LRR szekvenciáink négy távoli csoportban helyezkednek el a törzsfán. A PaCC 5 és PaCC 2 a korábban Samuelian és mts. (2008) által létrehozott csoportok szerint a non-TIR I, a PaCC 1, 3, 4, 6, 7, 8, 9, 10 és 11 non-TIR VI csoportba sorolódtak. 
A kajszi TIR szekvenciái közül a PaT 1 a TIR XII és a PaT 2 a TIR XI csoportba került. A filogenetikai törzsfán a 70 \%-nál nagyobb bootstrap értékkel támogatott elágazásokat fogadtuk el eltérő csoportnak.

A törzsfán kétféle csoport kialakulását figyeltük meg. Az első típusú csoportokban egy nemzetségből származó szekvenciák, míg a második típusú csoportban több génuszből származó szekvenciák kerültek. A CC-NBS szekvenciák $91 \%$-a rendeződött több nemzetségből származó szekvenciákat tartalmazó csoportokba. A TIR szekvenciák esetében ez az érték $57 \%$ volt. A törzsfán a TIR-NBS-LRR szekvenciákat tartalmazó csoportban a nem Rosaceae családból származó szekvenciák külcsoportokat alkottak a Rosaceae eredetű szekvenciáktól. A CC típusú csoportban viszont a nem Rosaceae családba tartozó fajok szekvenciájának egynegyede a Rosaceae fajokkal került több nemzetséget tartalmazó csoportba. A dendrogramon a két csoport ágai eltérő hosszúságúak voltak. A TIR csoport szekvenciái terminális elhelyezkedéssel rövidebb ágakon, és fajilletve nemzetség specifikusan helyezkedtek el. A CC-NBS szekvenciák hosszabb ágakon helyezkedtek el, és az elágazások a fa alapi része felé tolódtak el. Ezen megállapítások alól két csoport a Prunus IV és Rosa IX. kivételt képzett.

\subsection{A 'Zard' és 'Orange Red' fajták vesszőfertőzésének transzkriptomikai vizsgálata cDNS-AFLP technikával}

A korábbi kísérleteink eredményei alapján megállapítható, hogy a 'Zard' fajta esetében tapasztalható ellenállóságot a vesszők háncsszövetének válaszreakciója biztosítja. A háncsszövetekben bekövetkező génkifejeződés nyomon követésére a cDNS-AFLP ‘One gen one tag' (Vuylsteke és mts. 2007) technikáját választottuk. A technika biztosítja, hogy egyféle mRNS-ről egyetlen PCR termék keletkezzen, így növelve a vizsgálható expresszált gének számát. A két kiválasztott fajta közötti természetes fertőzéssel szembeni fogékonyságot a $\mathbf{2 7}$. ábra szemlélteti. 


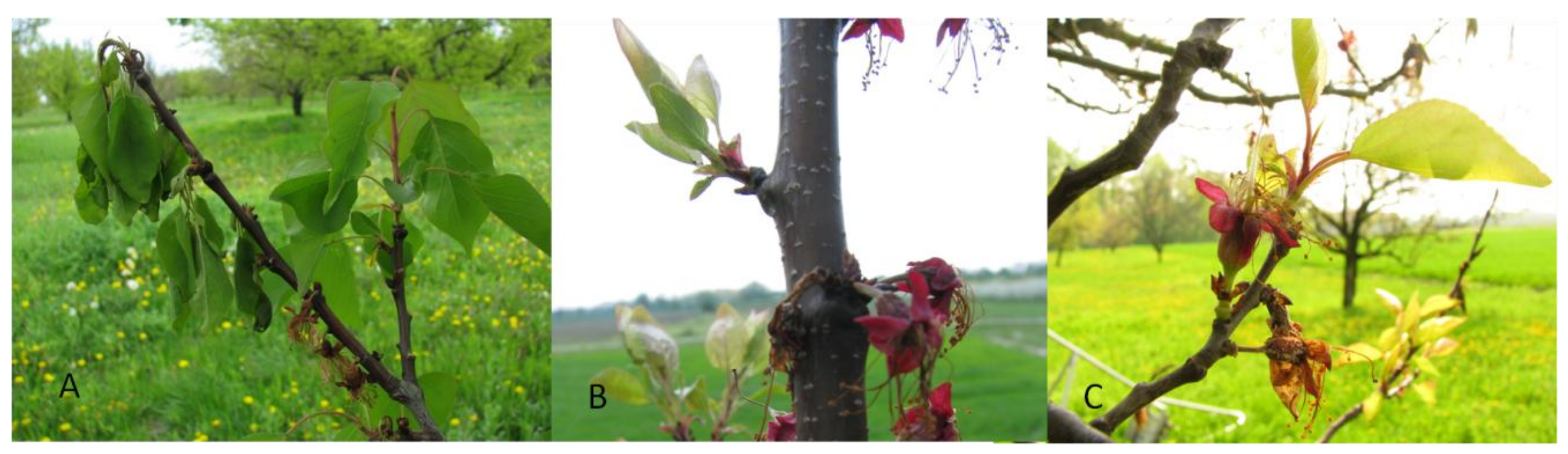

27. ábra. Az eltérő tünetek a $M$. laxa vesszőfertőzésére. A: 'Orange red’ fajta virágfertőzéséből kialakult teljes vesszőpusztulás. B: 'Zard' fajta termővesszőjén a virágfertőzést követően a kórokozó legfeljebb a kocsány körüli részen képes a háncsot elpusztítani, így a teljes termőrész épen marad C: A fertőzött és szürke exogén sztrómákkal borított virágról a kórokozó nem okozta a 'Zard' fajta rövid termőrész-pusztulását. 
A munka első fázisaként a vesszőkből RNS kivonására került sor. A kiválasztott kajszifajták egészséges és fertőzött hajtásainak a még nem fertőződött háncsszövetéből sikeresen izoláltunk RNS-t a forró bórsavas módszerrel Wan és Wilkins (1994) leírása alapján. A harminc mintából a 16 esetben sikerült 50 ng/ $\mu$ l-nél nagyobb koncentrációban a nukleinsav-kivonás. Ezek minőségét ellenőriztük agaróz gélen (28. ábra). A két rRNS alegység diszkrét sávjai alapján döntöttük el a RNS minta további alkalmazhatóságáról.

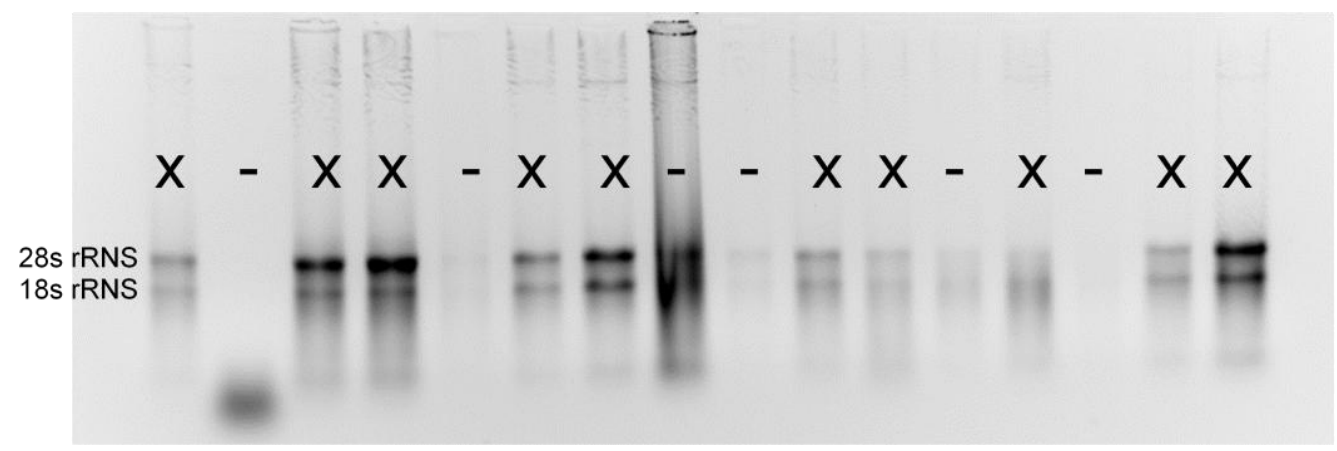

28. ábra. RNS kivonás ellenőrzése $1 \%$-os agaróz gélen. Az X-szel jelölt mintákat a két rRNS alegység diszkrét sávjai alapján választottuk ki további vizsgálatokra.

A cDNS kiegészítő szál készítésénél eltértem a protokolltól, mert a második szál szintézisét követően nem alkalmaztuk az E. coli ligázt. Elökísérletben ugyanazt a mintát kétféleképpen (ligázzal és nélküle) elkészítettük és azonos mintázatot kaptuk az akrilamid gélelektroforézis során.

A cDNS-AFLP első, nem szelektív PCR reakció agaróz gélen történő elválasztása során a protokoll által megadott 100-500 bp közötti elmosódott DNS mintázatot kaptuk.

A második, szelektív nukleotidokat alkalmazó PCR reakció eredményét az 29. ábra gélképe mutatja be.

$\mathrm{Az}$ agaróz gélelektroforézis alapján sikeres reakciók termékeit nagy felbontású $8 \%$-os denaturáló akrilamid gélelektroforézissel választottuk el (30. ábra). A gélen azokat a transzkriptum eredetü DNS fragmentumokat (TDF) választottuk ki szekvencia meghatározás céljából, amelyek egyedien jelentek meg a két fajta fertőzött mintái között. 30 fragmentumot izoláltunk, és ezekből 18 mintát sikerült felsokszorosítanunk re-PCR során. A PCR termékek bázissorrendjét direkt szekvenálással határoztattuk meg. 


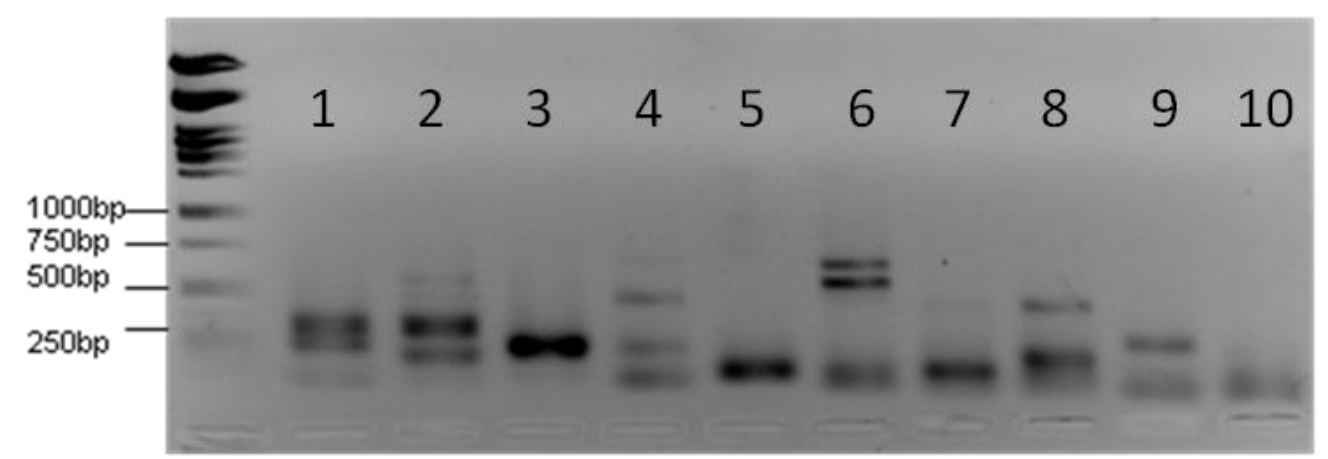

29. ábra A II. szelektív primerkombináció alkalmazása a 10 vizsgált kajszimintán. Minták sorrendben (Z: 'Zard', OR: 'Orange Red') 1: Z egészséges II., 2: OR egészséges I., 3: $Z$ egészséges II., 4: Z fertőzött II., 5: Z fertőzött II., 6: Z fertőzött I., 7: Z fertőzött I., 8: OR fertőzött I., 9: Z fertőzött I., 10: Z egészséges M: 1-kb + DNSmarker

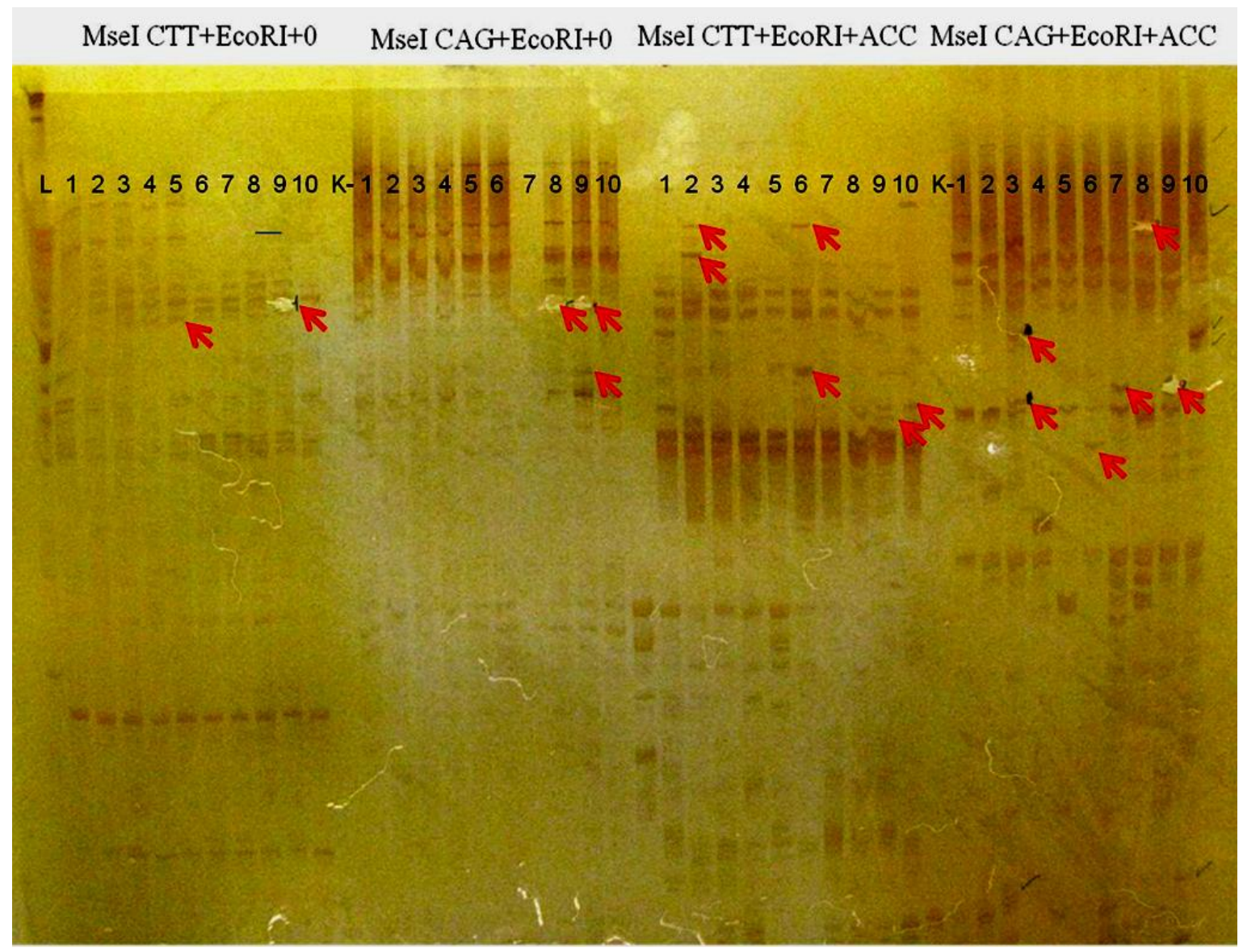

30. ábra. A kajszivesszők háncsszövetmintáinak cDNS-AFLP vizsgálata négy primerkombinációt alkalmazva. Z: 'Zard' OR: 'Orange Red' 1: Z egészséges II., 2: OR egészséges I., 3: Z egészséges II., 4: Z fertőzött II., 5: Z fertőzött II., 6: Z fertőzött I., 7: Z fertőzött I., 8: OR fertőzött I., 9: Z fertőzött I., 10: Z egészséges K-: vizes kontroll A piros nyilak jelzik a gélből kivágott és megszekvenáltatott fragmentumok egy részét. 


\subsubsection{A TDF-ek homológia alapján történő azonosítása}

Az NCBI nukleotid adatbázisában (nBLAST) és az őszibarack genomon (Phytozome 8.v) azonosítottuk a 18 mintánkkal nagy hasonlóságot mutató szekvenciákat (13. táblázat).

Egy fertőzött vesszőből származó ‘Orange red’ szekvenciáról megállapítottuk, hogy a Pseudomonas fluorescens szaprofág baktérium génjét kódolja, ami külső szennyeződésre utalt. A további elemzésekböl ezt a szekvenciát kizártuk. A 17 szekvencia őszibarackgenommal történő illesztés során 11 esetben sikeresen határoztuk meg a genomban való elhelyezkedésüket (13. táblázat). A 3., 6., 9., 11., 14. és 18. minta esetében nem sikerült az őszibarackgenommal értékelhető azonosságot kimutatnunk ( $E$-érték $<10^{-8}$ ). A 11 szekvencia feltételezhető funkciójának megállapítását homológia alapján végeztük el. Három minta esetében $(4 ., 10 ., 16$.) nem találtunk lehetséges génfunkciót. A 12. és 13. TDF-ek mindkét fajtában megjelentek a fertőzés hatására, és egy cink-ujj domént tartalmazó fehérjét kódolnak.

A 15. TDF szekvenciája a poligalakturonáz enzimgátlófehérjék (PGIP) szekvenciáival mutatott egyezést (E-érték: 0). A szekvencia forrását jelentő TDF kizárólag a poliakrilamid gélen az első alkalommal gyüjtött, fertőzött 'Zard' mintákban volt megtalálható. Továbbiakban ennek a PGIP gén szekvenciájának meghatározását és a vesszőmintákban a gén kifejeződésének vizsgálatát tüztük ki célul. 
13. táblázat. A cDNS-AFLP során kiválasztott fragmentumok lehetséges génfunkcióinak feltételezése szekvenciaazonosság alapján. A táblázatban az őszibarackgenommal hasonlóságot $\left(E\right.$-érték $\left.<10^{-8}\right)$ mutató fertőzött mintákból származó szekvenciákat tüntettük fel. Zöld színnel a 'Zard' fajtából, narancssárga háttérrel az 'Orange red' fajtából, míg a mindkét fajta mintáiban jelenlévő fragmentumokat türkizkékkel jelöltük.

\begin{tabular}{|c|c|c|c|c|c|}
\hline \multirow{2}{*}{$\begin{array}{l}\text { Transzkriptumból } \\
\text { származó DNS } \\
\text { fragmentum (TDF) }\end{array}$} & \multirow{2}{*}{$\begin{array}{l}\text { TDF hossza } \\
\text { (bp) }\end{array}$} & \multirow{2}{*}{ Azonosság alapján feltételezhető fehérjék } & \multicolumn{3}{|c|}{ Az őszibarack genomjával történő illesztés alapján } \\
\hline & & & TDF lókusza, & $E$-értéke, & kromoszómán a pozíciója \\
\hline \multirow[b]{2}{*}{ 1. Zard fertözött I. } & \multirow[b]{2}{*}{363} & \multirow[b]{2}{*}{ PQ-loop fehérjecsalád } & ppa017921 & $2 \mathrm{e}-63$ & 3: 21.079.579-21.081.198 \\
\hline & & & ppa021350, & $2 \mathrm{e}-63$ & 3: 21.076.300-21.089.160 \\
\hline 2. Zard fertőzött I. & 538 & Della protein & ppa003975 & $1.00 \mathrm{e}-254$ & 7: 20.910.516-20.912.871 \\
\hline 4. Orange Red fertőzött I. & 733 & ismeretlen fehérje & ppa011164 & $1.5 \mathrm{e}-124$ & 2: $3.192 .907-3.195 .390$ \\
\hline 7. Zard fertőzött II. & 605 & Foszforibulokináz & ppa000994 & $2.6 \mathrm{e}-133$ & $1: 22.024 .771-22.025 .550$ \\
\hline 8. Orange Red fertőzött I. & 224 & Transzmembrán aminosav transzport fehérje & ppa005008 & $6.6 \mathrm{e}-89$ & 4: $24.765 .300-24.785 .103$ \\
\hline 10. Zard fertőzött I. & 185 & ismeretlen fehérje & & $3.8 \mathrm{e}-61$ & 6: 11.623.135-11.623.296 \\
\hline 12. Zard fertőzött I. & 125 & Cink-ujj fehérje (C3HC4) & ppa024723 & $8 \mathrm{e}-36$ & 2: $25.878 .109-25.880 .378$ \\
\hline 13. Orange red fertőzött I. & 124 & Cink-ujj fehérje (C3HC4) & ppa024723 & $8 \mathrm{e}-36$ & 2: $25.878 .109-25.880 .378$ \\
\hline \multirow{2}{*}{ 15. Zard fertőzött I. } & \multirow{2}{*}{452} & \multirow{2}{*}{ Poligalakturonáz-gátló fehérje (PGIP) } & ppa008474 & $5.5 \mathrm{e}-153$ & 7: 10.624.791-10.625.217 \\
\hline & & & ppa008479 & 0. & 7:10.645.144-10.645.571 \\
\hline 16. Orange Red fertőzött I. & 289 & ismeretlen fehérje & ppa007057 & $1 \mathrm{e}-24$ & 6:14.564.060-14.564.360 \\
\hline 17. Zard fertőzött II. & 380 & PQ-loop fehérje család & ppa021350 & $2 \mathrm{e}-63$ & 3: 21.076.300-21.089.160 \\
\hline
\end{tabular}




\subsubsection{PGIP gének szekvenciáinak meghatározása}

Azonosítottunk az általunk megtalált PGIP gén részleges szekvenciájával hasonlóságot mutató két lókuszon található két PGIP ortológ gént az őszibarack és két gént az almagenomból és szekvenciájukat letöltöttük. Az ezekkel nagy hasonlóságot mutató Rosaceae családhoz tartozó fajokban található feltételezhető PGIP szekvenciákat az NCBI adatbázisból gyüjtöttük ki. A szekvenciákból a nem kódoló részeket eltávolítottuk (intronok, 3' és 5' UTR) és ezek illesztése alapján a konszenzus szekvenciarészekre primereket terveztünk az egymástól legtávolabb eső 3' és 5' konzervált régiókra (31. ábra). A forward primerek közül a PGIP1 F, a Prunus nemzetség szekvenciájára specifikusan, PGIP2 F primert Prunus, Malus és Pyrus nemzetségek konszenzus szekvenciájára terveztük. A reverse primerek közül az egyiket a 15. TDF minta szekvenciájára specifikusan (PGIPZ R), míg a másodikat (PGIP R), a 15. TDF mintát mellőző szekvenciákra terveztük. A primerek alkalmazásának optimalizálására gradiens PCR-t készítettünk mindkét fajta genomi DNS-én (32. ábra és 33. ábra). A PGIP1F és PGIPZ R primerkombináció alkalmazásakor mindkét fajta esetében egy 750bp körüli termék jelent meg a legmagasabb $\left(60,9{ }^{\circ} \mathrm{C}\right)$ tapadási hőmérséklet alkalmazásakor, ez alapján megállapíthatjuk, hogy a PGIPZ R primer nem működik specifikusan a Zard fertőzött mintáiban kimutatott PGIP allélra. 


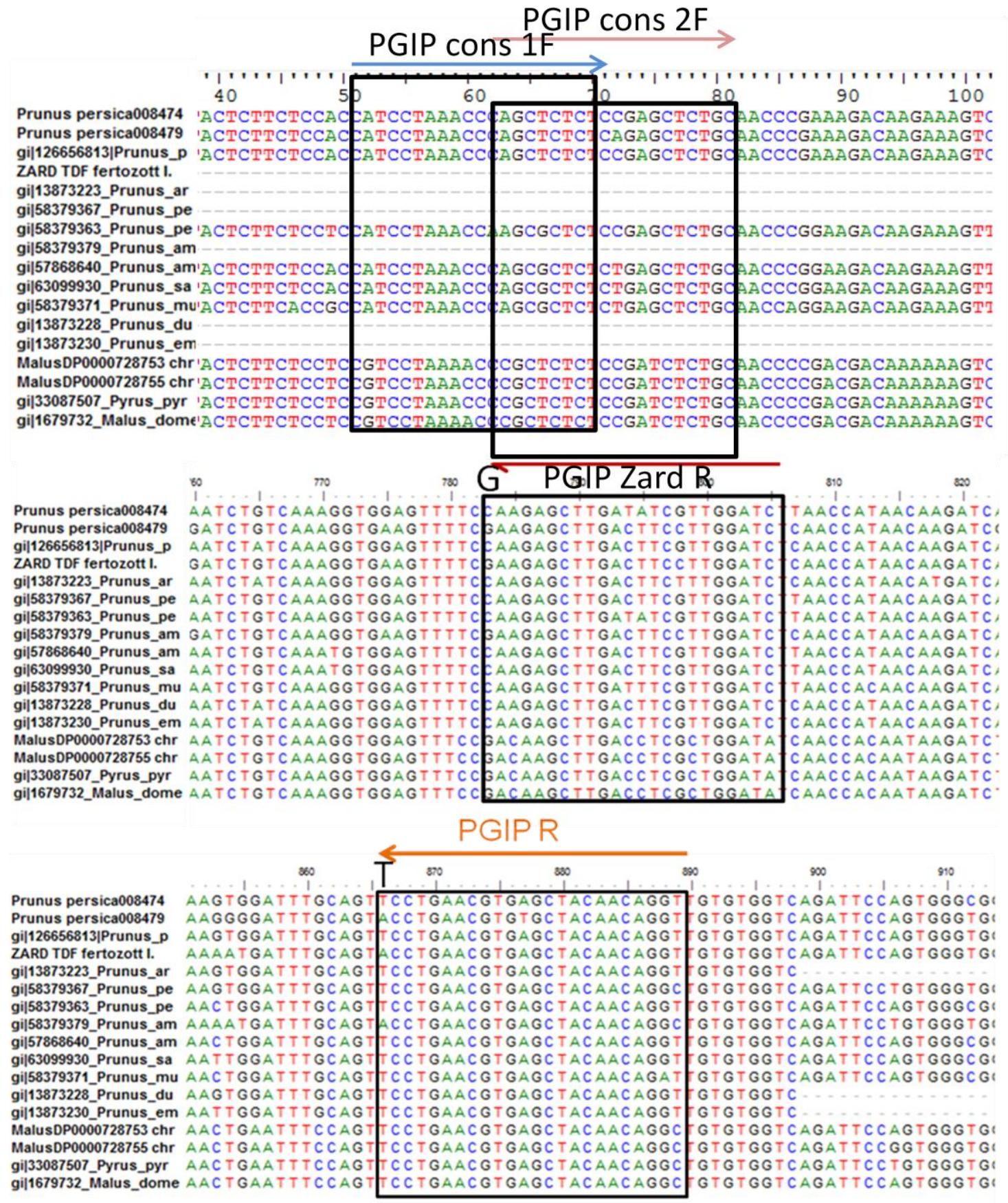

31. ábra. A négy primer elhelyezkedése a Rosaceae PGIP génszekvenciák illesztése alapján kapott konzervált régiókra. A PGIP Zard R reverz primert a 15. TDF szekvenciára specifikusan (G), míg a PGIP R primer a 15. TDF felszaporítását mellőzi (T). 


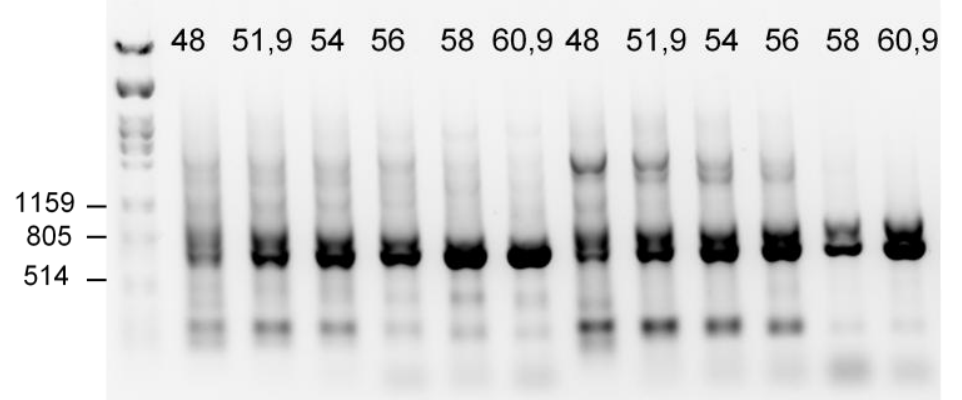

32. ábra. A PGIP1F és PGIPZ R primer kombináció gradiens PCR alkalmazása 48-60,9 Cos tapadási hőmérsékletek alkalmazásával a Zard (1-6 oszlop) és Orange Red (712 oszlop) fajták DNS-ével.

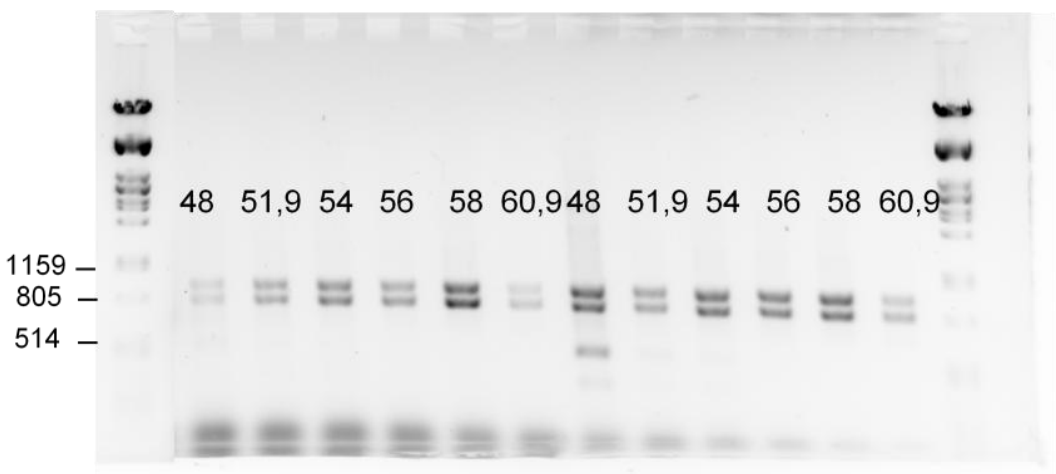

33. ábra. A PGIP1F és PGIPR primerkombináció gradiens PCR alkalmazása 48-60,9 C-os tapadási hőmérsékletek alkalmazásával a 'Zard' (1-6 oszlop) és 'Orange Red' (712 oszlop) fajtákon.

A 15. TDF minta szekvenciáját kizáró primerkombináció (PGIP1F és PGIP R) gradiens PCR eredményéül két jól elkülönülő 800 bp és 900 bp hosszúság körüli fragmentumokat kaptunk, a két fajta között hosszpolimorfizmust nem tapasztaltunk. A becsült fragmenthosszak megfeleltek az őszibarackgenomból származó két lókuszon található intron nélküli és intront tartalmazó allélok hosszúságának (33. ábra).

A két primerkombinációval ellenőriztük a vesszőmintáinkból származó cDNS-eket, hogy jelen van-e a PGIP gén bármely allélja. A fertőzetlen mintákban nem kaptunk terméket a PGIPR és PGIP1F primerek alkalmazásával $(1,8,9)$. A két fajta fertőzött mintáiban $(2,3)$ viszont azonos erősségü mintázatot kaptunk. A második alkalommal gyüjtött 'Zard' fertőzött mintákban (4 és 6) egy hosszabb és gyengébb termék jelent meg (34. ábra). Megállapíthatjuk tehát, hogy a PGIP gének a két kajszifajta esetében a M. laxa fertőzésre adott válaszként fejeződnek ki a vessző háncs szövetében. 


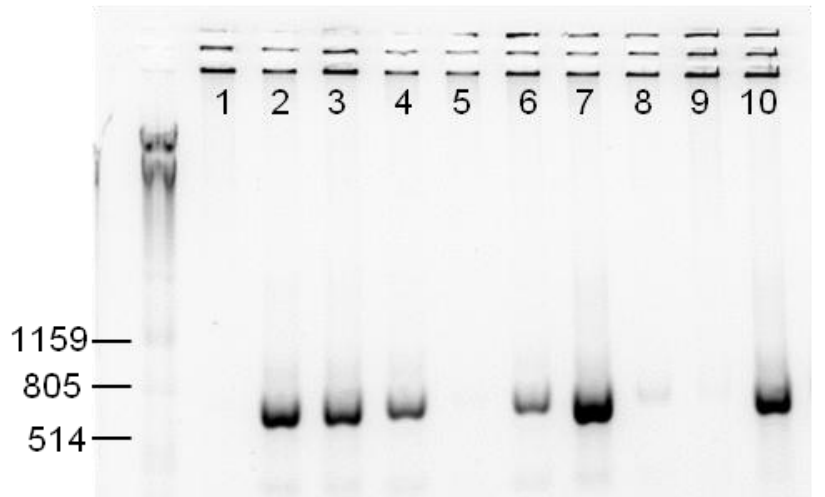

34. ábra. A vesszőkből származó cDNS-minták PGIP1 F és PGIP R primerekkel készült PCR-termékek elválasztása agarózgélen. 1: Z ép., 2: Z fertőzött I., 3: OR fertőzött I., 4: Z fertözött II., 5: Z fertőzött II., 6: Z fertőzött II., 7: Z fertőzött I., 8: Z ép II., 9: OR ép , 10: Z fertőzött I. Rövidítések Z: 'Zard', OR: 'Orange Red'

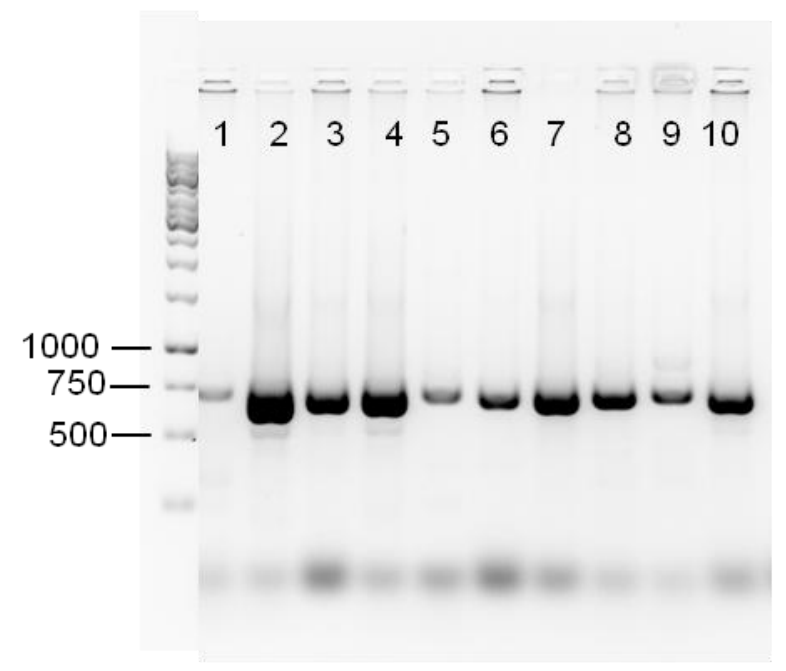

35. ábra. A vesszőkből származó cDNS-minták PGIP1F és PGIPZ R primerekkel készült PCR-termékek elválasztása agarózgélen. Minták sorrendben 1: Z ép II., 2: Z fertőzött I., 3: OR fertőzött I., 4: Z fertőzött II., 5: Z fertőzött II., 6: Z fertőzött II., 7: Z fertőzött I., 8: Z ép II., 9: OR ép , 10: Z fertőzött I. Rövidítések Z: 'Zard' OR: 'Orange Red'.

A PGIPZ R és PGIP1F primer kombináció alkalmazásakor a fertőzött 'Orange Red' mintákban is megjelent azonos erőségű termék (35. ábra), miközben a fertőzetlen mintákban egy halvány fragmentum jelentkezett. Ezek alapján a cDNS AFLP során kiválasztott PGIP szekvenciára (15. TDF) tervezett primer (PGIPZ R) nem müködik allélspecifikusan, mert mindkét fajta fertőzetlen és fertőzött mintáiból származó cDNS-en fragementumokat szaporított fel. 
A PCR-termékeink szekvenciájának meghatározásával kívántuk ellenőrizni, hogy a felszaporított termékek valóban a PGIP génekkel mutatnak hasonlóságot. Ezentúl a cDNSAFLP technika alkalmazásakor kizárólag a 'Zard' I. fertőzött mintáiban megjelenő (15. TDF) allél szekvenciáját szerettük volna meghatározni.

Három fajta genomi DNS-én ('Korai zamatos', 'Orange red', 'Zard') és a két fajta fertőzött vesszőiből készült cDNS mintáján készítettünk PCR-t PGIP1 F és PGIP R primereket alkalmazva. A gélből izolált és klónozott fragmentumokat 33. ábra mutatja meg. A második $2 \%$-os agaróz gélen a 900 bp hosszúságú termékről kiderült, hogy két eltérő hosszúságú fragmentumot rejt (36. ábra).
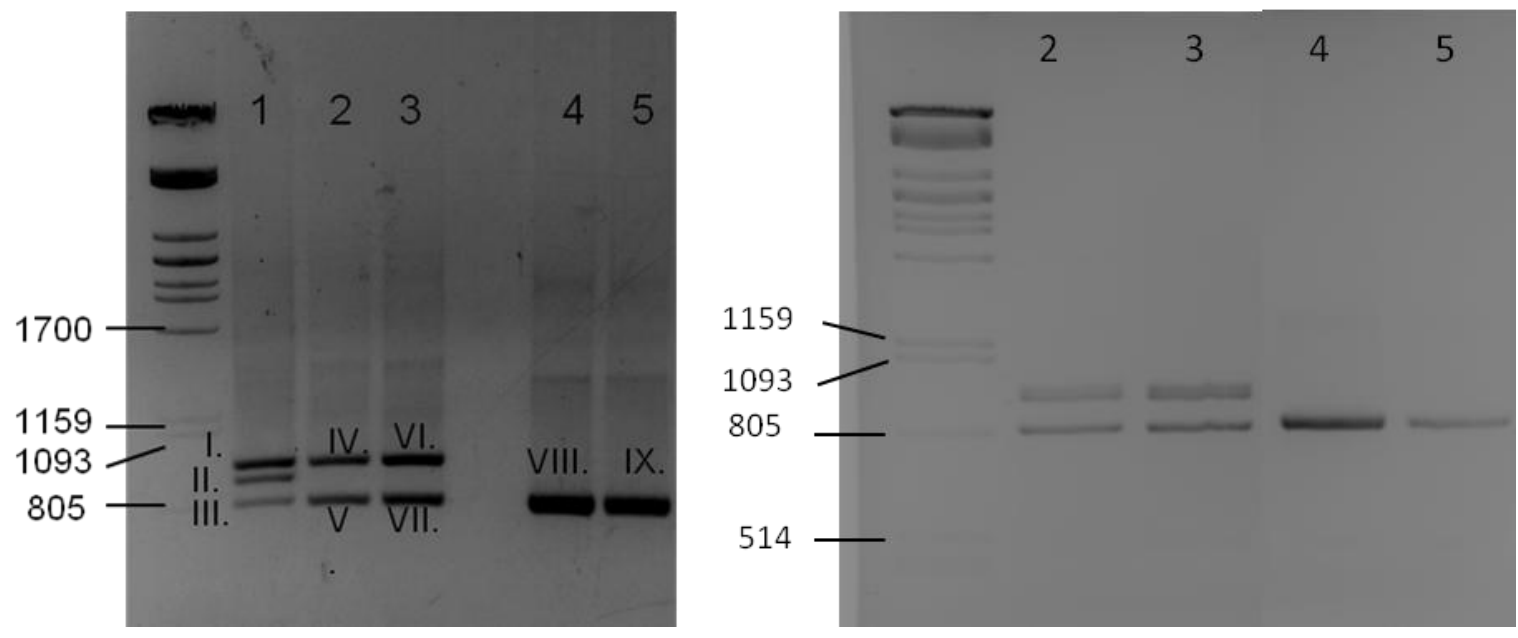

36. ábra. PGIP1 F és PGIP R primerkombinációval készült PCR-termékek elválasztása 1 és $2 \%$-os agaróz gélen. 1: 'Korai zamatos', 2: 'Orange red', 3: 'Zard', 4: cDNS Zard fertőzött I., 5: cDNS 'Orange red' fertőzött vessző minta. A római számokkal jelöltem a gélből izolált és klónozott fragmentumokat.

A gélből kivágott fragmentumokat klónoztuk, és a genomi fragmentumonként (IVII) 5- klónt, míg a cDNS-ről (VIII-IX) készült klónokból 10-et küldtünk el szekvenciameghatározásra. Egy fajtából összesen négy lehetséges allélt a 'Zard' fajtából sikerült azonosítanunk, míg az 'Orange red' és 'Korai zamatos' fajtából 3-3 allélt azonosítottunk. A 'Zard' fajtából két szekvencia tartalmazott azonos hosszúságú intront viszont a 36. ábrán bemutatott gélképén hosszabb (900bp) allélok (IV: és VI. fragmentumok) két eltérő méretű fragmentumból állnak. Így a 'Zard' fajta genomi alléljainak a száma legalább öt, amire elfogadható magyarázat lehet a megszekvenált és eltérő allélként kezelt szekvenciák között az eltérés nem minden esetben valós, vagy a kajszi esetében több mint két kópiában 
található meg a PGIP lókusz. A két fajta és a cDNS termékekről készült szekvenciák egyike sem volt azonos az eredeti cDNS AFLP során kapott 15. TDF számú minta szekvenciájával.

A genomi szekvenciák közül a 'Zard' és az 'Orange red' fajta esetében két különböző hosszúságú szekvenciát kaptunk, a 988 bp hosszú termék tartalmazott 147 bp hosszúságú II. fázisú intront, míg a 841 bp hosszúságú termék egy nyílt leolvasási keretet adott. A 'Korai zamatos' fajta esetében a gélböl kivágott I. számú fragment méretében megegyezett a két másik fajta 988 bp hosszúságú termékével, II. termék kolóniáiból származó szekvencia egy 83 bp hosszúságú kettes fázisú intront tartalmazott. Ez az intron az őszibarackgenomból származó PGIP gén intronjához képest egy nukleotiddal volt hosszabb. A két cDNS (fertőzött 'Zard I.' és fertőzött 'Orange red') mintáról származó szekvenciák hossza egységesen 841 bp hosszúságú volt.

A két cDNS-ből származó minta esetében 10-10 megszekvenált plazmidról az 'Orange red' esetében hat eltérő szekvenciát azonosítottunk, a 'Zard' esetében öt eltérö nukleinsav-szekvenciájú allélt találtunk. A alma és őszibarck genomban kép kópiában találhatók meg a a PGIP lókuszok, ezért maximálisan négy allélt vártunk. Mindkét cDNSből származó szekvenciák esetében ennél többet kaptunk, ezért a szekvenciákat a kromatogrammon ismét ellenöriztük. Az eltérést mutató pozíciókban nem tudtuk a kromatogrammok revíziója után sem ezekből a szekvenciákról eldönteni vajon azonos allélt kódolnak-e. Az eltérések a reverz transzkripció és azt követő PCR során is kialakulhattak. Az eltérést mutató nukelotidok ellenőrzése végett szekvencia adatbázisból származó szekvenciák és a saját szekvenciák illesztése alapján megállapítható, hogy a kérdéses pozíciók mindegyikében több eltérő nukleotid található.

A cDNS-minták PCR analízise alapján megállapítható, hogy a fogékony fajtában egyaránt megjelentek a fertőzés hatására a PGIP gén szekvenciái, habár az expresszió szintjére nem tudtunk következtetni. Eszerint a cDNS AFLP során tapasztalt eltérést, miszerint a 15. TDF csak a 'Zard' fertőzött I. mintákban jelent meg, a PGIP allélok közötti szekvencia eltérés okozta és nem az expressziós különbség. Az AFLP során alkalmazott restrikciós enzimek közül csak a Tru I hasító helyét sikerült a PGIP szekvenciákon megtalálnunk, mert a megszekvenált klónok nem tartalmazták a 15. TDF 3' részét, ahol az Eco RI hasítása történt. Az adatbázisból kigyüjtött teljes PGIP szekvenciák egyikén sem találtuk meg az Eco RI hasító helyet ezért valószínüsíthetjük, hogy a 15. TDF szekvenciája ezen a részen tér el az 'Orange red' és a többi Prunus PGIP szekvenciától. 
A genomi és kifejeződő kajszi PGIP gének szekvenciájának illesztését elvégeztük. Az illesztésbe bevontuk az összes NCBI adatbázisból található Prunus PGIP génszekvenciát és az összes általunk meghatározott eltérő PGIP nukleotidszekvenciát. A filogenetikai törzsfa alapján megállapítható, hogy a legnagyobb hasonlóságot a 15. TDF szekvenciával P. americana (gi 58379371) fajból származó és a 'Korai zamatos' (9pFR-KZ_II_1) kajszifajtából származó rövid intront tartalmazó allél szekvenciák adták (37. ábra). Mivel a 'Korai zamatos' fajta az M. laxa fertőzéssel szemben fogékony, így 15. TDF és a 'Korai zamatos' szekvencia közötti aminosav-eltéréseket kerestem meg az illesztés alapján. Összesen öt különböző aminosav található a két szekvencia között (38. ábra). Az aminosav helyettesítések a 'Korai zamatos' és a 'Zard' fajta szekvenciái között neutrálisnak az aszpargin és aszparginsav $(\mathrm{N} \leftrightarrow \mathrm{D})$ csere számít, a további blossom mátrix alapján nem konzervatív változások $(\mathrm{V} \leftrightarrow \mathrm{F}, \mathrm{P} \leftrightarrow \mathrm{S}, \mathrm{D} \leftrightarrow \mathrm{A}, \mathrm{T} \leftrightarrow \mathrm{K})$ a fehérje funkciójának megváltozását okozhatják. Az öt eltérő pozícióban a 'Korai zamatos' fajta szekvenciája négy esetben azonos az őszibarack ppa008479 lókuszon található alléljával. A 15 TDF szekvencia a PGIP génnek mindössze $30 \%$-át fedi le, így a teljes allél szekvenciájának meghatározása elengedhetetlent a szekvenciák összehasonlításához. 


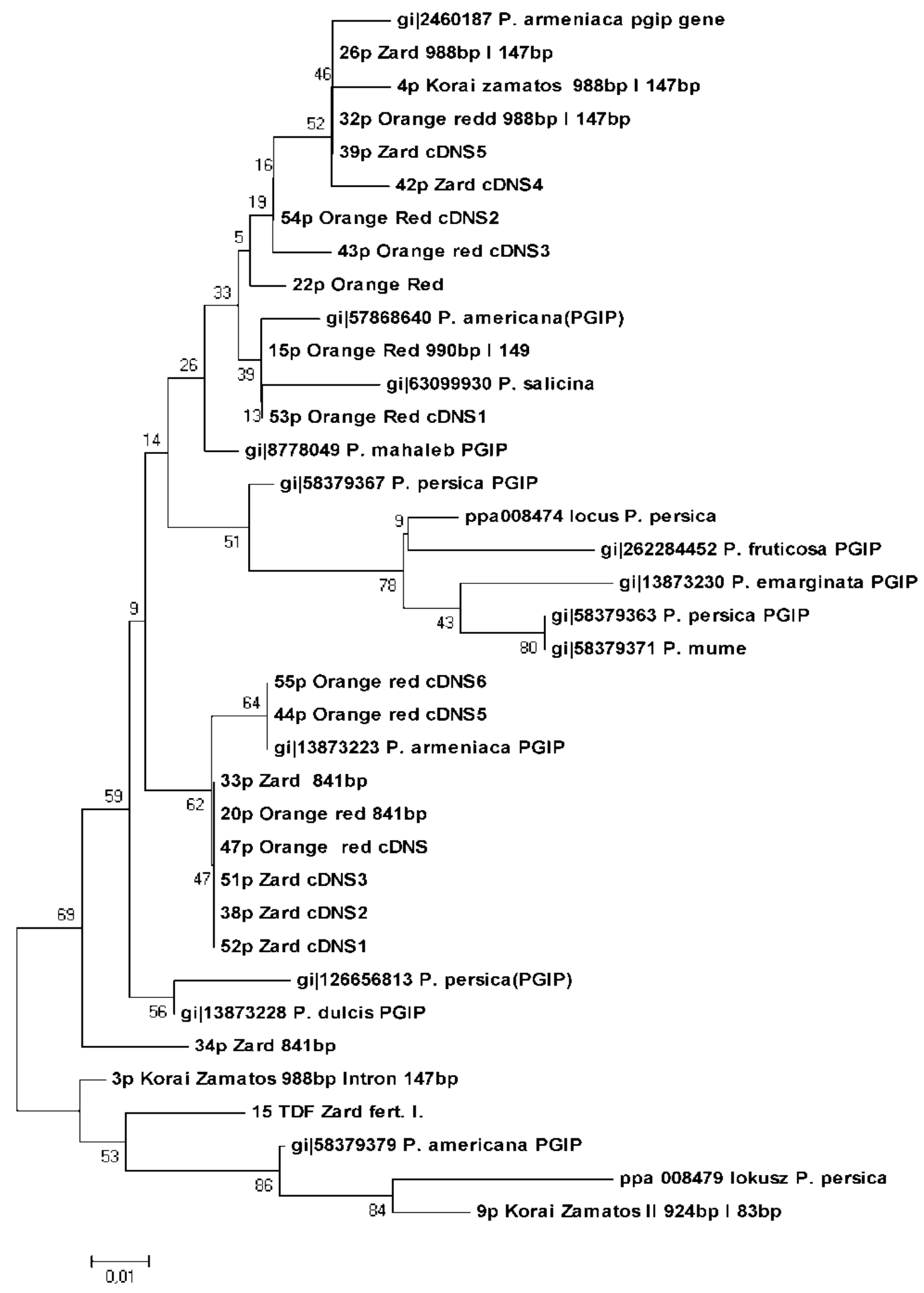

37. ábra. A Prunus fajokból származó PGIP gének következtetett aminosav szekvenciái szomszéd összevonás eljárással szerkesztett filogenetikai törzsfája. Az általunk meghatározott szekvenciákat számokkal jelöltük. A genomi szekvenciáink mögött az allélok hosszát és az intronok méretét jelöltük. Az adatbázisból származó szekvenciák a gén index és a faj latin nevével kerültek feltüntetésre. 


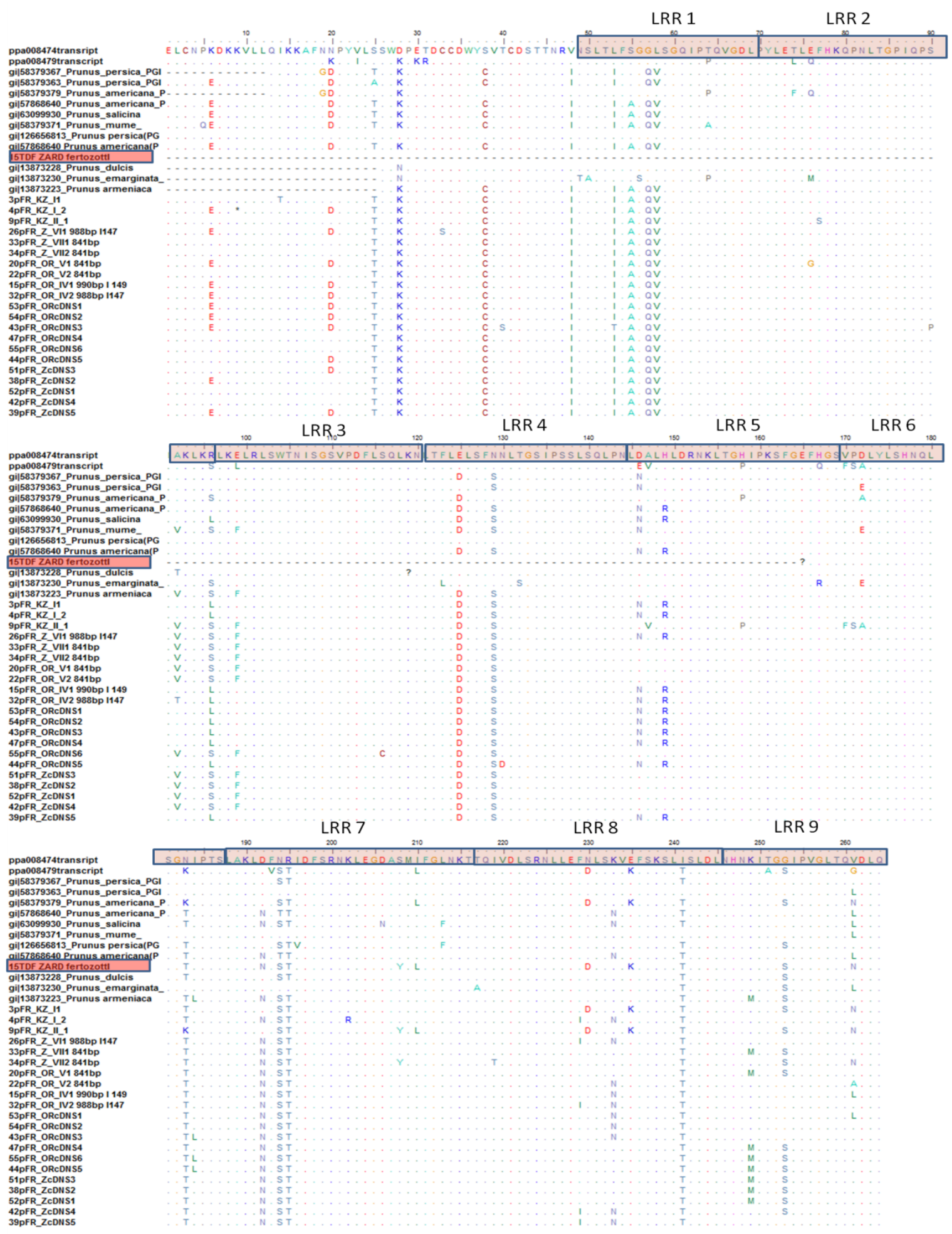

38. ábra. Prunus fajok részleges PGIP génjének cDNS származtatott aminosav sorrendjének ClustalW szoftverrel késztett többszörös illesztése. A PGIP gén LRR ismétlődéseit kék kerettel jelöltük. A cDNS AFLP során meghatározott 15. TDF piros árnyalással tüntettük fel, rövidítések OR: 'Orange red', Z: 'Zard', KZ: 'Korai zamatos'. 


\section{EREDMÉNYEK MEGVITATÁSA}

\subsection{Kajszifajták és közeli rokon diploid Prunus fajok fogékonysága a $M$. laxa okozta termőrészpusztulásra}

A vizsgált fajok és fajták esetében tapasztalt termőrészpusztulás mértéke alapján megállapítható, hogy a kajszifajták érzékenysége folyamatos eloszlást mutatott. Az átlagos termőrészpusztulás a vizsgált kajszifajták esetében 5-30 \% között változott. A kajszifajták ellenállóságát ez alapján, mennyiségi tulajdonságként lehet jellemezni, ami alól a 'Zard' fajta ellenállóképessége képez kivételt. Az adataink összevetése irodalmi adatokkal nem történhet egzakt módon, mert korábban nem történt a kórokozó kártételének idős fajtagyüjteményben felmérése az általunk használt kategóriák alkalmazásával. Erre magyarázatot ad, hogy a $M$. laxa kártétele az ültetvény vagy génbank gyors visszafordíthatatlan leromlását okozza. A fertőzés felvételezésére korábban több módszert is alkalmaztak. Benedek és mts. (1990) az összes fertözött termőrész arányát százalékosan adta meg. Komar-Tyomnaya és Richter (2000) ötfokozatú érzékenységi csoportokba sorolta a vizsgált fajtákat, de a csoportosítás szempontjait nem közölték. Balan és mts. (1999) a fertőzés gyakoriságát és a fertőzés intenzitását felvételezték és ezen értékek szorzatával határozták meg a fertőzési szintet (Attack level:A.L).

A meggy esetében Rozsnyay (2001) arról számol be, hogy a virágfertőzés mindegyik vizsgált fajtán legalább $40 \%$-os mértékben előfordult, de az immunisnak tartott 'Bosnyák’ és ‘Csengődi' fajtákon nem következett be vesszőpusztulás. Ezzel megegyező következtetésre jutottunk a kajszi fajták esetében, mert az ellenálló 'Zard' fajta esetében a virágfertőzés előfordult, míg termőrészpusztulás csak nagyon ritkán.

Egy kecskeméti kajsziültetvényben nyolc magyar fajta egy éves moniliás vesszőfertőzés megfigyelése alapján Benedek és mts. (1990) 9-28 \% közötti fertőzöttséget rögzítettek. A vizsgált két ültetvényrész között a 'Gönci magyarkajszi' és 'Ceglédi óriás' fajták esetében több mint $10 \%$-os eltérést tapasztaltak. A két ültetvényrészben felvételezett fertőzés alapján a 'Mandulakajszi' (12 és $14 \%$ ) és 'Ceglédi bíborkajszi' (14 és $9 \%$ ) adatai vethetőek össze az általunk mért ellenállósággal. A szigetcsépi ültetvényben felvételezett fertőzöttség alapján felállított érzékenységi sorban a fenti két fajta egymás mellett található 16 és $17 \%$-os fertőzöttséggel. Amennyiben Benedek és mts. (1990) adataiból a 'Ceglédi óriás' (10\%) és 'Gönci magyarkajszi' (11\%) esetében kizárólag az I. ismétlés adatait tekintjük, az érzékenységi sorunkkal összevetve megállapítható, hogy a 'Ceglédi óriás' 
$3 \%$-kal erősebb fertőzést szenvedett a szigetcsépi felmérés során, viszont a 'Gönci magyarkajszi' esetében 3\%-kal nagyobb ellenállóságot tapasztaltunk. Az általunk mért erősebb fertőzöttséget a 'Mandulakajszi’, ‘Ceglédi óriás', ‘Ceglédi bíborkajszi’ esetében az extenzív ültetvényi körülményekkel, míg a csökkent fogékonyságot 'Gönci magyarkajszi' esetében a felhagyott ültetvényben a 'Gönci magyarkajszi' alacsony virágszámával magyarázhatjuk.

Balan és mts. (1999) vizsgálataiban 124 kajszifajta és hibrid közül egyetlen hibridet találtak teljesen ellenállónak, 4 fajtát ellenállónak vagy mérsékelten ellenállónak, 14 fajtát fogékony és nagyon fogékony kategóriába sorolnak. A 'Goldrich' fajtát a fogékony kategóriába sorolták, ami az általunk mért közel $20 \%$-os termőrész pusztulással megegyező eredménynek tekinthető.

Komar-Tyomnaya és Richter (2000) a nyikitai csonthéjas génbanki gyüjteményben végzett vizsgálatai alapján a kajszifajtákat egységesen a fogékony kategóriába sorolták. A 'Sintez' és 'Uryuko-alyca' kajszi és cseresznyeszilva hibridfajták teljes immunitást mutattak a fertőzésre. A $P$. dasycarpa fajták közül 'Grossa tardiva', 'Manaresi' 'Tlor Ciran', 'Picole precocte', a plumcot fajták közül a 'Zamshevy', 'Krasny’ fajtákat sorolták az ellenálló kategóriába. A P. sibirica faj egyedeit a fogékony kategóriába sorolták, ami a Vácrátóti Botanikus Kertben szibériai kajszikon tapasztalt erős természetes monilia fertőzéssel megegyezik. Tzonev és Yamaguchi (1999) a 'Red June' és a 'Sordum' $P$. salicina fajtákat határozták meg teljesen ellenállónak. A saját eredményeink szerint a két vizsgált japánszilvafajta a 'Methley ' és 'Burbank' teljes immunitást mutatott a három vizsgálati év során. Az 1/33 kajszi és cseresznyeszilva hibrid ellenállósága is megfelel Komar-Tyomnaya és Richter (2000) eredményeinek. Fontos megemlíteni, hogy a $P$. dasycarpa Surányi (2003) szerint a $P$. armeniaca és $P$. cerasifera állandósult hibridje, így tulajdonképpen az 1/33 hibridünkkel pedigréje azonos. Természetesen ebben az esetben a rezisztencia forrása a $P$. cerasifera, amit az ültetvényünkben kijelölt mirabolán alanyon mért 2-3\%-os fertőzés erősít meg. A plumcot fajhibridek a kajszi és japánszilva keresztezésével létrehozott fajták, az ellenállóságot a japánszilva tulajdonságai közül örökölhették.

Tzonev és Yamaguchi (1999) a P. mume fajták ellenállóságáról számol be Japánban szerzett tapasztalataik alapján. A két év virágzási adatai szerint $P$. mume egyedek a botanikus kerti megfigyeléseink alapján teljes ellenállóságot mutattak. Két vizsgálati évben 
viszont a virágrügyek teljes téli fagykárt szenvedtek, így ezekben az években a kórokozó számára nem állt rendelkezésre fertőzési pont.

A mediterrán régióban ellenállónak tartott 'Hamidi','Ivone Liverani' (Nicotra és mts., 2006, Crossa-Raynaud, 1969) fajtákat a kísérleteink során nem vizsgáltuk, így ezek összehasonlítása az eredményeinkkel nem lehetséges.

Az érzékenységi sor alapján kétféle ellenállóságot tapasztaltunk. Az első esetben a termőrészpusztulás maximum 2-3\%-ot ért el. A P. salcina, P. cerasifera, $P$. dasycarpa, 1/33 kajszi-szilva hibrid és a $P$. armeniaca 'Zard' fajták rendelkeztek ezzel az ellenállósággal. Ezeken a fajtákon a virágfertőzés kialakulása után a termőrészek háncsszövetének néhány mm-es pusztulása ment végbe, amit a háncsszövet megvastagodása zárt le. $\mathrm{E}$ genotípusok esetében nem tapasztaltuk a hosszú termőrészek pusztulását a három év során, és az összes termőrészpusztulás nem érte el az $5 \%$-os szintet. A termőrészpusztulást általában a korona belső felében történt, árnyékolt gyenge növekedésű termőrészeken. A tünetek alapján ez az ellenállóság a fertőzés hatására alakul ki a háncsszövetben, ezért ezt a fertőzés hatására kialakuló aktív rezisztenciának tekintjük.

A kajszi fajták közül a 'Pisana', 'Pannónia', 'Venusz', 'Magyarkajszi C235', 'Gönci magyarkajszi', 'Nikitszkij' esetében a fertőzés nem érte el a $10 \%$-os termőrész pusztulást. E fajták esetében előfordult a hosszú termőrészek fertőződése, bár jellemzően mindegyik fajta rövid termőnyársakon hozta a virágait. Ez a jelenség az ellenállóság magyarázataként is szolgálhat, mert a rövid termőrészek pusztulása kisebb mértékü veszteséggel jár. A magyarkajszi fajtakörhöz tartozó 'Pannónia', 'Venusz', 'Magyarkajszi C235', 'Gönci magyarkajszi', 'Nikitszkij' fajták esetében a kis virágszám tovább csökkenti a fertőzés kialakulásának esélyét.

\subsection{A virágszirom fertőzésére adott reakciók összehasonlítása különböző fajtáknál}

A szirom fokozott fogékonyságára a mikroszkopikus vizsgálatok adtak magyarázatot. A keresztmetszeti felvétel alapján a szirmot összesen két összefüggő egysoros epidermisz sejtsor határolja, ami között egy nagy extracellulárisokat tartalmazó alapszövet található. Az epidermisz nem tartalmaz gázcserenyílásokat, a kórokozó enzimeivel képes a kutikula és a sejtfal áttörésére. Az epidermisz sejteket áttörve egy könnyen kolonizálható nagy intercellulárisokat tartalmazó mezofillum szövetet talál, ahol az extracelluláris 
sejtfalbontó enzimei szabadon terjedhetnek szét, így kialakítva a sziromszövet teljes macerációját.

Az ültetvényben megfigyelt virágfertőzés és a kasztrált virágok fertőződésének elmaradása alapján a kajszi, japánszilva és cseresznyeszilva mesterséges sziromfertőzését végeztük el. Az ültetvényben a fajták virágzásidejének eltéréséből adódó eltérő klimatikus viszonyok kiküszöbölése miatt tartottuk szükségesnek a fajták in vitro fertőzését.

A vizsgált kajszifajták szirmai a fertőzést követő 7 órában egységesen a fertőzési csepp körül mutatták a szövet pusztulását. A kajszifajták között 28 órával a fertőzés után tapasztaltunk a legnagyobb eltérést az elpusztult sziromlemez méretében. Ekkora az 'Orange red', 'Gönci magyarkajszi', 'Bergeron', 'Sulmonax', 'Korai zamatos', 'Forum' fajták szirmai teljesen elbarnultak, miközben a 'Marculesti 18/6' és 'Zard' fajták sziromfertőzése nem érte el a szirom felületének 50 \%-át. Habár ekkor (28 óra elteltével) jelentős eltérés volt tapasztalható a fajták között, 5 órával később mindegyik kajszifajta szirma legalább 90 \%-ban elpusztult. Ezek alapján az eltérés a kajszifajták sziromfogékonysága között nem határozhatja meg az ellenállóképességet, mert a teljes sziromfertőzés mindegyik genotípusnál kialakult. Az $P$. cerasifera és a 'Zard' kajszifajta esetében tapasztalt ellenállóság alapján viszont az immunis fenotipus gyorstesztjeként szolgálhat a sziromfertőzés. A cseresznyeszilva szirmok mutatták a vizsgált genotípusok közül a legnagyobb ellenállóságot, a teljes szirompusztulásig három nap telt el.

\subsection{A megporzás és virágfertôzés közti összefüggés vizsgálatának eredményei}

A fertőzés lefolyására széles körben elfogadott hipotézis a $M$. laxa konídiumainak a bibén keresztüli virág fertőzése. Az elképzelés, ahogy egy 1930-ban készült rajz is mutatja, a bibe barnulása alapján feltételezi a kórokozó növénybe történő behatolását (Kerekes, 1930). E szerint a csonthéjas fajok virágfertőzésénél a M. laxa konídiumai a bibecsatornán keresztül a pollen csírázásához hasonlóan fejlődnek és az elsődleges virágpusztulás kialakulása után a termőrészek pusztulását okozzák. A hipotézis alapján Tzoneva és Tzonev (1999) arra keresték kísérleteikben a választ, hogy a megporzott bibéken keresztül bekövetkezhet-e a virágfertőzés. A kérdésfelvetés alapját a kajszinemesítők körében ismert jelenség a keresztezett ágak ellenállósága adta. Megfigyeléseik szerint a kasztrált és megporzott ágakon nem volt megfigyelhető a fertőzés, de ennek a kontrollját nem végezték el, ami a kasztrált és megporzatlan kezelés lett volna. Helyette a megporzott, de nem kasztrált ágakon tapasztalható 12 \% virágfertőzést azzal magyarázták, hogy a megporzás után a bibe 
a gomba konídium fejlődését gátló anyagot szintetizált (szabadelvirágzású kontroll ágakon $60 \%$-os fertőzést mértek). A papírzacskóval és vászonzsákkal izolált, öntermékenyített ágakon ezzel szemben 75 és $95 \%$-os fertőzést tapasztaltak, ami nem magyarázza a feltételezést, miszerint a fertőzés kizárólag a nem megporzott bibéken keresztül történhet meg, habár a fajtákról nem közölték öntermékenyek-e. Az két fogékony fajtán beállított kísérlet alapján tisztáztuk a megporzás hatását a fertőzésre. A kasztrált és megporzott ágak esetében a virágok $7 \%$-a fertőződött meg, míg a kasztrált és megporzatlan ágak esetében a virágok 10,5\%-a pusztult el 'Kecs-psár' fajtán. A 'Goldrich’ fajtán végzet kísérletben a kasztrált és megtermékenyített 111 virág esetén egyetlen alkalommal, míg a 118 kasztrált és megporzatlan virág esetében egyetlen alkalommal sem történt meg a fertőzés. A 'Kecspsár’ fajtán tapasztalt fertőzés a kasztrálás ellenére is kialakult, ami a fajtán megfigyelt spontán fertőzéssel (virágzást megelőzve fertőződtek a virágrügyek) magyarázható. A 'Goldrich' fajta esetében a fertőzés elmaradását nem a bibék megporzása, hanem az infekciós pontnak tekinthető fogékony virágrészek mechanikai eltávolítása okozta. A megporzás nem volt hatással a virágfertőzés kialakulásának gyakoriságára.

A bibe környékének antifungális hatását tapasztaltuk a gomba fejlődésekor. A táptalajra helyezett bibéből a korábban Halász (2007) által is bemutatott módon, extracelluláris ribonukleázok választódtak ki a táptalajba, amit a Torula élesztő RNS-ének festésével mutattunk ki. A táptalaj felületén növő gombamicélium fejlődését gátló zóna mérete, hasonlóan az RNS festéses kimutatással, a bibe körül alakult ki.

A bibéből kiáztatott intercelluláris folyadék a konídiumok csírázását gátolta, illetve a kicsírázott micélium fejlődését teljesen leállította. A dohányból származó 'S-like' ribonukleázok két kórokozó gombának csírafejlődését hasonlóképp gátolták Hugot és mts. (2002) kísérleteiben, ezért feltételezhetjük, hogy a bibében kifejeződő S- ribonukleázok az idegentermékenyítés biztosításán túl a bibe kórokozók elleni védelmében játszik szerepet.

\subsection{Mesterséges termőrészfertőzés eredményei}

A kajszifajták és mandulafajták $M$. laxa ellenállóságának vizsgálatára CrossaRaynaud (1969) közölt egy mesterséges ágfertőzési technikát. A vizsgálataik során a levágott kétéves ágakon sebzéseket ejtettek, amiket $M$. laxa által átszőtt agarkorongokkal fertőztek meg. Eredményeik szerint az ültetvényben tapasztalt fajták fogékonysága és a mesterséges ágfertőzés során tapasztalt háncsszövet pusztulás hossza között egyértelmü összefüggés állt fenn. A technikát több kajszinemesítési program során alkalmazták 
(Gulcan és mts., 1999, Nicotra és mts., 2006) mint a fenotipizálás felgyorsításának lehetőségét. Ezzel szemben Szügyi és mts. (2012) meggyen végzett kísérletei alapján leírják, hogy a mesterséges vesszőfertőzés során az immunisnak tartott 'Csengődi' és az egyik legfogékonyabb meggyfajta az 'Érdi bőtermő' esetében azonos hosszúságú termőrész pusztulást tapasztaltak.

Az ültetvényi fertőzések alapján ellenállónak azonosított 'Zard' és fogékonynak tartott 'Kecs-psár' fajtákon alkalmaztuk a fent említett fertőzési eljárást. A háncsszövet pusztulása mindkét fajta esetében azonos mértékü volt és a fertőzést követő 30 . napra a levágott ágak háncsszövetének teljes hosszára kiterjedt a nekrózis. Ezzel megegyező eredményekről számol be Gulcan és mts. (1999) kajszi mesterséges vesszőfertőzésekor. A nyári fertőzést ezek alapján túlságosan provokatívnak találtuk, ezért a vesszőfertőzést ősszel alkalmaztuk az ültetvényben a 'Zard és 'Korai zamatos' fajtákon és ezek 48 hibridből álló utódpopulációján. A vesszőfertőzést választottuk az ágfertőzéssel szemben, mert a természetes $M$. laxa fertőzés is ezeken a növényi részeken jelentkezik.

A fertőzés értékelésekor meglepő eredményt kaptunk. A 'Zard' fajta esetében a fertőzött szövetek hosszúságának átlaga nagyobb volt, mint a fogékony 'Korai zamatos' fajtán mért pusztulás, habár ez az eltérés a nagy szórás miatt nem volt szignifikáns. Ez a megfigyelés teljes mértékben ellentmond Crossa-Raynaud (1969) ágfertőzése során leírt pusztult szövetrészek hosszának felmérésével.

A fertőzött háncsszövet hossza ez alapján nem alkalmas az egyedek ellenállóképességének meghatározásához viszont a fertőzött és ép szövetek határán az ellenálló 'Zard' és fogékony 'Korai zamatos' fajták esetében eltérést tapasztaltunk. Az ellenálló fajta - 'Zard' - esetében a vessző háncsszövet pusztulása éles szegéllyel határolódott el a barna nekrotizált szövetektől. Az ép szövet megvastagodása volt megfigyelhetö, míg a fogékony fajta esetében egy elmosódó határ volt az ép és fertőzött szövetek között. E megfigyelés szerint értékeltük a 48 hibridet. Harmincegy egyed mutatta a fogékony és 17 az ellenálló fajtára jellemző reakciót. Az M. laxa elleni rezisztencia öröklődésével kapcsolatban korábban egyöntetüen, mint domináns jellegről számolt be Crossa-Raynaud (1969), Gulcan és mts. (1999) és Nicotra és mts. (2006), mert a hibridek túlnyomó része a rezisztencia forrásként alkalmazott szülőhöz hasonlóan ellenálló volt. Természetesen a hibrid család alacsony egyedszáma alapján csak feltételezhetjük az ellenállóság öröklődésének menetét, de feltételezve, hogy a Zard heterozigóta formában hordozza a domináns allélként működő 
rezisztenciát, a fogékony és ellenálló utódok aránya 3:1 mendeli monogénes domináns öröklődéshez közelít.

Az ellenálló és a fogékony hibridek vesszőfertőzés hosszának összehasonlítása alapján, az ellenálló egyedek vesszőin látható fertőzési terület egyértelmüen rövidebb volt a fogékony utódokhoz képest, habár az egyedeken belüli pusztult háncsszövet hossza nagy eltéréseket mutatott. A vesszőátmérő és az elpusztult szövethossz között nem találtunk korrelációt.

A kajszi esetében több nemesítő és kutató (Crossa-Raynaud 1969, Gulcan és mts., 1999 és Nicotra és mts., 2006) által alkalmazott mesterséges monilia fertőzés eredményei alapján megállapítható, hogy a fertőzési technika során alkalmazott micéliummal átszőtt táptalaj korongok a kórokozónak olyan tápanyagforrást biztosítanak, amely annyira növeli a fertőzés intenzitását, hogy ennek következtében az ellenálló fajták és hibridek esetében fogékony genotípusokkal azonos hosszban alakulnak ki a fertőzés tünetei.

\subsection{Az 'Orange red' és 'Zard' fajta mesterséges levélfertôzésének eredményei}

A M. laxa kórokozó levélfertőzését figyeltük meg az ültetvényben. Az elpusztult hajtásokon kialakult exogén sztrómákról lefüződő konídiumok a közelükben található fiatal leveleken barna léziókat okoztak, amik később az egész levéllemezre kiterjedtek. A jelenséget már Byrde és Willetts (1977) is megfigyelte, habár mint kártétel nem tarják számottevő jelentőségűnek. Ezek a tünetek nem voltak tapasztalhatók a 'Zard' fajta levelein, amire két magyarázat is adható. A 'Zard' fajtán a virág és hajtásfertőzés is ritkán fordult elö, így a fertőzési inokulum hiánya miatt nem történt meg a levelek pusztulása. A másik lehetőség, hogy a levél mint zöld növényi rész aktív ellenálló képességgel gátolja meg a konidíumok fertőzését. A kérdés eldöntésére mesterségesen fertőztük meg a levélkéket. A hajtásokról leválasztott levelek fertőzésekor az 'Orange red' fajta esetében két nappal a fertőzést követően a levélfelület $30 \%$-a teljesen nekrotizálódott, míg ekkor a 'Zard' esetében még nem volt megfigyelhető a pusztulás. A fertőzést követő 72 órában az összes 'Orange red' levél teljesen kolonizálódott, a 'Zard' fajta levélkéin is megjelentek a tünetek a fertőzési pont körül. A kísérlet alapján az ellenállóság másik megnyilvánulási formáját mutattuk be, ami a későbbiekben a bizonytalan vessző és ágfertőzésnek felváltására kínál lehetőséget. A levélfertőzés a kajszinemesítés számára a teljes vegetációs időben végezhető gyorsteszt lehet, amihez a pontos standardok és paraméterek kidolgozása szükséges. 


\subsection{Az NBS-típusú RGA-k és a monilia-ellenállóság kapcsoltsága}

Szőlő és alma esetében a funkcionális RGA markerek alkalmazásakor sikerült több növényi rezisztenciával kapcsoltságot kimutatni. A szőlő esetében Di Gaspero és Cipriani (2002) peronoszpóra ellenállósággal, Donald és mts. (2002) lisztharmat rezisztenciával kapcsolatot mutató NBS típusú RGA szekvenciákat azonosított. Az alma ventúria-ellenállósággal kapcsolt RGA szekvenciák meghatározásáról számoltak be Calenge és mts. (2005).

A RGA szekvenciák változékonyságát általában szekvenálás alapján, illetve az RGA szekvenciák környékén található restrikciós hasítóhelyek változékonysága alapján mutatták ki (Calenge és mts., 2005). Munkánk során a kajszifajták NBS RGA szekvenciák polimorfizmusának vizsgálatára az SSCP technikát választottuk. Vizsgálataink során az NBS gének minél szélesebb körének kimutatása érdekében új PCR stratégiát dolgoztunk ki.

Kajszi esetében az NBS-LRR típusú RGA-k izolálásával foglalkozó publikációk csak a TIR-NBS-LRR típusú csoportba tartozó szekvenciákról számoltak be (Soriano és mts., 2005; Baldi és mts., 2004; Lalli és mts., 2005), és arra a következtetésre jutottak, hogy kajszi esetében a két csoport tagjai egyenlötlen arányban találhatók meg vagy az alkalmazott technika TIR-NBS szekvenciákra volt specifikus.

Ezért elsőként olyan primereket kellett terveznünk, amelyek mind a kétféle NBS szekvenciát amplifikálják a PCR során, ezzel biztosítva az NBS szekvenciák legszélesebb körben történő vizsgálatát. Elsőként izoláltunk a CC típusba tartozó RGA-kat kajsziból. A Soriano és mts. (2005) által alkalmazott technika eredménytelensége nagy valószínüséggel annak tudható be, hogy az általuk alkalmazott degenerált primereket Gentzbittel és mts. 1998-ban mindössze az akkor ismert három Arabidopsis szekvencia alapján tervezték. Ezzel szemben az általunk 26 szekvencia alapján tervezett degenerált primerek nagyobb polimorfizmust engednek meg az NBS domén konzervált P-loop és hidrofób régióin. A TIR és CC-NBS-LRR szekvenciák elkülöníthetők az NBS domén bizonyos aminosavmotívumai alapján (Penuela és mts., 2002). Ezt az általunk készített aminosav-illesztés is alátámasztotta. Ilyen specifikus motívum a Kináz II régió N-terminális oldala felé található triptofán, melynek segítségével a CC-NBS-LRR típusú szekvenciákhoz szelektíven kötődő primert (Kin2 F) terveztünk. A szekvenciák ismerete alapján igazolható, hogy a szelektív 
Kin2 F és HD R primerekkel végzett semi-nested PCR valóban csak a CC-NBS-LRR típusú szekvenciák felszaporítását eredményezte.

A saját tervezésű primerek lehetőséget biztosítottak mindkét NBS LRR géncsoport vizsgálatára az SSCP analízis során. Az SSCP analízis során háromszoros mennyiségü fragmentumot tudtunk vizsgálni a Soriano és mts. (2005) által alkalmazott primerkombinációval felszaporított fragmentumok számához képest.

A monilia ellenálló 'Zard' kajszifajta esetében nem sikerült a PCR termékek SSCP vizsgálatával csak erre a fajtára specifikusan megjelenő fragmentum azonosítanunk, ami természetesen nem zárja ki az ellenállóság kialakításában az NBS-LLR típusú rezisztenciagének szerepét.

\subsection{Az újonnan azonosított RGA-k molekuláris vizsgálata}

Az adatbázissal való illesztés alapján minden kétséget kizárólag megállapíthatjuk, hogy sikeresen izoláltunk új CC- és TIR- NBS típusú RGA-kat a kajszi 'Goldrich’ fajtájából. A 293 Rosaceae fajból származó szekvencia (Samuelian és mts., 2008) és 21 annotált rezisztenciagén alapján készített törzsfán a szekvenciáink négy csoportba rendeződtek el. A két föcsoportra osztott fán megfigyelhető volt, hogy a CC-NBS szekvenciákat tartalmazó ágon a $70 \%$-os bootstrap értékkel létrehozott csoportokban nagyobb arányban találhattuk meg az eltérő nemzetségekből származó szekvenciákat, az elágazásai jelentősen a törzsfa alapi része felé tolódtak el a TIR csoporthoz képest. A TIR csoport szekvenciái a törzsfán nagyobb arányban jelentek meg nemzetségspecifikus csoportokban, és a csoportok elágazódásai terminális elhelyezkedésűek voltak a CC csoporthoz képest. A genomszekvenciák alapján kigyüjtött NBS szekvenciák filogenetikai vizsgálatakor Yang és mts. (2008) hasonló eredményekről számol be a nyár, szőlő, rizs és lúdfü esetében. Ez alapján megállapítható a CC-NBS szekvenciák a vizsgált fajok szétválása előtt már kialakultak, míg a TIR-NBS szekvenciákra fajspecifikus elrendeződésük a fajok kialakulása utáni szekvenciasokszorozódás adhat magyarázatot.

A szekvenciák filogenetikai analízise alapján feltételezhetjük, hogy ezek között a szekvenciák között nem csak hasonlóság áll fenn, hanem evolúciós eredetük is közös. Ezért ezeket a szekvenciákat helyesebb rezisztenciagén-homológoknak nevezni, mivel az analógia evolúciós eredettől független hasonlóságot jelent (Patthy, 2007). 


\subsection{A moniliára fogékony 'Orange red' és az ellenálló 'Zard' fajták között fertőzés hatására kialakuló génexpressziós eltérések}

A két fajta esetében négy primerkombináció alkalmazásával összesen 29, a fertőzésére megjelent fragmentumot azonosítottunk a gélelektroforézis során, amiből 18-nak meghatároztuk a szekvenciáját. Az őszibarack M. laxa gyümölcsfertőzésére kialakuló transzkriptomikai változásokat cDNS- AFLP technikával követte nyomon Zubini (2008) doktori munkájában. Primerkombinációnként 50-70 fragmentumokat azonosított mindegyik vizsgált őszibarack mintában. A fertőzés hatására a fragmentumok megjelenése a gélen 20-35\%-ban változott meg. Az általunk alkalmazott négy primerkombináció segítségével nyert fragmentumoknak a becsült száma, mintánként 50-200 darab között változott a primerkombináció függvényében. A fertőzött vesszőkből származó mintákban $10 \%$-ban kaptunk új fragmentumokat.

Egy szekvencia esetében a külső fertőzést bizonyító Pseudomonas szaprofág baktérium szekvenciájával találtunk hasonlóságot, annak ellenére, hogy a vesszők fertőzés melletti ép részéből izoláltuk az RNS-t. Zubini (2008) munkájában a 339 TDF szekvencia a fele mutatott növényi génekkel azonosságot, $40 \%$-a Pseudomonas fajokból származott és $10 \%$-a gomba eredetü volt. Erre magyarázat lehet, hogy a gyümölcsfertőzés során nem különül el élesen a fertőzés határa, így az ép és a fertőzött gyümölcsminták közötti mRNSek eltérésének felét nem a növényi választ biztosító gének, hanem gomba és baktérium gének adták.

A 18 szekvencia közül csak 11-et találtunk meg az őszibarack genomban, amire magyarázatot adhat a túl rövid (100 bp körüli) fragmentumok direktszekvenálása.

Az egyik azonosított fragmentum, amely 15. TDF a 'Zard' fertőzött I. mintákból származott, homológiát mutat a növényvilágban széles körben megtalálható poligalakturonáz gátló fehérje (PGIP) szekvenciájával. A gyümölcsfertőzés vizsgálatából származó eredmények alapján Fielding (1981) beszámol egy poligalkturonáz gátló fehérjéről, ami fertőzés hatására jelenik meg a gyümölcsökben (alma, szilva és őszibarack), és képes a Monilinia fajok poligalakturonáz-aktivitását nagymértékben gátolni.

A PGIP enzim specifikusan képes eltérő növénypatogén gombafajok poligalakturonáz gátlására, amit elsőként Albersheim és Anderson, (1971) kísérleteiben bizonyított. A Venturia-fogékony és ellenálló körték PGIP fehérjéi összehasonlításakor Faize és mts. 
(2003) megfigyelték, hogy az ellenálló fajtából izolált PGIP enzim 2-3 szoros gátlást okoz a Venturia PG-zal szemben.

A PGIP gén expressziójáról megállapítottuk, hogy sem az ellenálló sem a fogékony fajta fertőzetlen mintáiban nem volt jelen. A fertőzés hatására az ellenálló és fogékony kajszi fajták vesszőjében több PGIP allél jelent meg. Arabidopsis esetében Ferrari és mts. (2003), almánál Yao és mts. (1999), bab esetében Oliveira és mts. (2010) számolnak be, hogy gombafertőzés hatására többszörösre növekedett a PGIP gének kifejeződése a megtámadott szöveti részben.

A két fajtában ('Zard' és 'Orange red') a PGIP allélok száma öt és hat volt. a várt néggyel szemben, ezért azt feltételezzük, hogy a nukleotid eltérésének egy része a reverz transzkripció és PCR reakció során hibásan alakult ki. A várt négy allélt az őszibarack és alma genomban meghatározott PGIP gén két - két paralóg kópiája alapján feltételezzük, de a hat allélt még esetlegesen megmagyarázhatja, ha a PGIP gén a kajszigenomban három kópiában lenne jelen. A cDNS AFLP során meghatározott 15. TDF szekvenciát nem sikerült megtalálnunk a megszekvenált klónok között. Ezért további primerek tervezés és kísérletek szükségesek a 15. TDF szekvenciájának meghatározásához.

Leckie és mts. (1999) szerint egyetlen aminosav csere a bab PGIP génjében új kórokozó elleni gátlás kialakulásáért volt felelős, így további kísérleteink során elsőként genomi DNS-ból kívánjuk meghatározni a fajták valós PGIP szekvenciáját, így elkerülve a reverz transzkripció során kialakuló mutációkat. A cDNS AFLP során meghatározott PGIP allél (15.TDF) öröklődését és kapcsoltságát az ellenálló fenotípushoz a 'Korai zamatos' $\mathrm{x}$ 'Zard' fenotipizált egyedein kívánjuk bizonyítani. 


\section{7 Új tudományos eredmények}

1. A moniliás termőrész pusztulás bonitálása alapján harmincegy kajszifajta közül a 'Zard' fajta nagyfokú, a termőrészek háncsszövetében kialakuló válaszreakción alapuló monilia rezisztenciát mutatott.

2. Bebizonyítottuk, hogy a korábbi nézetekkel ellentétben a kajszi esetében a fertőzés nem a bibén keresztül történik. A virágfertőzés kialakulására nincs hatással a bibe megporzása.

3. Kimutattuk, hogy a bibe szövetében képződő ribonukleáz aktivitású extracelluláris váladék a $M$. laxa konídiumok csírázását és micéliumának növekedését gátolja.

4. Megállapítottuk, hogy a 'Zard' és 'Korai zamatos' fajták keresztezéséből származó hibridek között a mesterséges vesszőfertőzés hatására a 'Zard' fajtára jellemző szöveti válaszreakciók jelentek meg, ami a rezisztencia örökölhetőségére utal.

5. Kialakítottunk egy szelekciós rendszert, amely a bizonytalan vesszőfertőzés helyett a sziromlevelek és levelek mesterséges fertőzése révén lehetőséget ad a fajták gyors fenotipizálására.

6. A kajszi esetében elsőként izoláltunk CC-NBS-LRR RGA szekvenciákat. A NBS RGA szekvenciák és a monilia ellenállóság között nem sikerült összefüggést találnunk.

7. A háncsszövet-transzkriptomban azonosítottunk egy, a PGIP génhez nagy hasonlóságot mutató szekvenciát, mely a moniliafertőzés hatására, és specifikusan az ellenálló fajtában jelent meg. 


\section{8 Összefoglalás}

A doktori dolgozatom a kajszi virágzáskori moniliás betegségével szembeni ellenállóság vizsgálatainak eredményeit foglalja össze. A 31 kajszifajta fogékonyságát határoztuk meg természetes fertőzés bonitálásával három egymást követő év során. Megbízható rendszert dolgoztunk ki a fajták összehasonlítására, a genotípusok ellenállóságát az elpusztított termőrészek arányával jellemeztük. Két $P$. salicina fajtáról, $P$. cerasifera és $P$. dasycarpa fajok egyedei esetében teljes ellenállóságot állapítottunk meg. A kajszi fajták közül a 'Zard' fajta ellenállósága kimagasló volt. A magyarkajszi fajtakör esetében megfigyelt ellenállóság a fajták alacsony virágszámával és a hosszú termőrészek teljes hiányával magyarázható, ami az extenzív ültetvényi körülmények hatására alakult ki.

Két fajta esetében összehasonlítottuk a megporzott és megporzatlan bibék ellenálló képességét a kórokozó támadásával szemben, és megállapítottuk, hogy a bibe teljes immunitását nem befolyásolja a megporzás. A kajszi bibéből származó szekrétum in vitro körülmények között megakadályozta a micélium növekedését. Feltételezhető, hogy a gátlóhatás a ribonukleáz enzimek jelenlétével magyarázható.

Megállapítottuk, hogy a virág fertőzése során a szirmok és porzószálak szolgálnak infekciós pontként. A szirom szöveti felépítése magyarázatot ad a nagy intercelluláris járataival és az epidermisz sejtek vékony sejtfalával a kórokozó gyors terjedésére. A gomba micélium a vacoköblön keresztül a vesszők háncsszövetébe jut.

A szirmok mesterséges fertőzése alapján megállapítottuk, hogy a vizsgált 12 fajta esetében az eltérő fogékonyságot nem a szirom ellenállósága biztosítja, habár a fajták között tapasztaltunk eltérést, a fertőzést követő 45 órára mindegyik kajszifajta szirma teljes egészében elpusztult.

A 'Zard' és 'Korai zamatos' fajták és ezek 43 hibridjének mesterséges vesszőfertőzése alapján megállapítottuk, hogy a vesszőfertőzés hossza nincs összefüggésben az egyedek ellenállóságával. Az ellenálló 'Zard' fajtán élesen elhatárolódott az ép és fertőzött szövetrész. Az élő háncsszövet a fertőzést megvastagodva vette körül. Az utódok között 13 esetében tapasztaltunk, ehhez hasonló ellenálló szöveti választ.

Kifejlesztetünk egy NBS-LRR rezisztenciagén analógok mindkét csoportját kimutató PCR eljárást, amivel kajszi esetében elsőként mutattunk ki CC-NBS-LRR szekvenciákat. A korábban alkalmazott és az általunk tervezett primerek felhasználásával hét 
fogékony és egy ellenálló fajta RGA szekvenciáinak összehasonlító vizsgálatát SSCP technika alkalmazásával végeztük el. Az ellenálló fajta esetében nem sikerült egyedi fragmentumot meghatároznunk.

A 'Zard' fajta természetes virágfertőzését követően a virágkocsány körül a háncsszövet néhány milliméteres pusztulása után a fertőzés leállt, a háncsszövet a fertőzött szövet körül megvastagodott. Ez alapján az 'Orange red' és 'Zard' fajták eltérő háncsszövet válaszreakcióját vizsgáltuk meg cDNS-AFLP technika alkalmazásával. A 'Zard' fajta fertőzött mintáiból sikerült kimutatnunk egy nekrotróf gombakórokozó fejlődését gátló növényi poligalakturonáz gátló fehérje szekvenciájával nagy hasonlóságot mutató cDNS szakaszt. A szekvencia a Prunus americana, Prunus mahaleb és Prunus salicina fajok PGIP szekvenciáival $95 \%$-os azonosságot mutatott. A fertőzés hatására a fogékony fajtában is kimutatható volt a PGIP gének expressziója, ez alapján feltételezzük, hogy a PGIP allélok közötti eltérés biztosítja a 'Zard' fajtára jellemző ellenálló képességet.

Munkánk során sikerült a kajszi moniliás betegségével szemben ellenálló kajszifajtát meghatároznunk. Ez a fajta biztosíthatja a monilia ellenállóságot a kajszi nemesítés számára. A 'Zard' fajta korona habitusa, hosszan tartó mélynyugalmi állapota, a monilia ellenállósága alapján a vizsgált kajszi fajtáktól jelentősen eltér, ezért ez alapján feltételezzük a fajta interspecifikus eredetét. 


\section{Summary}

The resistance of apricot against blossom blight caused by Monilinia laxa was studied in this thesis. The research is summarized as follows:

Sensitivity of 31 apricot cultivars was determined based on evaluation of natural infection performed in 3 consecutive years. A reliable system was estabilished for comparision of the cultivars. The resistance of genotypes was characterized by the ratio of intact and destroyed fruit sets. Absolute M. laxa immunity was found in two cultivars of $P$. salicina and some specimens of $P$. cerasifera and $P$. dasycarpa species. Among apricot cultivars a similar immunity was demonstrated only by 'Zard'. The resistance of the Magyarkajszi cultivar group was found to derived from the low number of flowers and the complete lack of long fruitshoots which is typical in extensive orchards.

We clarified that in the apricot breeding the resistance of the crossed branches doesn't derive from pollination process. We compared the resistance of pollinated and nonpollinated pistils were compered and no difference was found. The secretum from the apricot pistil inhibited the M. laxa hyphal elongation in vitro. Presumably the inhibition effect can be explained by the presence of ribonuclease enzymes.

In the blossom infection process the fungi penetrate through petales and stamens. The petal's histology with its huge intercellulars and thin cellwall of the epidermic cells explains the rapid spread of $M$. laxa myceliums. The patogen can easily enter the phloem through the receptacle.

Artificial infection of the petals of 12 apricot cultivars resulted in complete colonization of the tissues in 45 hours post infection. Some differences were detected in the speed of the colonization among the cultivars however it can not be the source of resistance since in 45 hours all the cultivars - including the resistant ones - have been destroyed.

Based on the artificial shoot infection of 'Zard', 'Korai zamatos' and their 43 hybrids no correspondence was found between the lenght of destroyed shoot and the resistance of the individuals. In case of 'Zard' the intact and infected tissues were strictly separated. The infection was isolated from the healthy tissues by a thickened phloem. This type of tissue response was detected on 13 progenies. 
We have A PCR method was developed for the detection of both groups of NBSLRR resistance gene analogs. With this method we were able to detect CC-NBS-LRR RGA in apricot genome. SSCP polimorphism of RGA sequences of 7 sensitive and one resistant apricot cultivars were compared. In the case of the resistant cultivar no unique fragment was found.

Following the natural infection of 'Zard' flowers a limited destruction was found in the tissue surrounding the peduncle however in a short time the infection was completely inhibited, the phloem around the infected tissues has been thickened. cDNA AFLP technique was used for following the different response of 'Orange red' and 'Zard' cultivar to Monilinia infection.

cDNA AFLP technique research resulted in a unique transcript derived fragment (TDF) which shows similarity with plant poligalacturonase inhibiting protein (PGIP). This TDF appeared only in the infected 'Zard' samples. The highest identity rate (more than 95\%) of this TDF nucleotide sequence was found to the PGIP sequences of the Prunus americana, Prunus mahaleb and Prunus salicina species. As a result of infection the PGIP gene were expressed in both cultivars. It may be hypothesized that the differences in sensitivity are caused by the PGIP alleles.

As a result of our research we were able to identify an apricot cultivar - namely 'Zard' - resistant to M. laxa shoot infection. That cultivar may provide the source of $M$. laxa resistance in apricotbreeding. Special traits of 'Zard' like habit of crown, outstanding winter hardiness, long peduncle and monilia resistance suggest the interspecific origin of the cultivar. 


\section{Köszönetnyilvánítás}

Köszönetet szeretnék mondani konzulensemnek Dr. Pedryc Andrzej egyetemi tanárnak a munkám során nyújtott támogatásáért, ami nélkül nem készülhetett volna el dolgozatom.

A munka során nyújtott segítségért hálával tartozom a Genetika és Növénynemesítés Tanszék mindenkori kollégáinak. Köszönöm Dr. Deák Tamás 'szobatársamnak' a bioinformatika alapjainak elsajátításában nyújtott segítségét. Köszönöm Bacskainé Pap Annának, Tóth Veronikának, Millei Ágnesnek, Zaheri-A Sabourannak a labormunkákban nyújtott segítségét. Köszönöm Hermán Ritának azt a nagyon sok háttér munkát, ami nélkül nem tudtam volna munkámat végezni. Köszönöm Dr. Pfeiffer Péternek, Dr. Szikriszt Bernadettnek a laborban, Lendvay Bertalannak a statisztikai elemzéseknél nyújtott segítségét. Köszönöm Dr. Hegedűs Attilának a publikációk elkészítésénél nyújtott támogatását és a dolgozat javítását. Köszönöm Benyóné Dr. György Zsuzsának a dolgozat megírásában és javításában történő segítségét és a bíztatását. Köszönöm Dr. Halász Júlia gödöllői vonatút alatt adott bátorítását a doktori munka elkezdéséhez.

Köszönöm Rőth Fruzsina hallgatóm szorgalmas, odaadó munkáját, és Földi Tímeának az SSCP technika alkalmazásához nyújtott segítségét.

Feleségemnek köszönöm a végtelen türelmét és kitartását. 


\section{Mellékletek}

\section{Irodalomjegyzék}

1. Abu-Goukh, A. A., Greve, L. C., Labavitch J. M. (1983): Purification and partial characterization of 'Bartlett' pear fruit polygalacturonase inhibitors. Physiol. Plant. Pathol., 23: 111-122.

2. Agrawal, K. M., Bahl, L. O. P. (1968): Glycosidases of Phaseolus vulgaris Isolation and general properties. J. Biol. Chem., 243: 103-111.

3. Agrios, G. N. (1997): Plant patholgy. Academic Press, Inc., California. 257.

4. Aguero, C., Uratsu, S., Greve C., Powell A., Labavitch, J., Meredith, C., Dandekar A. M. (2005): Evaluation of tolerance to Pierce's diseaseand Botrytis in transgenic plants of Vitis vinifera L. expressing thepear PGIP gene. Mol. Plant Pathol., 6: 43-51.

5. Albersheim, P. (1965): The substructure and function of the cell wall. In: J. Bonner and J. E. Varner, eds., Plant Biochemistry. Academic Press, Inc., New York. 151-186.

6. Albersheim, P., Andersona, J. (1971): Proteins from plant cell walls inhibit polygalacturonases secreted by plant pathogens. Proc. Nat. Acad. Sci. U.S.A., 18151819.

7. Albersheim, P., Jones, T. M., English, P. D. (1969): Biochemistry of the cell wall in relation to infective processes. Annu. Rev. Phytopathol., 7: 171-194.

8. Altschul, S. F., Gish, W., Miller, W., Myers, E. W., Lipman, D. J. (1990): Basic local alignment search tool. J. Mol. Biol., 215: 403-410.

9. Andersen, J., Lübberstedt, T. (2003): Functional markers in plants. Trends Plant Sci., 11: 557-514.

10. Arabidopsis Genome Initative (2000): Analysis of the genome sequence of the flowering plant Arabidopsis thaliana. Nature, 408: 796-815.

11. Arts M. G., Hekkert B., Holub E. B., Beynon J. L., Stiekema W. J., Pereira A. (1998): Identification of R-gene homologous DNA fragments genetically linked to disease resistance loci in Arabidopsis thaliana. Mol. Plant-Microbe Interact., 11: 251- 258.

12. Balan, V., Toma, S., Oprea, M. (1999): Reaction of apricot phenotypes from national collection to the Monilinia laxa (Aderh. et Ruhl.) Honey inoculum. Acta Hort., (ISHS) 488: 667-670.

13. Baldi P., Patocchi A., Zini E., Toller C., Velasco R., Komjanc M. (2004): Cloning and linkage mapping of resistance gene homologues in apple. Theor. Appl. Genet., 109: 231-239.

14. Bassam, B. J., Gresshoff, P. M. (2007): Silver staining DNA in polyacrylamide gels. Nature Protocols, 2: 2649-2654.

15. Benedek, P., Nyéki, J., Vályi, I. (1990): Csonthéjas gyümölcsfajták érzékenysége a fontosabb kórokozókkal és kártevőkkel szemben - a fajtaspecifikus növényvédelmi technológia kidolgozása. Növényvédelem, 26: 12-31. 
16. Bergmann, C. W., Ito, Y., Singer, D., Albersheim, P., Darvill, A. G. (1994): Polygalacturonase-inhibiting protein accumlates in Phaseolus vulgaris L. in response to wounding, elicitors and fungal infection. Plant J. 5: 625-634.

17. Byrde, R. J. W., Fielding, A. H., William, S. A. H. (1960): The role of oxidised polyphenols in the varietal resistance of apples to brown rot. In Phenolics in Plants in Health and Disease, 95-99. Edited by J. B. Pridham. Oxford: Pergamon Press.

18. Byrde, R. J. W., Fielding, A. H. (1968): Pectin methyl-trans-eliminase as the maceration factor of Sclerotinia fructigena and its significance in Brown Rot of apple. J. Gen. Microbiol., 52: 287-298.

19. Byrde, R. J. W., Willetts, H. J. (1977): The brown rot fungi of fruit. Their biology and control. Pergamonn Press, Oxford 171.

20. Carter, C., Thornburg, R. W. (2004): Is the nectar redox cycle a floral defence against microbial attack? Trends Plant Sci. 9: 320-324.

21. Calenge, F., Van der Linden, C. G., Van de Weg, W. E., Schouten, H. J., Van Arkel, G., Denancé, C., Durel, C. E. (2005): Resistance gene analogues identified through the NBS-profiling method map close to major genes and QTL for disease resistance in apple. Theor. Appl. Genet., 110: 660-668.

22. Cervone, F., De Lorenzo, G., Degra, L., Salvi, G., Bergami, M. (1987): Purification and characterization of a polygalacturonase-inhibiting protein from Phaseolus vulgaris L. Plant Physiol., 85: 631-648.

23. Cervone, F., Hahn, M. G., De Lorenzo, G., Darvill, A., Albersheim, P. (1989): Hostpathogen interactions XXXIII. A plant protein converts a fungal pathogenicity factor into an elicitor of plant defence responses. Plant Physiol., 90: 542-548.

24. Collins, N. C., Webb, C. A., Seah, S., Ellis, J. G., Hulbert, S. H., Pryor A. (1998): The isolation and mapping of disease resistance gene analogs in maize. Mol. Plant. Microbe. Interact., 11: 968-978.

25. Creusot F., Macadre C., Ferrier-Cana E., Riou C., Geffroy V., Sevignac M., Dron M., Langin T. (1999): Cloning and molecular characterization of three members of the NBS-LRR subfamily located in the vicinity of the Co-2 locus for anthracnose resistance in Phaseolus vulgaris. Genome, 42: 254-264.

26. Crossa-Raynaud, P. H. (1969): Evaluating resistance to Monilia laxa (Aderh. \& Ruhl.) Honey of varieties and hybrids of apricot and almonds using mean growth rate of cankers on young branches as a criterion of susceptibility. J. Amer. Soc. Hort. Sci., 94:282-284.

27. Dangl, J. L., Jones, J. D. G. (2001): Plant pathogens and integrated defence responses to infections. Nature 411: 826-833.

28. De Lorenzo, G., Ito, Y., D’Ovidio, R., Cervone, F., Albersheim, P., Darvill, A. G. (1990): Host-pathogen interactions XXXVII. Abilities of the polygalacturonaseinhibiting proteins from four cultivars of Phaseolus vulgaris to inhibit the endopolygalacturonases from three races of Colletotrichum lindemuthianum. Physiol. Mol. Plant Pathol., 36: 421-435.

29. Decroocq, V., Foulongne, M., Lambert, P., Gall, O., L., Mantin, C., Pascal, T., Schurdi-Levraud, V., Kervella, J. (2005): Analogues of virus resistance gene map to 
QTLs for resistance to sharka disease in Prunus davidiana. Mol. Genet. Genomics, 272: 680-689.

30. Di Gaspero, G., Cipriani, G. (2002) Resistance gene analogs are candidate markers for disease-resistance genes in grape (Vitis spp.). Theor. Appl. Genet., 106: 163-172.

31. Di Matteo, A., Federici, L., Mattei, B., Salvi, G., Johnson, K., A., Savino, C., De Lorenzo, G., Tsernoglou, D., Cervone, F. (2003): The crystal structure of PGIP (polygalacturonase-inhibiting protein), a leucine-rich repeat protein involved in plant defense. Proc. Nat. Acad. Sci. 100: 10124-10128.

32. Donald, T. M., Pellerone, F., Adam-Blondon, A. F., Bouquet, A., Thomas, M. R., Dry, I. B. (2002): Identification of resistance gene analogs linked to a powdery mildew resistance locus in grapevine. Theor. Appl. Genet., 104: 610-618.

33. Dondini, L., Costa, F., Tataranni G., Tartarini, S., Sansavini, S. (2004): Cloning of apricot RGAs (Resistance Gene Analogs) and development of molecular markers associated with Sharka (PPV) resistance. J. Hort. Sci. Biotechn., 79: 729-734.

34. Evert R. F. (2006): Esau's plant anatomy. Wiley \& Sons, Inc., Hoboken, New Jersey 3rd edition. 76-82.

35. Faize, M., Sugiyama, T., Faize, L., Ishii H. (2003): Polygalacturonase-inhibiting protein (PGIP) from Japanese pear: possible involvement in resistance against scab. Physiol. Mol. Plant. Path., 63: 319-327.

36. Federici, L., Di Matteo, A., Fernandez-Recio, J., Tsernoglou, D., Cervone, F. (2006): Polygalacturonase inhibiting proteins: players in plant innate immunity? Trends. Plant. Sci. 11: 65-70.

37. Ferrari, S., Vairo, D., Ausubel, M., Cervone, F., De Lorenzo, G. (2003): Tandemly duplicated Arabidopsis genes that encode polygalacturonase-inhibiting proteins are regulated coordinately by different signal transduction pathways in response to fungal infection. The Plant Cell, 15: 93-106.

38. Fielding, A., H. (1981): Natural inhibitors of fungal polygalacturonases in infected fruit tissues. J. Gen. Microbiology, 123: 377-381.

39. Fisher, M. L., Anderson, A. J., Albersheim, P. (1973): A single plant protein efficiently inhibits endopolygalacturonases secreted by Colletotrichum lindemuthianum and Aspergillus niger. Plant Physiol., 51: 489-491.

40. Flor, H. H. (1955): Host-parasite interaction in flax rust - its genetics and other implications. Phytopathol., 45: 680-685.

41. Gardiner, S. E., Bus, V. G. N., Rusholme, R. L., Chagné, D., Rikkerink, E. H. A. (2007): Apple In: Kole C, eds. Genome Mapping and Molecular Breeding in Plants, Volume 4 Fruits and Nut. Springer-Verlag Berlin Heidelberg, 1-53.

42. Gentzbittel, L., Mouzeyar, S., Badaoui, S., Mestries, E., Vear, F., DeLabrouhe, D. T., Nicolas, P. (1998): Cloning of molecular markers for disease resistance in sunflower, Helianthus annus L. Theor. Appl. Genet., 96: 519-525.

43. Ghuysen, J. M. (1968): Use of bacteriolytic enzymes in determination of wall structure and their role in cell metabolism. Bacteriol. Rev. 32: 425-464.

44. Glits M. (2000): Gyümölcsfák betegségei. In: Glits M., Folk Gy. Kertészeti növénykórtan. 3. átdolgozott kiadás. Mezőgazda Kiadó. Budapest. 210. 
45. Goodstein, M., Shu, S., Howson, R., Neupane, R., Hayes, R. D., Fazo, J., Mitros, T., Dirks, M., Hellsten, U., Putnam, N., Rokhsar, D. S. (2012): Phytozome: a comparative platform for green plant genomics. Nucleic. Acids Res., 40 :1178-1186.

46. Govers, F., Angenent, G. C. (2010): Fertility goddesses as trojan horses. Science, 330: 922-923.

47. Gulcan, R., Misirli, A., Demir, T. (1999): A research on resistance of 'Hacihaliloglu' apricot variety against Monilinia (Sclerotinia laxa Aderh et Ruhl) through cross pollination. Acta Hort., (ISHS) 488: 675-677.

48. Halász, J. (2007): A Kajszi önmeddőségét meghatározó S-allél-rendszer molekuláris háttere. Doktori (PhD) Értekezés, Budapesti Corvinus Egyetem, Budapest.

49. Hayes, A., J., Saghai Maroof, M., A. (2000) : Targeted resistance gene mapping in soybean using modified AFLPs. Theor. Appl. Genet. 100: 1279-1283.

50. Hilwig, M., S., Liu, X., Liu, G., Thornburg, R. W., MacIntosh G. C. (2010): Petunia nectar proteins have ribonuclease activity. J. Exp. Bot. 6 : 2951-2965.

51. Harada, Y., Nakao, S., Sasaki, M., Sasaki, Y., Ichihashi, Y., Sano, T. (2004): Monilia mumecola, a new brown rot fungus on Prunus mume in Japan. J. Gen. Plant Pathol., 70: 297-307.

52. Honey, E. E. (1936) North American species of Monilinia. Occurrence, grouping and life-histories. Am. J. Bot., 23: 100-106.

52. Holb, I. J. (2003): The brown rot fungi of fruit crops (Monilinia spp.) I. Important features of their biology. (Review), Int. J. Hort. Sci., 4: 23-36.

53. Hugot, K., Ponchet, M., Marais, A., Ricci, P., Galiana, E. (2002): A tobacco S-like RNase inhibits hyphal elongation of plant pathogens. Mol. Plant Microbe Interact.15(3): 243-250.

54. International Rice Genome Sequencing Project (2005): The map-based sequence of the rice genome. Nature 436: 793-800.

55. Jakucs, E., Vajna, L. (2003): A gombák ökológiájának általános kérdései. In: Jakucs E., Vajna, L. (szerk.). Mikológia. Bp. Agroinform K. 239-244.

56. Jallion, O., Aury, J. M., Noel, B., Policriti, A., Clepet, C., és mts. (2007): The grapevine genome sequence suggests ancestral hexaploidization in major angiosperm phyla. Nature, 449: 463-467.

57. Jones, J. D. G., Dangl, J. L. (2006): The plant immune system. Nature, 444: 323-328.

58. Jones, T. M., Anderson A. J., Albersheim, P. (1971): Host-pathogen interactions. IV. Studies on the polysaccharide-degrading enzymes secreted by Fusarium oxysporum $f$. sp. lycopersici. Physiol. Plant Pathol., 2: 153-166.

59. Joobeur, T., King, J., Nolin, J., Thomas, E., Dean, R. (2004): The fusarium wilt resistance locus Fom-2 of melon contains a single resistance gene with complex features. Plant J., 39: 283-297

60. Joubert, D., A, Kars, I, Wagemakers, L., Bergmann, C., Kemp, G., Vivier, M. A., van Kan, J. A. L. (2007): A polygalacturonase-inhibiting protein from grapevine reduces the symptoms of the endopolygalacturonase BcPG2 from Botrytis cinerea in Nicotiana benthamiana leaves without any evidence for in vitro interaction. Mol. Plant Microbe Interact. 20: 392-402. 
61. Kajava, A. V. (1998): Structural Diversity of Leucine-rich Repeat Proteins. J. Mol. Biol. 277: 519-527.

62. Kanazin, V., Marek, L. F., Shoemaker, R. C. (1996): Resistance gene analogs are conserved and clustered in soybean. Proc Natl Acad Sci, 93: 11746-11750.

63. Karr, A., L., Albersheim, P. (1970): Polysaccharide-degrading enzymes are unable to attack plant cell walls without prior action by a "wall-modifying enzyme". Plant Physiol. 46: 69-80.

64. Kerekes, L. (1930): A köd. Növényvédelem, 4: 117-118

65. Kessler, A. S., Shimosato-Asano, H., Keinath, N. F., Wuest, S., Ingram, G., Panstruga, R., Grossniklaus, U. (2010): Conserved molecular components for pollen tube reception and fungal invasion. Science 330: 968-971.

66. Kobe, B., Deisenhofer, J. (1995): Proteins with leucine-rich repeats. Curr. Opin. Struct. Biol., 5: 409-16.

67. Komar-Tyomnaya, L., D., Richter, A., A. (2000): Wild species and distant hybrids of apricot are the sources of resistance to Monilia laxa and high content of biologicallyactive substances in fruits. Acta Hort., (ISHS) 538: 147-150.

68. Kövics, Gy. (2000): Növénybetegségeket okozó gombák névtára. Budapest: Mezőgazda Kiadó. 81., 158.

69. Lalli, D. A., Decroocq, V., Blenda, A. V., Schurdi-Levraud, V., Garay, L., Le Gall, O., Damsteegt, V., Reighard, G. L., Abbott, A. G. (2005): Identification and mapping of resistance gene analogs (RGAs) in Prunus: a resistance map for Prunus. Theor. Appl. Genet, 111: 1504-1513.

70. Leckie, F., Mattei, B., Capodicasa, C., Hemmings, A., Nuss, L., Aracri, B., De Lorenzo, G., Cervone F. (1999): The specificity of polygalacturonase-inhibiting protein (PGIP): a single amino acid substitution in the solvent-exposed b-strand/b-turn region of the leucine-rich repeats (LRRs) confers a new recognition capability. EMBO, 18:9 2352-2363.

71. Leister, D., Kurth, J., Laurie, D., A., Yano, M., Sasaki, T., Devos, K.,Graner, A., Schulze-Lefert, P. (1998): Rapid reorganization of resistance gene homologues in cereal genomes. Proc. Natl. Acad. Sci., 95: 370-375.

72. Leister, D. (2004): Tandem and segmental gene duplication and recombination in the evolution of plant disease resistence genes. Trend. Genet., 20: 116-122.

73. McHale, L., Tan, X., Koehl, P., Michelmore, R. W. (2006): Plant NBS-LRR proteins: adaptable guards. Genome Biol., 7: 212-222.

74. McNeill, J., Turland, J. N. (2011): Major changes to the code of nomenclature. Melbourne, July 2011. Taxon 60: 1495-1497.

75. Mehlenbacher, S., Cociu,V., Hough, L. F. (1990): Apricot (Prunus). Acta Hort. 290: 65-110.

76. Meyers, B. C., Dickerman, A. W., Michelmore, R. W., Sivaramakrishnan, S., Sobral, B. W., Young, N. D. (1999): Plant disease resistance genes encode members of an ancient and diverse protein family within the nucleotide-binding superfamily. Plant J., 20: $317-332$. 
77. Ngugi, H. K., Sherm, H. (2004): Pollen mimicry during infection of blueberry flowers by conidia of Monilinia vaccinii-corymbos. Physiol. Mol. Plant. Path. 3: 113-123.

78. Nicotra, A., Conte, L., Moser, L., Fantechi, P., Barbagiovani, I. (2006): Breeding programme for Monilia laxa (Aderh. \& Ruhl.) Resistance on apricot. Acta Hort., (ISHS) 701: 307-311.

79. Oliveira, M. B., Nascimento L. B., Junior, M. L., Petrofeza, S. (2010): Characterization of the dry bean polygalacturonase-inhibiting protein (PGIP) gene family during Sclerotinia sclerotiorum (Sclerotiniaceae) infection. Genet. Mol. Res., 2: 994-1004.

80. Patthy L. (2007):. Protein evolution. 59-62. Oxford, UK: Blackwell.

81. Pedryc, A. (2003): A kajszi nemesítése. 53-84. In: Pénzes B., Szalai L. Kajszi. Mezőgazda Kiadó, Budapest.

82. Penuela, S., Danesh, D.,Young, N. D. (2002): Targeted isolation, sequence analysis, and physical mapping of nonTIR NBS-LRR genes in soybean. Theor. Appl. Genet., 104: 261-272.

83. Powell, A., Van Kan J., Have A. T., Visser J., Greve L. C., Bennett A. B., Labavitch J. M. (2000): Transgenic expression of pear PGIP in tomato limits fungal colonization. Mol. Plant. Microbe Interact., 13: 942-50.

84. Qiang, X., Xiaopeng, W., Xiuxin, D. (2007): Phylogenetic and evolutionary analysis of NBS-encoding genes in Rosaceae fruit cops. Mol. Phylogenet. Evol., 44: 315-324.

85. Reisch, B., J., Pratt, C. (1996): Grapes, In: Janick J, Moore JN (eds) Fruit Breeding. Vol II. Vine and small fruit. Wiley, New York USA, 297-369.

86. Rozsnyay, Zs. (2001): Megyfajták monilia ellenállósága. Kertészet és Szőlészet, 5152: 15 .

87. Samuelian, S., K., Baldo, A. M., Pattison, J. A., Weber, C. A. (2008): Isolation and linkage mapping of NBS-LRR resistance gene analogs in red raspberry (Rubus idaeus L.) and classification among Rosaceae NBS-LRR genes. Tree Genet. Genomes, 4: 881-896.

88. Schumacher, J., Randles, J. W. (1983): A two-dimensional electrophoretic technique for the detection of circular viroids and virusoids. Anal. Biochem., 135: 288-295.

89. Schrauwen, J., Linskens, H. F. (1972): Ribonucleases in styles. Planta 102: 277-285.

90. Shen, K. A., Meyers, B. C., Nurul Islam-Faridi, M., Chin, D. B., Stelly, D. M., Michelmore, R. W. (1998): Resistance gene candidates identified by PCR with degenerate oligonucleotide primers map to clusters of resistance genes in lettuce. Mol. Plant Microbe Interact., 11: 815-823.

91. Simons, G., Groenendijk, J., Wijbrandi, J., Reijans, M., Groenen, J., Diergaarde, P., Van der Lee, T., Bleeker, M., Onstenk, J., de Both, M., Haring, M., Mes, J., Cornelissen, B., Zabeau, M. Vos Dissection, P. (1998): Dissection of the fusarium I2 gene cluster in tomato reveals six homologs and one active gene copy. Plant Cell, 6: $1055-1068$.

92. Soriano, J. M., Vilanova, S., Romero, C., Llácer, G., Badenes, M. L. (2005): Characterization and mapping of NBS-LRR resistance gene analogs in apricot (Prunus armeniaca L.). Theor. Appl. Genet., 110: 980-989. 
93. StatSoft, Inc., Tulsa OK (2007): STATISTICA (data analysis software system), Version 8., www.statsoft.com.

94. Stotz, H., Contos, J., Powell, A., Bennett, A., Labavitch, J. (1994): Structure of an inhibitor of fungal ploygalcturonase from tomato. Plant Mol. Biol., 25:4 607-617.

95. Stotz, H., Powell, A. L. T., Damon, S. E., Greve, L. C., Bennett, A. B., Labavitch J. (1993): Molecular characterization of a polygalacturonase inhibitor from Pyrus communis L. cv. Bartlett. Plant Physiol., 102: 133-138.

97. Surányi, D. (2003): A kajszi jelentősége, termesztésének története és helyzete. In: Pénzes B. és Szalay L (szerk.). Kajszi. Bp. Mezőgazda Kiadó 11-29.

98. Szügyi, S., Rozsnyai, Zs., Apostol, J. (2012). Betegségellenálló meggyhibridek jellemzése. Agrofórum 43: 28-31.

99. Tamura, K., Peterson, D., Peterson, N., Stecher, G., Nei, M., Kumar, S. (2011): MEGA5: Molecular Evolutionary Genetics Analysis using Maximum Likelihood, Evolutionary Distance, and Maximum Parsimony Methods. Mol. Biol. Evol, 28: 2731-2739.

100. Thompson, J. D., Higgins, D. G., Gibson, T. J. (1994): CLUSTAL W: Improving the sensitivity of progressive multiple sequence alignment through sequence weighting, positions-specific gap penalties and weight matrix choice. Nucleic Acids Res., 22: 4673-4680.

101. Toubart, P., Desiderio, A., Salvi, G., Cervone, F., Daroda, L., De Lorenzo, G. (1992): Cloning and characterization of the gene encoding the endopolygalacturonaseinhibiting protein (PGIP) of Phaseolus vulgaris L.. Plant J, 2: 367-73.

102. Tuskan, G. A., Difazio, S., Jansson, S., Bohlmann, J., Grigoriev, I., és mts. (2006): The genome of black cottonwood, Populus trichocarpa. Science, 313: 1596-1604.

103. Tzonev, R., Yamaguchi, M. (1999): Resistance in some Prunus species in Japan against blossom blight, caused by Monilinia laxa (Ehr.): Prunus armeniaca var. ansu Maxim., Prunus armeniaca L., Prunus mume Sieb. et Zucc. and interspecific hybrids among Prunus species. Acta Hort., (ISHS) 488: 649-654.

104. Tzoneva, E. and Tzonev, R. (1999): Blossom blight caused by Monilinia laxa (Ehr.) A conception on infection mechanism. Acta Hort. (ISHS) 488: 711-714.

105. Velasco, R. mts. (2010): The genome of the domesticated apple (Malus $\times$ domestica Borkh.). Nature Genetics, 10: 833-839

106. Velasco, R és mts. (2007): A High Quality Draft Consensus Sequence of the Genome of a Heterozygous Grapevine Variety. PLoS ONE, 12: e1326.

107. Vilanova, S., Romero, C., Abbott, A. G., Llácer, G., Badenes, M. L. (2003): An apricot (Prunus armeniaca L.) F2 progeny linkage map based on SSR and AFLP markers, mapping plum pox virus resistance and self-incompatibility traits. Theor. Appl. Genet., 107: 239-247.

108. Walker-Simmons, M., Hadwiger, L., Ryan, C., A. (1983): Chitosans and pectic polysaccharides both induce the accumulation of the antifungal phytoalexin pisatin in pea pods and antinutrient proteinase inhibitors in tomato leaves. Biochem. Biophys. Res. Commun. 110: 194-199 
109. Wan, C. Y., Wilkins, T. A. (1994): A modified hot borate method significantly enhances the yield of high-quality RNA from cotton (Gossypium hirsutum L.). Anal. Biochem., 223: 7-12.

110. Weaver, L. O. (1950): Effect of temperature and relative humidity on occurence of blossom blight of stone fruits. Phytophatol., 40: 1136-1153.

111. Wood, R. (1960): Pectic and cellulolytic enzymes in plant diseases. A. Rev. Plant Physiol. 11: 299-309.

112. Vuylsteke, M., Peleman, J. D., Michiel, J. T., Van Eijk, M. J. T. (2007): AFLP-based transcript profiling (cDNA-AFLP) for genome-wide expression analysis. Nature Prot., 6: 1401-1413.

113. Xiao, S. (2006): Current Perspectives on Molecular Mechanisms of Plant Disease Resistance.. A. Jaime and T. da Silva (szerk.), Floriculture, Ornamental and Plant Biotechnology, Global Science Books, UK p. 317-333.

114. Yang, S., Zhang, X., Jue, J. W., Tian, D., Chen, J. Q. (2008): Recent duplications dominate NBS-encoding gene expansion in two woody species. Mol. Genet. Genomics, 208: 187-198.

115. Yao, C., Conway, W., Ren, R., Smith, D., Ross, G.,Sams, C. E. (1999): Gene encoding polygalacturonase inhibitor in apple fruit is developmentally regulated and activated by wounding and fungal infection. Plant Mol. Biol., 39: 1231-1241.

116. Zhou, T., Wang, Y., Chen, J. Q., Araki, H., Jing, Z., Jiang, K., Shen, J., Tian, D. (2004): Genome-wide identification of NBS genes in rice reveals significant expansion of divergent non-TIR NBS genes. Mol. Gen. Genomics, 271: 402-415.

117.Zubini, P. (2008): Variaton in peach fruit susceptibility to Monilinia laxa and gene expression. Phd disertation, University of Bologna 


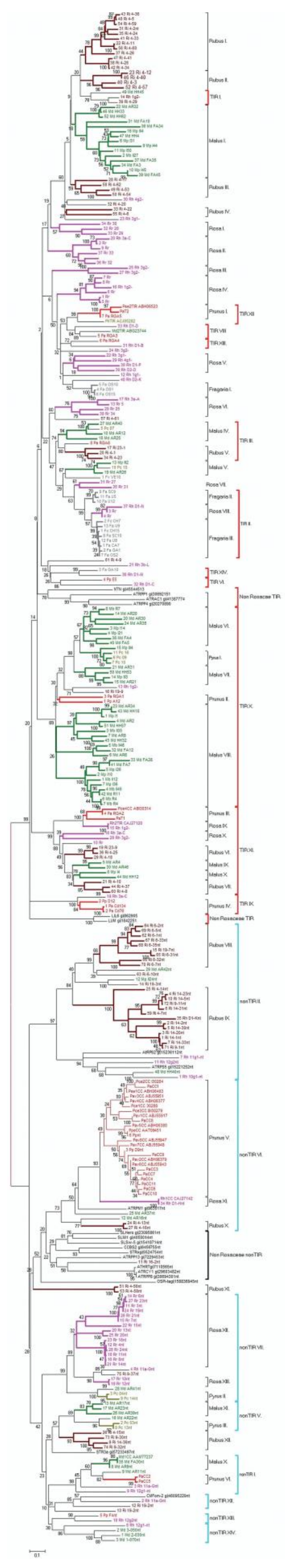




\section{Melléklet}

A filogenetikai törzsfa 327 NBS domén következtetett aminosav szekvenciájának illesztése Neighbor-Joining eljárás alapján. A törzsfán szereplő szekvenciák: általunk meghatározott 13 kajszi RGA szekvencia, Samuelian és mts. (2008) által összegyüjtött 293 Rosacecae családból származó szekvencia, és 21 annotált $\mathrm{R}$ gén különböző növényfajokból. Az egy nemzetségből származó csoportokat külön számmal és a nemzetség nevével jelöltük. Az ágak végén nagyobb mint $70 \%$ bootstrap értékkel rendelkező csoportokat, TIR illetve nonTIR (syn CC) és római számmal jelöltük. A ágak színei a következő nemzetségeket jelölik: barna- Rubus, piros - Prunus, szürke - Fragaria, narancs - Pyrus, zöld - Malus, rózsaszín - Rosa, fekete - nem Rosaceae fajok. 